\title{
Design Features of the Radioactive Liquid-Fed Ceramic Melter System
}

June 1985

Prepared for the U.S. Department of Energy under Contract DE-AC06-76RLO 1830

Pacific Northwest Laboratory Operated for the U.S. Department of Energy by Battelle Memorial Institute 


\title{
DISCLAIMER
}

This report was prepared as an account of work sponsored by an agency of the United States Government. Neither the United States Government nor any agency thereof, nor any of their employees, makes any warranty, express or implied, or assumes any legal liability or responsibility for the accuracy, completeness, or usefulness of any information, apparatus, product, or process disclosed, or represents that its use would not infringe privately owned rights. Reference herein to any specific commercial product, process, or service by trade name, trademark, manufacturer, or otherwise, does not necessarily constitute or imply its endorsement, recommendation, or favoring by the United States Government or any agency thereof. The views and opinions of authors expressed herein do not necessarily state or reflect those of the United States Government or any agency thereof.

\author{
PACIFIC NORTHWEST LABORATORY \\ operated by \\ BATTELLE \\ for the \\ UNITED STATES DEPARTMENT OF ENERGY \\ under Contract DE-AC06-76RLO 1830
}

\begin{tabular}{|c|c|}
\hline \multicolumn{2}{|c|}{$\begin{array}{c}\text { Printed in the United States of America } \\
\text { Available from } \\
\text { National Technical Information Service } \\
\text { United States Department of Commerce } \\
5285 \text { Port Royal Road } \\
\text { Springfield, Virginia } 22161\end{array}$} \\
\hline \multicolumn{2}{|c|}{$\begin{array}{l}\text { NTIS Price Codes } \\
\text { Microfiche A01 }\end{array}$} \\
\hline \multicolumn{2}{|c|}{ Printed Copy } \\
\hline Pages & $\begin{array}{l}\text { Price } \\
\text { Codes }\end{array}$ \\
\hline 001-025 & A02 \\
\hline 026-050 & $\mathrm{A} 03$ \\
\hline 051-075 & A04 \\
\hline $076-100$ & A05 \\
\hline $101-125$ & $A 06$ \\
\hline $126-150$ & A07 \\
\hline $151-175$ & $A 08$ \\
\hline $176-200$ & 109 \\
\hline $201-225$ & $A 010$ \\
\hline $226-250$ & A011 \\
\hline $251-275$ & A012 \\
\hline $276-300$ & A013 \\
\hline
\end{tabular}


OESIGN FEATURES OF THE RADIOACTIVE LIQUID-FED CERAMIC MELTER SYSTEM

Compiled by L. K. Holton, Jr. Major Contributors:

D. N. Berger

R. D. Dierks

P. J. Hof

S. M. Barnes

R. M. Jones

R. A. Brouns

N. L. Scharnhorst

R. M. Gale

G. J. Sevigny

R. W. Goles

O. H. Siemens

R. W. Goles

J. H. Westsik, Jr.

RLFCM Manager: W. J. Bjorklund

June 1985

Prepared for

the U.S. Department of Energy

under Contract DE-ACO6-76RLO 1830

Pacific Northwest Laboratory

Richland, Washington 99352 


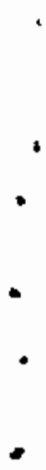

$\mathbf{n}$

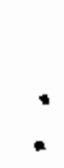

. 


\section{ACKNOWLEDGEMENTS}

The authors acknowledge the valuable contributions made by PNL's Design Drafting Section in the preparation of the design drawings for the Radioactive Liquid-Fed Ceramic Melter (RLFCM). Specifically, the authors appreciate the valuable assistance of the following designers: J. J. Hofweber, K. E. Keene, M. G. Studd, M. D. Ripplinger, A. N. Van Dan, and D. J. Yeager. The authors also acknowledge the invaluable assistance provided by $E$. G. Holmes and $H$. $H$. Irby, Sr. of Basin Design Services in the preparation of instrument and electrical drawings. The invaluable assistance of Naomi Sherer and Minnie Sue Anderton, which lead to the generation of this report, is greatly appreciated. 

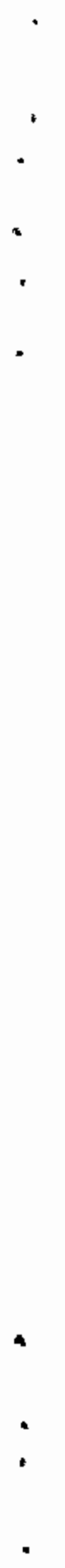
During 1983, the Pacific Northwest Laboratory (PNL), at the request of the Departnent of Energy (DOE), undertook a program with the principal objective of testing the Liquid-Fed Ceramic Meiter (LFCM) process in actual radioactive operations. This activity, termed the Radioactive LFCM (RLFCM) Operations is being conducted in existing shielded hot-cell facilities in B-Cell of the 324 Building, 300 Area, located at Hanford, Washington. This report summarizes the design features of the RLFCM system.

The equipment scope for the RLFCM was defined by examining the minimum requirements necessary to provide a testing facility that would contribute to the commercial application of the LFCM technology. This basic criteria required that the RLFCM include both equipment and process-related objectives. In addition, the equipment system would be integrated with and substituted for a waste solidification system, which was used in previous projects (NWVP 1979, WSEP 1972). To support the vitrification system, new equipment systems that were added included a waste blending and storage rack, a waste feeding system, the LFCM, a canister handling turntable, and an off-gas treatment system. These equipment systems were integrated with existing cell equipment consisting of condensate treatment and secondary off-gas treatment to form the RLFCM system.

The principal testing objective of the RLFCM is to verify the LFCM process as a viable method for converting high-level nuclear waste to borosilicate glass. This will require that the borosilicate glass produced from the RLFCM meet minimum performance criteria for acceptance as part of a licensed waste disposal system when produced within a range of anticipated process conditions. Specific objectives which were considered in the completion of the equipment design include:

- verify remote operation, process control, and maintenance of the RLFCM and support equipment

- determine the reliability of the RLFCM process and equipment systems in a radioactive environment 
- characterize the emission abatement performance of the RLFCM off-gas treatment system

- develop a process and equipment performance data base for remote operation of the RLFCM and production of borosilicate glass

This report describes the major design features of the RLFCM system.

These features include:

- a waste preparation and feed system which uses pulse-agitated waste preparation tanks for waste slurry agitation and an air displacement slurry pump for transferring waste slurries to the LFCM

- a waste vitrification system (LFCM)--the design features, design approach, and reasoning for the design of the LFCM are described

- a canister-handling turntable for positioning canisters underneath the RLFCM discharge port

- a ganala source positioning and detection system for monitoring the glass fill level of the product canisters.

- a primary off-gas treatment system for removing the majority of the radionuclide contamination from the RLFCM off gas. 


\section{CONTENTS}

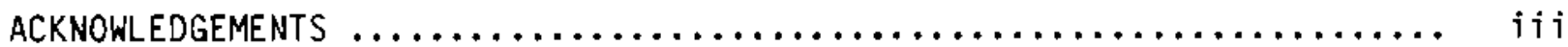

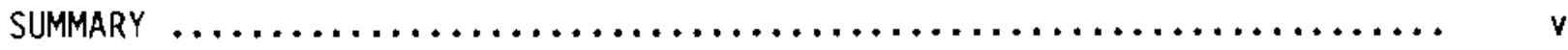

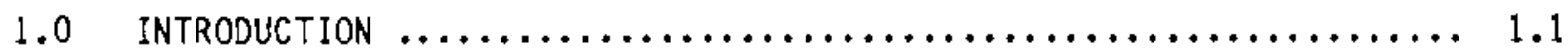

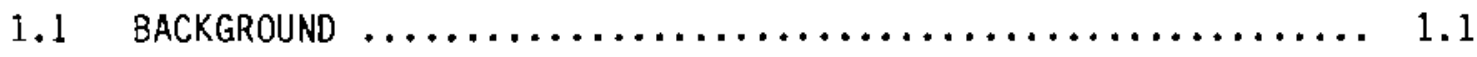

1.2 OBJECTIVES OF THE RADIOACTIVE LFCM $\ldots \ldots \ldots \ldots \ldots \ldots \ldots \ldots, 1.2$

2.0 DESIGN REQUIREMENTS AND OBJECTIVES $\ldots \ldots \ldots \ldots \ldots \ldots \ldots \ldots \ldots \ldots, 2.1$

2.1 FUNCTIONAL REQUIREMENTS $\ldots \ldots \ldots \ldots \ldots \ldots \ldots \ldots \ldots \ldots \ldots \ldots \ldots \ldots \ldots \ldots \ldots, 2.1$

2.2 EQUIPMENT DESIGN REQUIREMENTS $\ldots \ldots \ldots \ldots \ldots \ldots \ldots \ldots \ldots \ldots \ldots \ldots \ldots \ldots \ldots$

2.3 DESIGN AND FABRICATION CODES AND STANDARDS $\ldots \ldots \ldots \ldots \ldots \ldots, 2.4$

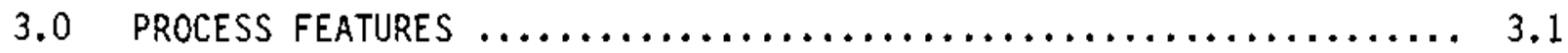

3.1 PROCESS SYSTEM DESCRIPTION $\ldots \ldots \ldots \ldots \ldots \ldots \ldots \ldots \ldots \ldots \ldots \ldots \ldots \ldots \ldots \ldots .1$

3.2 WASTE PREPARATION SYSTEM $\ldots \ldots \ldots \ldots \ldots \ldots \ldots \ldots \ldots \ldots \ldots \ldots \ldots \ldots \ldots \ldots, 3.7$

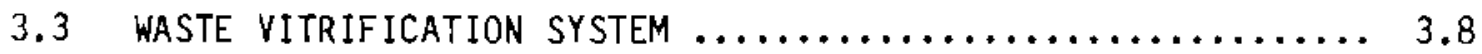

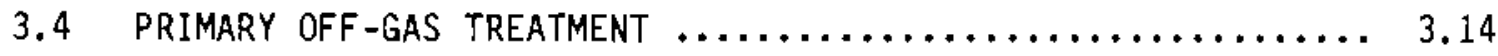

4.0 FACILITY AND EQUiPMENT DESIGN FEATURES $\ldots \ldots \ldots \ldots \ldots \ldots \ldots \ldots, 4.1$

4.1 SHIELDED CELL FACILITIES $\ldots \ldots \ldots \ldots \ldots \ldots \ldots \ldots \ldots \ldots \ldots, 4.1$

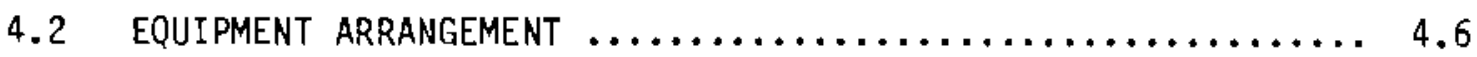

4.2.1 Equipment Rack Concept $\ldots \ldots \ldots \ldots \ldots \ldots \ldots \ldots \ldots, 4.6$

4.2.2 Equipment Layout in B-Cell ................ 4.10

4.3 WASTE PREPARATION AND fEed SYSTEM $\ldots \ldots \ldots \ldots \ldots \ldots \ldots \ldots \ldots, 4.11$

4.3.1 Waste Preparation Tank Design and Operation ....... 4.11

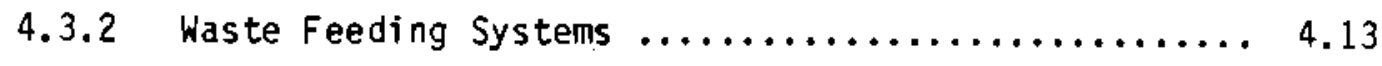


4.4 RADIOACTIVE LIQUID-FED CERAMIC MELTER (RLFCM) $\ldots \ldots \ldots \ldots \ldots 4.15$

4.4.1 RLFCM Design Description ................ 4.15

4.4 .1 .1 Function $\ldots \ldots \ldots \ldots \ldots \ldots \ldots \ldots \ldots \ldots \ldots .4 .15$

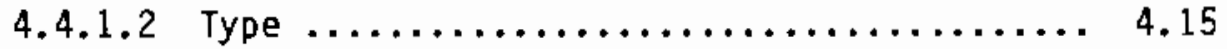

4.4 .1 .3 Configuration $\ldots \ldots \ldots \ldots \ldots \ldots \ldots \ldots \ldots .16$

4.4.1.4 Containment Vessel $\ldots \ldots \ldots \ldots \ldots \ldots \ldots \ldots . . \ldots 46$

4.4 .1 .5 Melter Tank .................. 4.17

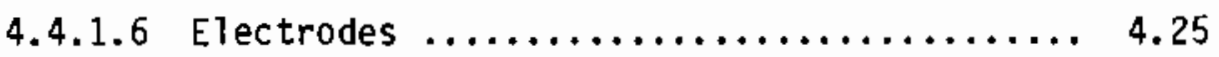

4.4.1.7 Electrode Power Connector .......... 4.28

4.4.1.8 Discharge Throat ............... 4.30

4.4.1.9 Discharge Trough ............... 4.31

4.4.1.10 Discharge Section ................ 4.31

4.4 .2 Melter Thermal Design ................... 4.34

4.4.2.1 Refractory Arrangement ............ 4.34

4.4.2.2 Melter Cooling Requirements .......... 4.35

4.4.2.3 Predicted Thermal Behavior .......... 4.36

4.4.2.4 Back wall and Floor of the Meiter ...... 4.36

4.4 .2 .5 Melter Lid $\ldots \ldots \ldots \ldots \ldots \ldots \ldots \ldots \ldots \ldots \ldots 4.37$

4.4.2.6 Electrodes and the Electrode Wall ...... 4.39

4.4 .2 .7 Discharge Section Cooling ........... 4.40

4.4.3 Electrical System Design ................. 4.41

4.4.3.1 Melting Cavity Dimensions ........... 4.41

4.4.3.2 Electrical Power System Sizing ........ 4.42

4.4.4 RLFCM Operation and Control ............. 4.46

4.5 CANISTER-HANDLING TURnTABLE $\ldots \ldots \ldots \ldots \ldots \ldots \ldots \ldots \ldots \ldots \ldots \ldots \ldots$

4.5 .1 Turntable Design Description ............. 4.48 
4.5.2 Turntable/Melter Seals $. . . \ldots \ldots \ldots \ldots \ldots \ldots \ldots \ldots, 4.50$

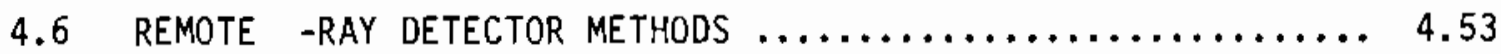

4.6.1 Glass Levei Detection System ................ 4.53

4.6.2 Canister Positioning Systern .................. 4.58

4.7 VITRIFICATION OFF -GAS TREATMENT SYSTEM $\ldots \ldots \ldots \ldots \ldots \ldots \ldots .4 .59$

4.7.1 Primary Off-Gas Scrubber System ............... 4.59

4.7.1.1 Ejector Venturi Scrubber System ......... 4.60

4.7.1.2 Quench Scrubber (TK-111) ............ 4.62

4.7.1.3 Steam Jet and Condenser ............ 4.63

4.7.2 Vacuum Control for the RLFCM $\ldots \ldots \ldots \ldots \ldots \ldots \ldots . . .6 .64$

4.7.3 Secondary Off-Gas Treatment System $\ldots \ldots \ldots \ldots \ldots \ldots .6 .65$

4.7.3.1 Evaporator $(T K-113) \ldots \ldots \ldots \ldots \ldots \ldots \ldots, 4.65$

4.7.3.2 Acid Fractionator (TK-115) ........... 4.65

4.7.3.3 Process Off-Gas Scrubber $(T K-118) \ldots \ldots .4 .66$

4.8 PROCESS CONTROL AND DATA ACQUISITION SYSTEM $\ldots \ldots \ldots \ldots \ldots, 4.66$

4.9 CANISTERS, CANISTER HANDLING GRAPPLE, AND CANISTER
LID WELDING $\ldots \ldots \ldots \ldots \ldots \ldots \ldots \ldots \ldots \ldots \ldots \ldots \ldots \ldots \ldots \ldots \ldots \ldots \ldots \ldots \ldots \ldots \ldots \ldots \ldots \ldots \ldots$

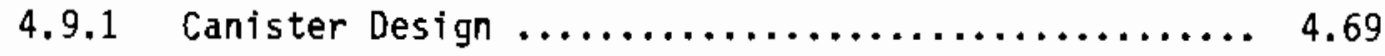

4.9.2 Canister Handling Grapple .................. 4.70

4.9.3 Canister Lid Welder $\ldots \ldots \ldots \ldots \ldots \ldots \ldots \ldots \ldots, 4.72$

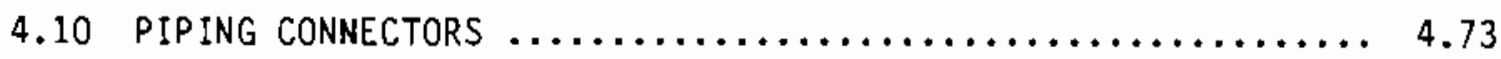

4.10.1 Block Connectors ......................... 4.75

4.10 .2 PUREX Connector $\ldots \ldots \ldots \ldots \ldots \ldots \ldots \ldots \ldots \ldots \ldots \ldots \ldots \ldots \ldots \ldots \ldots, 4.78$

4.10.3 Hanford Remote Flange $\ldots \ldots \ldots \ldots \ldots \ldots \ldots \ldots \ldots . . .4 .79$

4.10 .4 Modified Pipe Flange $\ldots \ldots \ldots \ldots \ldots \ldots \ldots \ldots \ldots, 4.80$

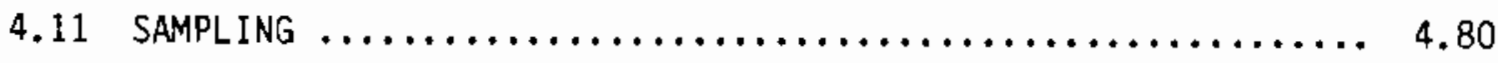


4.11 .1 Liquid Sampling $. \ldots \ldots \ldots \ldots \ldots \ldots \ldots \ldots \ldots \ldots, 4.80$

4.11.2 Molten Glass Sampling $\ldots \ldots \ldots \ldots \ldots \ldots \ldots \ldots \ldots, 4.81$

4.11 .3 Off-Gas System Sampling $\ldots \ldots \ldots \ldots \ldots \ldots \ldots \ldots \ldots, 4.83$

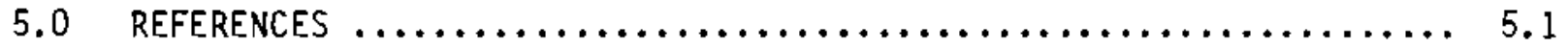

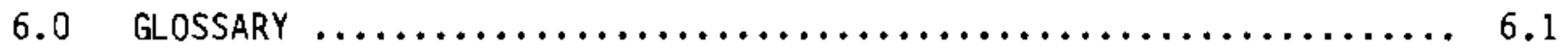




\section{FIGURES}

3.1 Simplified Flow Diagram of the Radioactive Liquid-Fed Ceramic

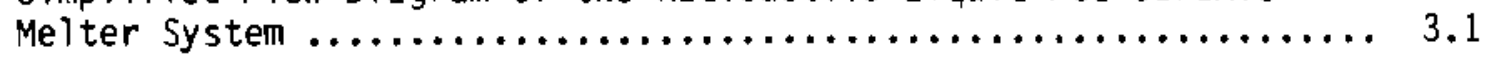

3.2 Components of the Off-Gas Treatment System $\ldots \ldots \ldots \ldots \ldots \ldots \ldots, 3.2$

3.3 Simplified Engineering Flow Diagram of the Waste Preparation and Waste Vitrification System $\ldots \ldots \ldots \ldots \ldots \ldots \ldots \ldots \ldots \ldots \ldots \ldots \ldots, 3.4$

3.4 Cutaway View of the Canister Handling Turntable $\ldots \ldots \ldots \ldots \ldots \ldots, 3.5$

3.5 Canister Handling Turntables Shown with Melter Before Testing .... 3.6

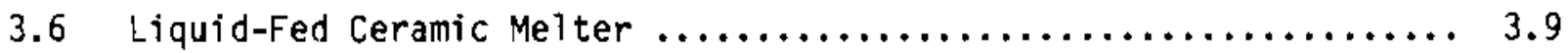

4.1 Plan View of the First Floor of the 324 Building $\ldots \ldots \ldots \ldots \ldots . .4 .2$

4.2 Isometric View of the Radiochemical Engineering Cells $\ldots \ldots \ldots \ldots$...

4.3 Elevation View of the $B$-Cell Equipment Arrangement $\ldots \ldots \ldots \ldots \ldots$. 4.4

4.4 Equipment Rack 2A Photographed Before Placement in

the Shielded Cell ...................................... 4.7

4.5 PTan View of the Radiochemical LFCM Pilot Plant Equipment

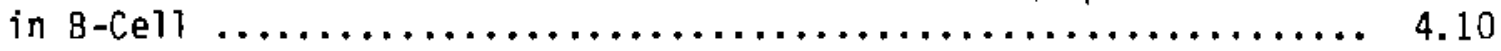

4.6 Waste Preparation System Rack and Detail of Pulse-Agitated

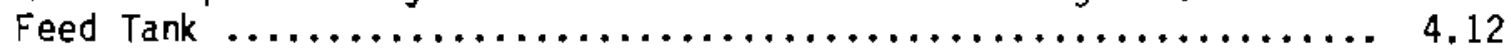

4.7 Air-Displacement Pump $\ldots \ldots \ldots \ldots \ldots \ldots \ldots \ldots \ldots \ldots \ldots \ldots \ldots \ldots \ldots \ldots \ldots \ldots \ldots \ldots, 14$

4.8 Lengthwise Vertical Section of the RLFCM $\ldots \ldots \ldots \ldots \ldots \ldots \ldots \ldots .18$

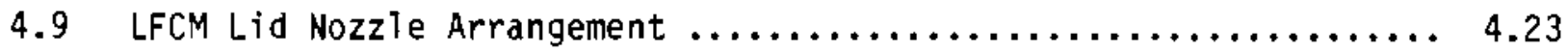

4.10 Melter Electrode $\ldots \ldots \ldots \ldots \ldots \ldots \ldots \ldots \ldots \ldots \ldots \ldots \ldots \ldots \ldots, 4.26$

4.11 Electrode Power Cable Connector $\ldots \ldots \ldots \ldots \ldots \ldots \ldots \ldots \ldots \ldots \ldots, 4.29$

4.12 Submerged Throat Block and Riser Probe $\ldots \ldots \ldots \ldots \ldots \ldots \ldots \ldots, 4.30$

4.13 Discharge Cone and Handling Equipment $\ldots \ldots \ldots \ldots \ldots \ldots \ldots \ldots, 4.33$

4.14 Centerline Computer-Predicted Temperature Profiles for the
Back Wall and Floor of the Melter ........................... 4.38

4.15 Predicted Temperature Profiles for the Electrode Walls ........ 4.38 
4.16 Power Supply for the RLFCM Electrodes $\ldots \ldots \ldots \ldots \ldots \ldots \ldots \ldots \ldots, 4.42$

4.17500 Amp SCR/200 kVA Transformer Electrical Characteristics ...... 4.44

4.18 Process Control System for the RLFCM $\ldots \ldots \ldots \ldots \ldots \ldots \ldots \ldots, 4.47$

4.19 Canister Turntable Partially Assembled ..................... 4.49

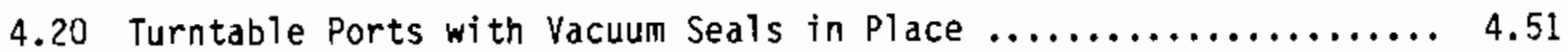

4.21 Positions of the Access Port on the Turntable $\ldots \ldots \ldots \ldots \ldots \ldots . .642$

4.22 Metal Seal Concept for Connection of the RLFCM to the Canister

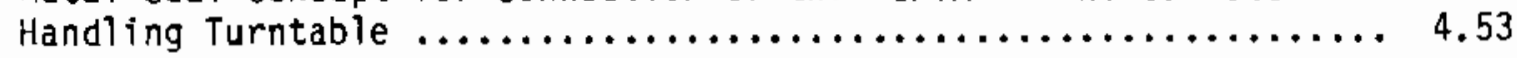

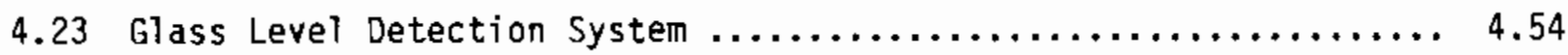

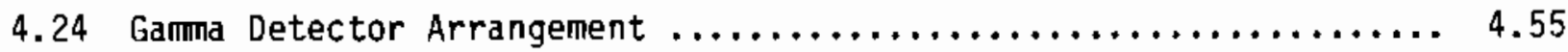

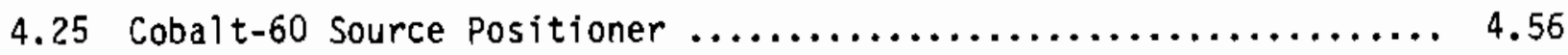

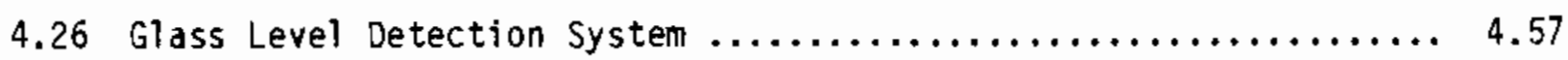

4.27 Process Control and Data Acquisition Systems $\ldots \ldots \ldots \ldots \ldots \ldots \ldots .67$

4.28 Console for the Microprocessor-Based Control System $\ldots \ldots \ldots \ldots \ldots 4.68$

4.29 Reference Canister for the Radioactive RLFCM Pilot Plant ....... 4.70

4.30 Canister Handling Grapple Concept $\ldots \ldots \ldots \ldots \ldots \ldots \ldots \ldots \ldots \ldots, 4.71$

4.31 Concept of GTA Fusion welder for Canister Closure $\ldots \ldots \ldots \ldots \ldots .7 .73$

4.32 Block Connectors $\ldots \ldots \ldots \ldots \ldots \ldots \ldots \ldots \ldots \ldots \ldots \ldots \ldots \ldots \ldots, 4.76$

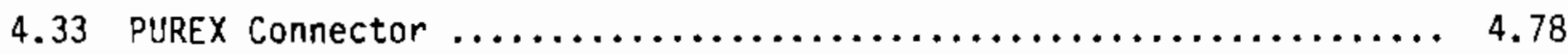

4.34 Liquid Waste Sampler Assembly $\ldots \ldots \ldots \ldots \ldots \ldots \ldots \ldots \ldots \ldots \ldots, 4.81$

4.35 Molten Glass Sampler Assembly $\ldots \ldots \ldots \ldots \ldots \ldots \ldots \ldots \ldots \ldots \ldots, 4.82$

4.36 Mass Spectrometer and Associated Control Instrumentation ....... 4.84

4.37 RLFCM Noncondensable Gas Analyses System Components $\ldots \ldots \ldots \ldots \ldots 4.85$

4.38 Components for the RLFCM off-Gas Sample Control System ......... 4.87

4.39 Typical Aerosol Collection Device $\ldots \ldots \ldots \ldots \ldots \ldots \ldots \ldots \ldots \ldots . . .68$

4.40 Four-Stage Aerosol Size Classification Device $\ldots \ldots \ldots \ldots \ldots \ldots . . . .4 .69$ 


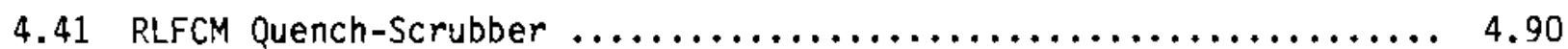

4.42 Effluent Scrubber for Cold Stream Sampling .............. 4.91 


\section{TABLES}

4.1 Equipment Racks and Function $\ldots \ldots \ldots \ldots \ldots \ldots \ldots \ldots \ldots \ldots \ldots$

4.2 Refractory Configuration of the Floor and Back Wall of the Melter ...................................... 4.37

4.3 Anticipated off-Gas Conditions Leaving the RLFCM $\ldots \ldots \ldots \ldots \ldots . \ldots 40$

4.4 Desired Piping Connector Features for the Radioactive LFCM ...... 4.74

4.5 Overall Dimensions of Block Connectors Jsed in the RLFCM ...... 4.77

4.6 Melter Effluents $\ldots \ldots \ldots \ldots \ldots \ldots \ldots \ldots \ldots \ldots \ldots \ldots \ldots \ldots \ldots \ldots \ldots \ldots$ 


\subsection{INTRODUCTIDN}

This report describes the design features of the Radioactive Liquid-Fed Ceramic Melter (RLFCM) system, which is one component of Pacific Northwest Laboratory's (PNL) Nuclear Waste Treatment Program (NWTP). The objective of the RLFCM is to test the operation of the liquid-fed ceramic melter process under radioactive operating conditions. The pilot-scale equipment is located within existing shielded facilities on the Ganford site.

\subsection{BACKGROUND}

Since 1975, the LFCM vitrification process has been under development and testing in the United States. The early success of the process as a method to produce borosilicate glass from simulated high-level wastes ( $H L W$ ), its inherent simplicity and its ease of operation and maintenance led to its adoption as a process option for immobilizing high-level nuclear wastes in borosilicate glass. Currently, the LFCM is the Department of Energy's (DOE) reference vitrification process for defense and commercial nuclear waste solidification demonstrations. The DDE projects in which the LFCM is the reference HLW vitrification process include:

- West Valley Demonstration Project (WVDP)

- Defense Waste Processing Facility (DWPF), and

- Hanford Waste Vitrification Project (HWVP),

Because the LFCM was adopted as the reference waste solidification process in the U.S., the DOE requested that PNL design, construct, and operate a radioactive pilot-scale waste solidification facility in which to test the LFCM process. Operation of this system would provide development and design data that could be applied to the other DOE projects and future production facilities. The testing of the RLFCM is expected to substantially reduce the technical and financial risks in proceeding with the implementation of the LFCM vitrification process technology. 


\subsection{OBJECTIVES OF THE RADIOACTIVE LFCM}

The principal objective of the RLFCM is to verify waste vitrification as a viable process for inmobilizing high-level nuclear waste in borosilicate glass. To achieve this objective the borosilicate glass produced from the LFCM must meet minimum performance criteria for acceptance in a federally licensed waste disposal system. Verification of the LFCM vitrification process and the borosilicate glass product is necessary as part of a strategy to implement this technology in the commercial and defense fuel cycles. Specific technical objectives of the RLFCM are to:

- verify remote operation, process control, and maintenance of the LFCM

- demonstrate remote design features of the LFCM and support equipment

- determine the reliability of the LFCM process and equipment in a radioactive environment

- verify the emission abatement performance of the LFCM off-gas system

- demonstrate the LFCM facility concept (LFCM, canister turntable, primary off-gas scrub system)

- develop a process and equipment performance data base for remote operation of the LFCM system and for production of borosilicate glass.

- evaluate or verify glass quality suitable for final storage. 


\subsection{DESIGN REQUIREMENTS AND OBJECTIVES}

\subsection{FUNCTIONAL REQUIREMENTS}

The Radioactive LFCM program was defined by examining the minimum requirements necessary to provide a testing facility that would contribute significantly to the application of the LFCM technology. This required that the RLFCM incorporate both process- and equipment-related objectives. It was also realized, however, that integrating the RLFCM equipment components into an existing equipment system would require some compromise in equipment design.

The RLFCM has the necessary equipment features to inmobilize a variety of liquid (and potentially solid) wastes in a borosilicate glass waste form. Typical liquid waste sources will include nonradioacative chemicals spiked with dissolved spent fuel from a light water reactor (LWR), and cesium and strontium fission product concentrates. Typical solid wastes might include contaminated organic and inorganic ion-exchange materials and transuranic (TRU) incinerator ash. Based on these considerations, the following process bases were identified for the RLFCM:

- The RLFCM process was designed to process liquid waste at a maximum theoretical rate of $40 \mathrm{~L} / \mathrm{h}$ corresponding to a practical operating rate of $25 \mathrm{~L} / \mathrm{h}$. This operating liquid feed rate with a feed slurry composition corresponding to 350 to 500 grams glass oxide/L will yield a glass production rate of approximately 9 to $12.5 \mathrm{~kg} / \mathrm{h}$. Favorable feed melting characteristics could allow for higher feed rates and resultant higher glass production rates. The practical 1 iquid waste treatment capacity of $25 \mathrm{~L} / \mathrm{h}$ for the RLFCM was selected based upon several bounding constraints.

-- A smaller capacity RLFCM does not represent larger-capacity systems in terms of melting dynamics, melter operating performance (internal temperature distributions, power consumption, and process performance), and off-gas emission performance.

-- A larger capacity RLFCM would be difficult to install and operate as an integral part of the existing process systems in the 
hot cell. Additional capacity above the $25 \mathrm{~L} / \mathrm{h}$ for the RLFCM is not expected to add significant information on process and equipment performance.

-- The RLFCM process system was designed to represent a reference waste vitrification facility concept; thus, the process system includes a representative waste feeding system, a RLFCM, a canister handling and positioning turntable, and representative equipment for primary off-gas decontamination.

- The RLFCM design is intended to meet applicable DoE operating requirements (DOE Order 5480.1, DOE Order 5481.1, DOE Order 5484.1, DOE Drder 5700 and DOE Order 6430). The process, which is being developed and tested for eventual commercial application, witl be required to meet regulations proposed by the Nuclear Regulatory Commission (NRC), Environmental Protection Agency (EPA), and state or local regulations, which are believed to be similar to these DOE orders. An objective of the RLFCM testing is to show that these regulations can be met.

- The RLFCM process is designed to immobilize a variety of liquid waste types. A reference waste source has been identified that consists of nonradioactive chemicals and radioactive dissolver solution (from spent fuel dissolution), and cesium, and strontium spikes. The process system will be capable of utilizing these waste sources to test a variety of radioactive waste flowsheets.

- The RLFCM process system will incorporate a high degree of instrumentation and sampling capability. This is necessary to establish an optimum approach for control of the process and maximize data obtained. The use of sample analysis and instrumentation witl be used to statistically develop the necessary process performance characteristics to show that an acceptable borosilicate glass product is being produced. This data will be used in conjunction with nondestructive and destructive analyses of the waste form package to develop and verify quality verification approaches. 


\subsection{EQUIPMENT DESIGN REQUIREMENTS}

The RLFCM is installed in an existing radiochemical hot cell in which the process equipment is maintained with the use of overhead cranes and wall mounted masterslave manipulators. The specific equipment arrangement and facility constraints had significant impact on the equipment design. The following general design requirements pertain to the process equipment and equipment racks.

- The design life of key equipment components comprising the RLFCM is at least three years. Equipment components with an anticipated life of less than three years are designed for remote replacement. The RLFCM has been designed with sufficient material corrosion allowances to conservatively operate for three years.

- The process equipment and equipment racks are designed for fully remote (overhead crane) or semiremote (master-slave manipulators) installation and maintenance, depending upon access of the equipment systems to the maintenance systems.

- To achieve the most efficient level of process equipment maintenance, reliable designs were used, where possible, and materials and fabrication were quality controlled; but for equipment that is susceptible to failure, a balance was chosen between temporary or permanent concepts and readily replaceable or redundant, but not necessarily similar, equipment.

- Equipment is designed for maximum reliability and minimum maintenance. High-failure items, such as pumps and valves, were kept to a minimum within the radiochemical processing cells. Agitators, pumps or valves, were placed where they are accessible for remote maintenance.

- The equipment systems were designed to be operationally safe to meet radiochemical safety design requirements. Off-gas cleanup systems are provided that will assure the required decontamination of process off gases. 
- Equipment that could potentially become pressurized is equipped with emergency vent piping through water-filled seal pots or filters.

- At least two means of transferring materials from one tank to another were provided in the event of a malfunction of one route. The two transfer routes are not usually identical.

- Steam- or air-operated jets are used for fluid transfer, wherever possible.

- The "equipment rack" concept is employed to group process equipment and service piping to aid remote installation. The equipment modules are designed to minimize the number of in-cell connections between equipment racks. Where such connections are needed, they are located to provide easy manipulator and cell crane access. All in-cell connectors are designed to provide easy manipulator or crane operation and extended $1 \mathrm{i}$ fe.

- Equipment systems are provided with the necessary features for decontamination.

- The equipment racks, RLFCM and canister handling turntable with associated dunnage, are designed to withstand and remain operational under the forces produced by an operating basis earthquake (OBE) having a maximum force of $0.125 \mathrm{~g}$ and a simultaneous maximum vertical ground acceleration equal to $2 / 3$ of the horizontal. Structures are designed for earthquake forces superimposed on the normal design loads. The design procedure conservatively accounts for the dynamic behavior of the structure during a postulated earthquake.

\subsection{DESIGN AND FABRICATION CODES AND STANDARDS}

The equipment components, which comprise the RLFCM, were designed and fabricated to high standards with strict quality assurance requirements imposed on their manufacturers. The following codes and standards were generally used for the design and fabrication of the equipment components:

- American Society of Mechanical Engineers, Boiler and Pressure Vessel Code, Section VIII, Div. 1. No code stamp is required. 
- ANSI B31.1, American National Standard Code, Power Piping

- AWS D31.1, American Welding Society, Structural Welding

- National Electric Code

- National Electrical Manufacturer's Association standards. 


\subsection{PROCESS FEATURES}

3.1 PROCESS SYSTEM DESCRIPTION

A simplified process flow diagram for the RLFCM, designed to convert highlevel nuclear waste to borosilicate glass, is shown in Figure 3.1. This system is comprised of three basic subsystems:

- waste feed preparation and feeding system

- waste vitrification system

- off-gas and condensate treatment systems.

The majority of the off-gas treatment system components (see Figure 3.2 ) were installed as part of previous programs and are described elsewhere

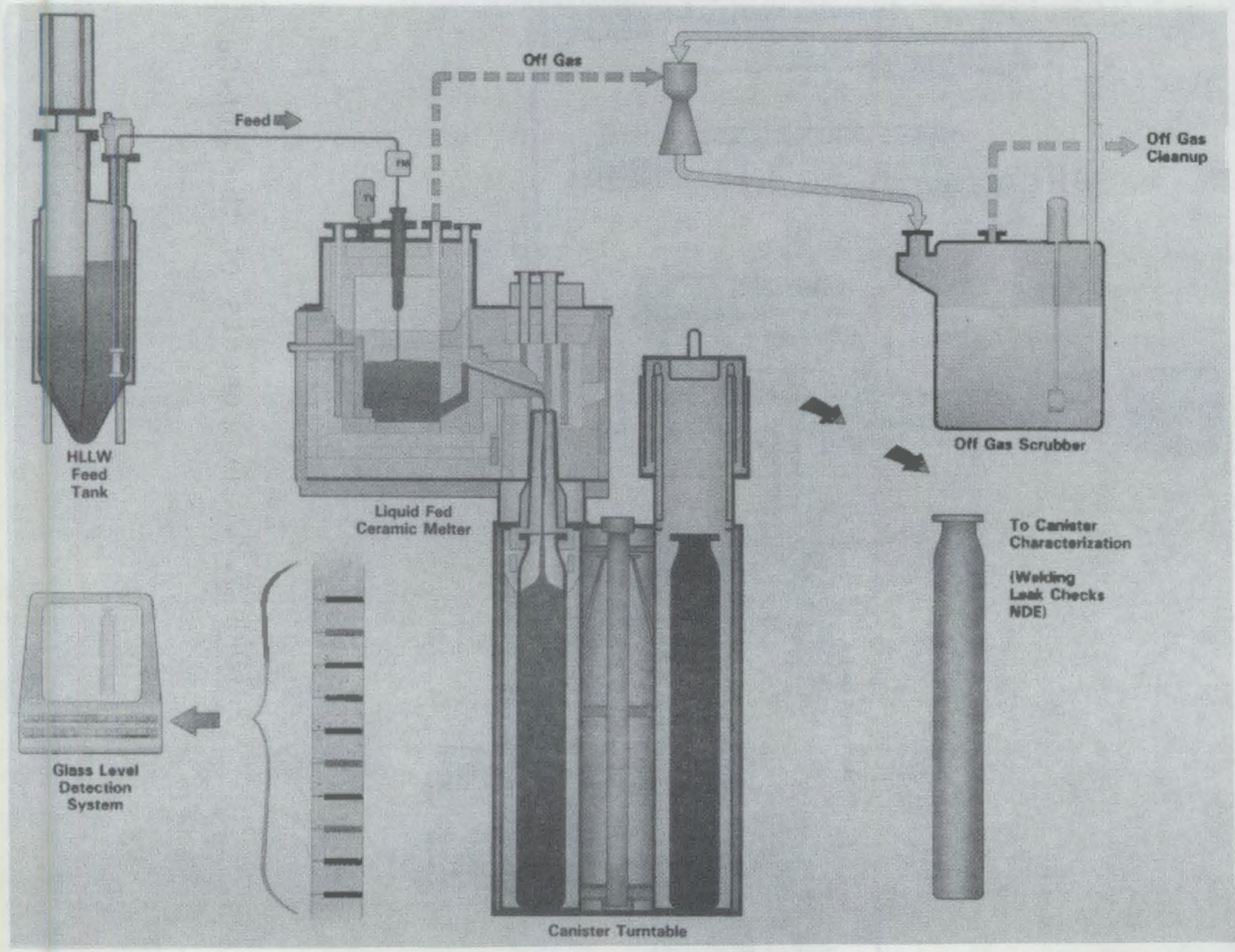

FIGURE 3.1. Simplified Flow Diagram of the Radioactive Liquid-Fed Ceramic Melter System 


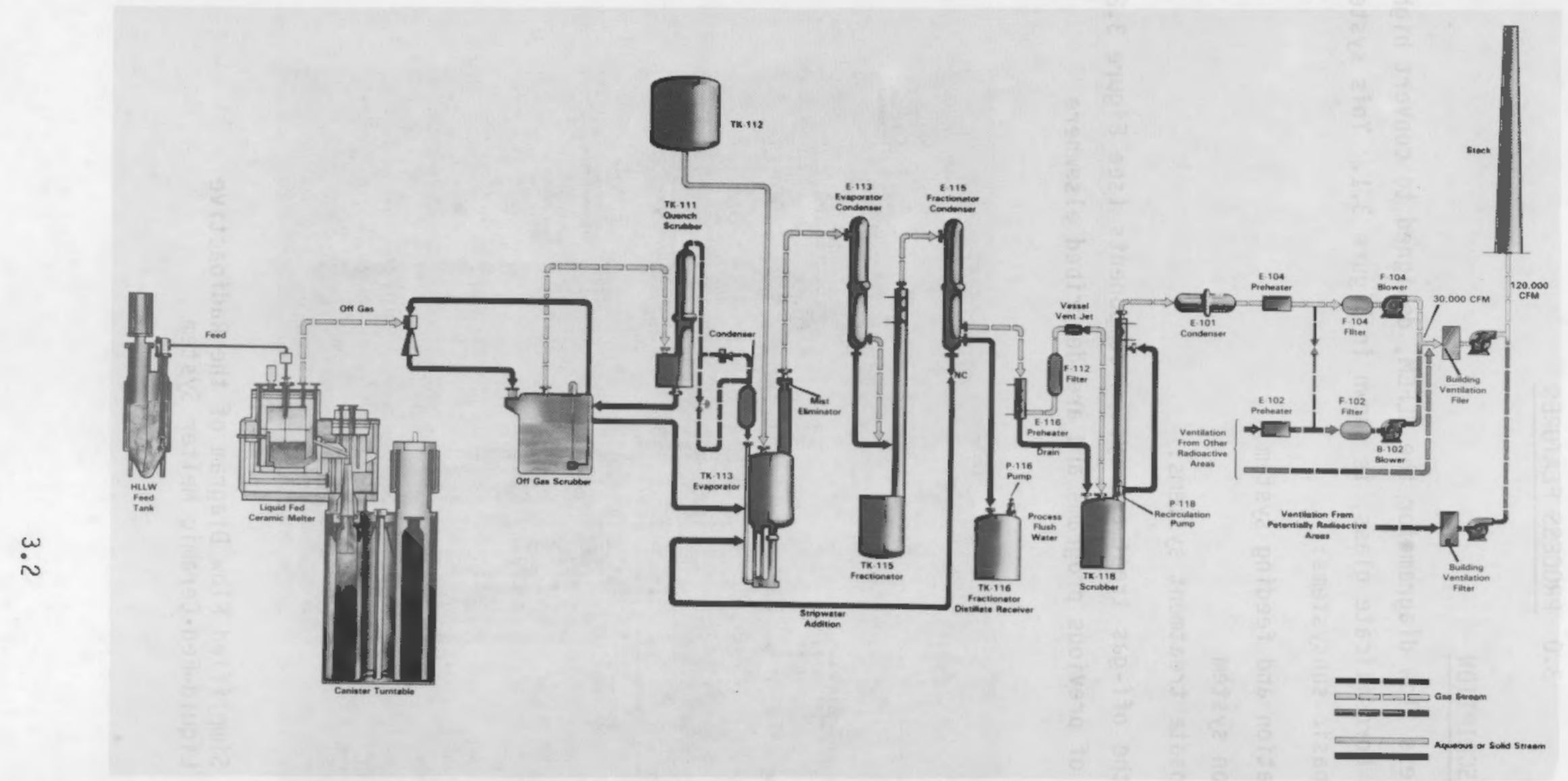

FIGIIRE 3.2. Componerits of the Off-fias Treatment System 
(BNWL-968). The equipment components specifically installed as part of the RLFCM, shown in Figure 3.3, include the waste preparation and feed tanks (TK-130 and TK-131), an air displacement feed pump, RLFCM, canister handling turntable (TK-133), ejector venturi, scrub solution recirculation tank $($ TK-134), and a seal pot (TK-135).

The radioactive waste to be used for extended operations of the RLFCM is composed of nonradioactive chemicals spiked with radioactive material originating primarily from dissolved spent fuel. This waste material will be supplemented with radiocesium and radiostrontium concentrates, when required, and other chemicals to simulate a variety of waste compositions. The adequacy of spent fuel as a radionuclide source has been reviewed based on three factors: 1) resultant chemical composition of the waste glass including fission products, actinides, and nonradioactive chemical additives; 2) glass radioactivity levels, and 3) glass decay heat levels. Based upon this review, chemicals spiked with spent fuel were determined to provide an appropriate alternative to the actual waste from many sources. When high-activity glass or high-heat borosilicate glass are required, additional radiocesium and radiostrontium will be added to the waste and will provide representative chemical and radiochemical compositions for evaluation after vitrification.

The radioactive wastes are fed from the feed makeup tank to the RLFCM using a slurry feed and metering system. In the RLFCM, the liquid waste dries and melts into a vitreous form. Off gas from the vitrification process, which consists of air inleakage, water vapor, chemical decomposition products (e.g., $\mathrm{NO}, \mathrm{NO}_{2}, \mathrm{CO}, \mathrm{CO}_{2}, \mathrm{H}_{2}$ ), entrained particulates and volatile and semivolatile radiochemical contaminates, are treated through successive stages of scrubbing, quenching, filtration, and absorption. The decontaminated off gas is discharged to the building Process Off-Gas (POG) System, and eventually to the building stack.

The molten vitreous product formed in the RLFCM overflows into a stainless steel canister. The waste canister is positioned underneath the RLFCM by a rotating turntable (Figures 3.4 and 3.5 ), which has positions for three canisters. Once filled, the canister is allowed to cool, is capped with a dust 


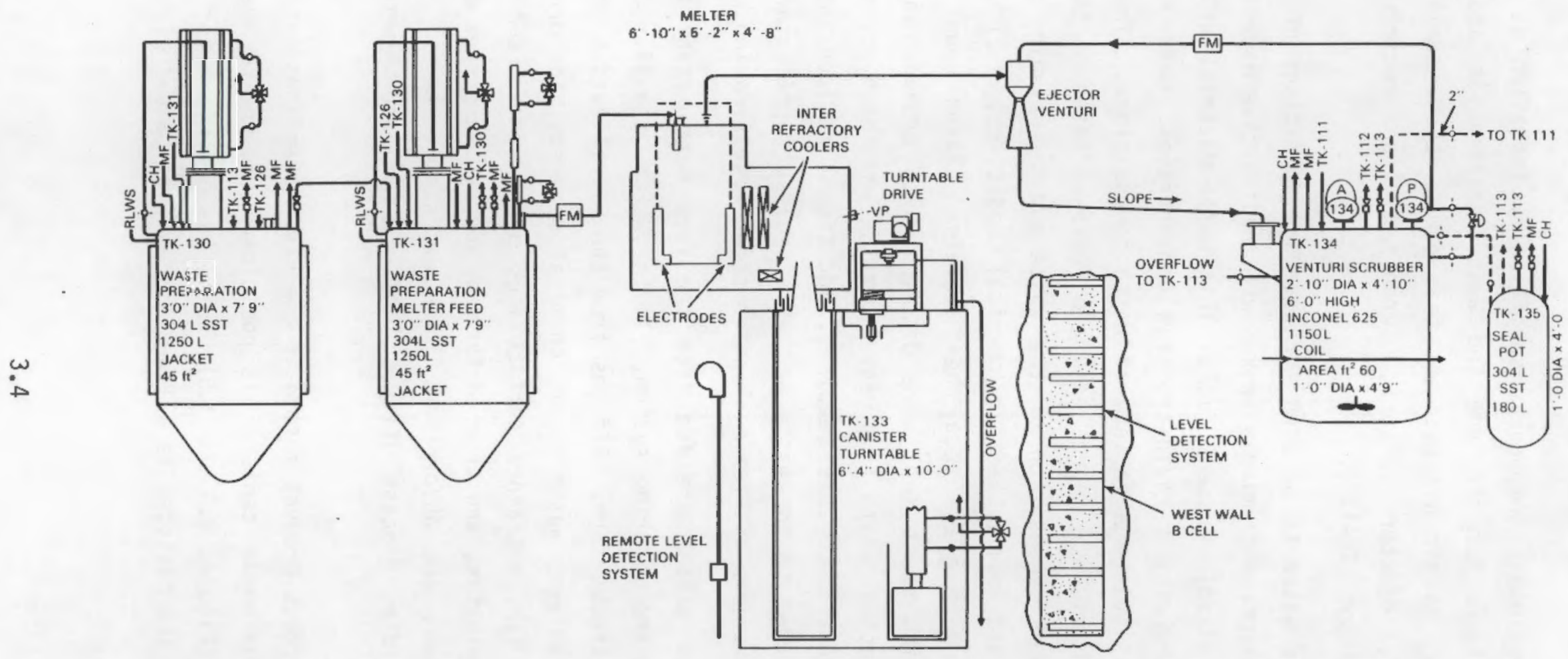

FIGURE 3.3. Simplified Enyineering Flow Diagran of the Waste Preparation and Waste Vitrification System 


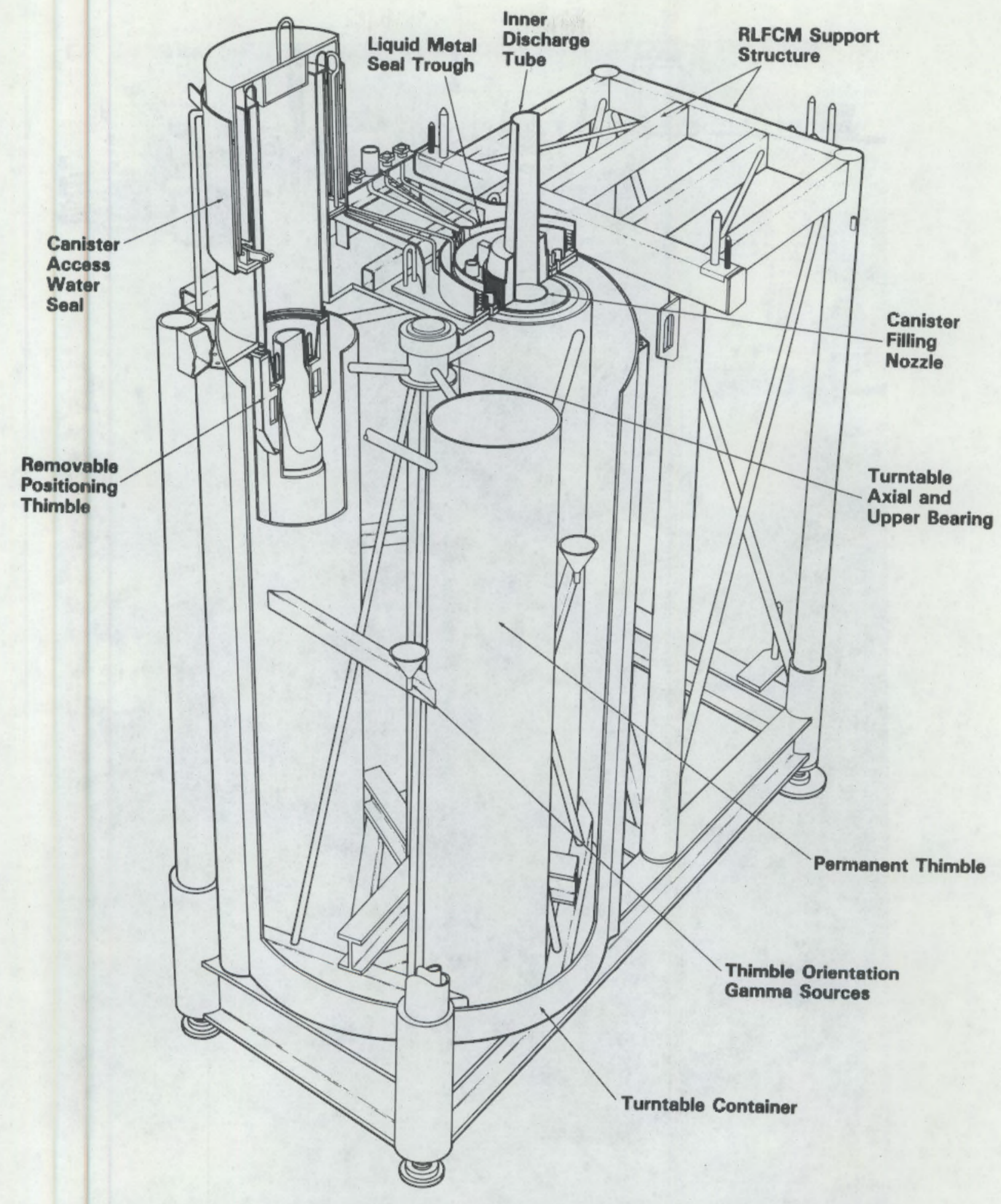

FIGURE 3.4. Cutaway View of the Canister Handling Turntable 


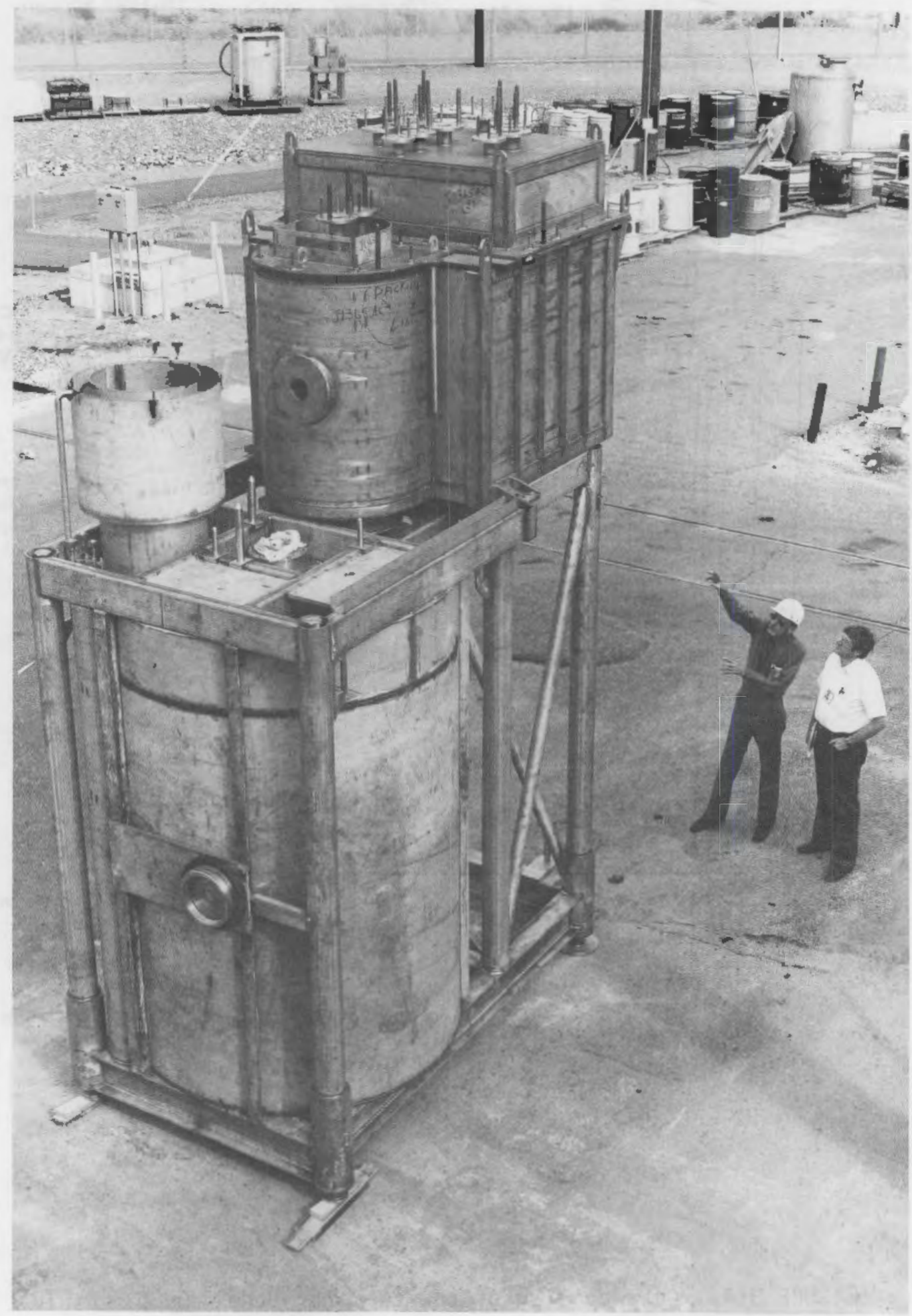

FIGURE 3.5. Canister Handling Turntables Shown with Melter Before Testing 
cover, and is transferred to another part of the process cell for sealing. The canister will be stored and examined in an adjacent shielded processing cell.

Condensates generated from the waste vitrification process are fed continuousiy to the evaporation/fractionation system (TK-113/TK-115), where the radiochemical activity contained in the vitrification condensates is concentrated. The radioactive concentrate (TK-113 bottoms) from the liquid waste treatment system is periodically recycled to the waste feed system. The lowactivity overheads condensate (TK-113 overheads) is fractionated to recover nitric acid. The recovered nitric acid is recycled to the process system or neutralized prior to disposal. The very low activity TK-115 overhead condensate is eventually routed to another facility for disposal.

\subsection{WASTE PREPARATION SYSTEM}

The waste preparation and feed system is comprised of two 1250-L pulseagitated feed tanks and an air-displacement pump used to transfer radioactive slurry to the RLFCM.

A pulse-agitated feed tank, rather than a mechanically agitated feed tank, was chosen for use in the RLFCM because of its greater flexibility and ability to homogenize and suspend solids in HLW slurries.

The pulse-agitation concept is simple. The "agitator" is a 16 in. dia pulse tube with a conical tip reduced to an orifice size of 2 in. A slave piston, with a drive piston located on either side, is positioned above the pulse tube which operates in a cyclic manner. First, the slave piston is withdrawn, pulling $-60 \mathrm{~L}$ of solution into the pulse tube. In a downward stroke, the slave piston pushes $-60 \mathrm{~L}$ of solution out of the pulser tube toward the bottom of the tank. The solution is accelerated as it passes through the conical bottom of the pulser. The shape of the pulser, pulser discharge nozzle, and the bottom of the tank are designed to produce a fluid pulsing motion, propelling the solution upward in the tank turning over the entire tank volume by this displacement, approximately once every three minutes.

The principal advantage of this tank agitation system is the degree of control that can be achieved by varying the pulsing frequency and intensity of 
the agitation. Initially perfected for use in the PAMELA Project, Mol, Belgium, this feed tank system has performed better than mechanically agitated tanks for the homogenization of a wide variation of feeds including both simulated acidic and alkaline waste slurries in tests at PNL.

The waste preparation and feed system tank sizes and dimensions were governed by constraints established by criticality safety, physical placement in the process cell, method of agitation, and system capacity. The waste preparation system was sized to allow for continuous operation of the RLFCM system at a design feed rate capacity of $25 \mathrm{~L} / \mathrm{h}$.

During normal operations, the waste slurries will be prepared in TK-130 and transferred to TK-131 for feeding to the LFCM.

The reference waste feed pump (further described in Section 4.3.1) is an air-displacement pump system. The pump, which is remotely operated, was designed for a limited pumping capacity so that excessive feeding to the RLFCM cannot occur.

\subsection{WASTE VITRIFICATION SYSTEM}

The waste vitrification system is comprised of the RLFCM, a canisterhandling turntable, and a glass-level detection syster. The mechanical aspects of each of these equipment components are discussed in Section $4 . n$.

The slurry-fed, joule-heated glass melter (Figure 3.6) operates on the same basic principle as a large number of commercial electric melters in the glass industry. Molten glass is contained within a cavity made of highly corrosion-resistant, glass-contact refractory. Rehind the glass-contact refractory are additional layers of lower density backup and insulating refractories. These backup materials provide secondary glass containment and added thermal insulation. The glass is joule-heated by passage of an alternating current between electrodes in contact with the molten glass. For the RLFCM melter, the electrodes are composed of a nickel and chromium alloy known as Incone1-690

(3) Inconel-690 is a trade name of the International Nickel Corporation. 


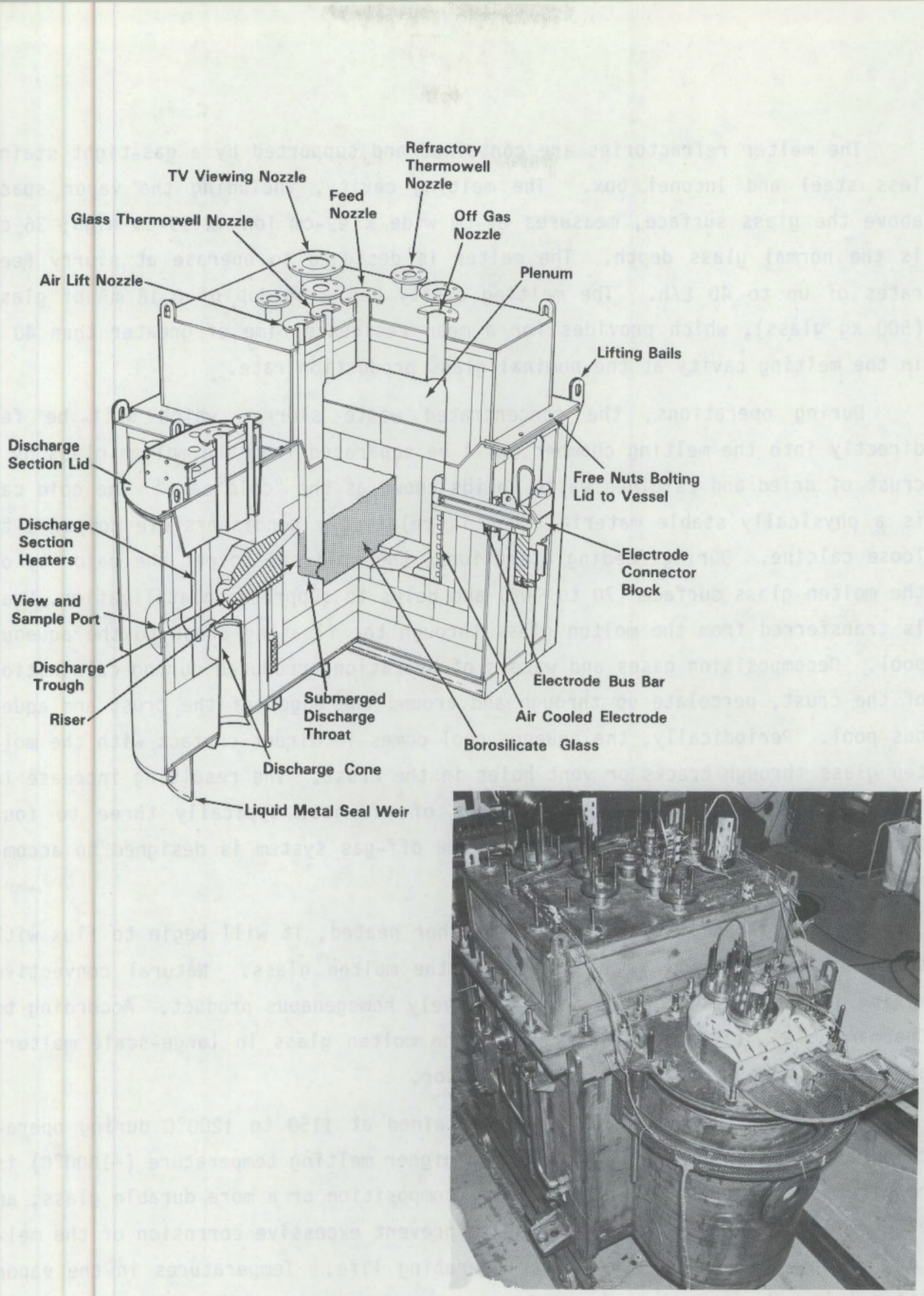

FIGURE 3.6. Liquid-Fed Ceramic Melter 
The melter refractories are contained and supported by a gas-tight stainless steel and Inconel box. The melting cavity, including the vapor space above the glass surface, measures $61-\mathrm{cm}$ wide $\times 99-\mathrm{cm}$ long $\times 99-\mathrm{cm}$ high; $36 \mathrm{~cm}$ is the normal glass depth. The melter is designed to operate at slurry feed rates of up to $40 \mathrm{~L} / \mathrm{h}$. The melting cavity has a holdup of $0.18 \mathrm{~m}^{3}$ of glass (500 kg glass), which provides for a mean residence time of greater than $40 \mathrm{~h}$ in the melting cavity at the nominal glass production rate.

During operations, the concentrated waste slurry, which will be fed directly into the melting chamber, will be separated from the molten glass by a crust of dried and calcined waste solids known as the "cold cap." The cold cap is a physically stable material that is relatively nondispersible compared to loose calcine. During feeding operations, the cold cap covers the majority of the molten glass surface ( 70 to $90 \%$ ) and helps to suppress volatilization. Heat is transferred from the molten glass through the floating crust to the aqueous pool. Decomposition gases and waters of hydration, produced during calcination of the crust, percolate up through and around the edges of the crust and aqueous pool. Periodically, the aqueous pool comes in direct contact with the molten glass through cracks or vent holes in the crust. The resulting increase in heat transfer creates temporary surges of off-gas, typically three to four times the nominal off-gas flow rate. The off-gas system is designed to accommodate these anticipated surges.

As the calcined waste crust is further heated, it will begin to flux with the glass formers and is dissolved in the molten glass. Natural convective mixing in the glass provides a comparatively homogeneous product. According to Chapman et al. (1979), intermixing of the molten glass in large-scale melters approaches that of an ideally-mixed reactor.

The bulk glass temperature is maintained at 1150 to $1200^{\circ} \mathrm{C}$ during operation, and $1050^{\circ} \mathrm{C}$ during idling. When a higher melting temperature $\left(\sim 1300^{\circ} \mathrm{C}\right)$ is required to process an off-normal waste composition or a more durable glass, an electrode air-cooling system is used to prevent excessive corrosion of the melter, which would reduce the melter operating life. Temperatures in the vapor space (plenum) above the melt surface range from 200 to $400^{\circ} \mathrm{C}$ during operation, depending upon the feed rate. 
Molten glass exits the melting cavity through the throat of the discharge section located near the floor of the melting cavity. The molten glass rises up a tunnel in the refractory into a separate overflow chamber where it flows down an Inconel-690 trough into a receiving canister. The overflow chamber is heated by silicon carbide electrical-resistance heaters to prevent the glass from solidifying before it reaches the canister. The overflow heaters are designed to be remotely replaced while the melter is idling because the heaters are expected to last $\sim 1$ year. Glass flow up the refractory tunnel is controlled by an airlift, which is an Inconel-690 tube. The glass pouring process is generally batchwise so that $30-60 \mathrm{~kg}$ quantities can be rapidly transferred to the waste canister.

Although feeding continues during canister changeout, the discharge airlift is not operated, so the glass collects in the melting cavity. Once the canister changeout is completed, the airlift is periodically restarted and the pour rate exceeds the production rate for a short period, until the glass is reduced to the normal operating level. This larger quick flow of molten glass heats the insulated empty canister enough to prevent glass solidification that could cause voids in the can.

An evacuated-canister drain system is planned to provide quick partial drainage of the melter during a scheduled shutdown or an emergency. The canister equipped with a special suction tube is evacuated, and the tube is inserted through the melter lid into the molten glass. A metal or glass plug with a low melting point is installed in the suction tube to maintain the canister vacuum. Once the plug in the suction tube melts, the molten glass in the melter cavity will be pulled into the canister, then air cools a section of the suction tube to form a frozen glass zone that will prevent the glass from escaping the evacuation canister.

The melter will not need to be completely emptied in the event of a power failure because of supplemental heating designed in the vapor space above the glass surface. The supplemental heat for initial startup and restart will be provided by heaters installed in two access ports on the melter lid.

During a normal nonoperating period, power is supplied to the melter to prevent cooling below the liquidus temperature of the glass to prevent 
precipitation of solid phases from the glass. This nonoperating period when power is supplied to the electrodes is termed idling.

The RLFCM and its supporting power system is fully instrumented with thermocouples, power system monitors, level monitors, gas-flow monitors, and a pneumatic transducer to monitor the vacuum in the melter plenum. The instrument signals are fed into process alarms and an automatic control system. Bulk glass temperatures are approximated by monitoring replaceable thermocouples positioned in a thermowell behind the glass contact refractory, and directly by a thermowell placed in the main melting cavity. Electrode temperatures are monitored by replaceable thermocouples located outside the electrodes. The load power to the electrodes is controlled automatically to maintain a constant load resistance, which also indicates the bulk-glass temperature. Periodic manual adjustment of the set point, based on the thermocouple indications, accommodates compositional changes. A constant-resistance control system can also be used that automatically adjusts for changes in the decay heat of the glass and changes in slurry feed rate. The flow rate of cooling air to the electrodes is adjusted to maintain the temperature of the electrodes below $1100^{\circ} \mathrm{C}$; the feed rate to the melter is adjusted to maintain the plenum temperature in the range of 200 to $400^{\circ} \mathrm{C}$. In addition to monitoring the plenum temperatures, the instantaneous off-gas flow rate is continuously monitored to assure a stable cold cap. Experience with off-gas flow behavior monitoring (Goles and Sevigny 1982) has shown that various process upsets can be detected in advance. A replaceable camera can be installed in the melter plenum as a backup means of monitoring the meiting operation.

Experience at PNL (Barnes and Larson 1981) conservatively suggests that a three-year melter lifetime can be expected for the electrodes and refractory. Some components, such as thermowells and overflow heaters, will require replacement more often, so they are designed for simple remote replacement while the melter is idling.

The canisters into which the glass is discharged from the RLFCM are contained in and positioned by the canister handling turntable, shown schematically in Figure 3.4. The turntable holds three canisters up to $40.6 \mathrm{~cm}$ (16 in.) in diameter and a length up to $2.64 \mathrm{~m}$ ( $8 \mathrm{ft}, 8.5 \mathrm{in.})$. By adjusting 
the diameter and length of a removable liner, canisters of lesser dimensions can be accommodated in the turntable. The turntable is designed for limited cooling control of the canister, which can be adjusted by the addition or removal of insulating material from the removable liners.

The turntable has two major access ports that are equipped with seals, which can be remotely made and broken. A metal seal capable of maintaining high positive or negative pressures is used to connect the RLFCM to the turntable. This seal consists of an alloy with a low melting point poured into a trough located on the turntable portion of the seal, on which rests a downcomer weir located on the bottom of the RLFCM containment shell.

A water-sealed lid is used on the turntable port used for canister insertion and removal. During normal operations the lid is in place and maintains a vacuum difference of 12.7 to $25.4 \mathrm{~cm}$ (5 to $10 \mathrm{in.)}$ of $\mathrm{H}_{2} \mathrm{O}$ between the turntable/RLFCM system and the cell atmosphere. During canister changeout, the seal is broken; however, a floating seal is lowered onto the removable thimbles as the seal lid is removed. The coupling of this sealing device and the canister thimble prevents most air inleakage to the vitrification system.

The turntable rotates around a center axis with the top and bottom supported by two permanently sealed bearings. The turntable drive system is an electrically driven motor mounted on top of the turntable. A positive indexing system rotates the turntable to the proper canister filling position. Three unique ${ }^{60} \mathrm{Co}$ sources, located near the permanent canister liners, are used to monitor the position of the turntable.

The glass level in the canister is monitored during glass pouring to prevent canister overfilling. This monitoring is achieved with the use of a gamma source $\left({ }^{60} \mathrm{Co}\right)$ and a series of eleven fixed $\mathrm{NaI}$ scintillation detectors mounted in the cell wall. The ${ }^{60} \mathrm{Co}$ source travels up and down the length of the canister. The gamma beam is attenuated where the glass covers the beam, resulting in a significantly decreased detector response below the glass level. The gamma detection system also has the flexibility to use the ${ }^{137} \mathrm{Cs}$ radioactivity present in the glass to monitor the glass level directly. 


\subsection{PRIMARY OFF-GAS TREATMENT}

A new primary off-gas scrubber rack was installed as part of the RLFCM system. This rack is comprised of an ejector venturi, scrub solution recirculation tank, and seal pot.

The ejector venturi is the first RLFCM off-gas treatment device. Its purpose is to condense $295 \%$ of the steam from the off gas, quench the off gases, and remove $90 \%$ of the particulate contamination having a mean diameter below one micron, and essentially all particulates above one micron mean diameter. At the normal flows anticipated in the RLFCM, the vitrification off gas will be cooled from $350^{\circ} \mathrm{C}$ to $60^{\circ} \mathrm{C}$; in the process, $19 \mathrm{~kg} / \mathrm{h}$ of steam will be removed from the off gas. Cooling water is provided to the ejector at a temperature of $40^{\circ} \mathrm{C}$, a flow rate of $76 \mathrm{~L} / \mathrm{min}$, and a pressure of $80 \mathrm{psig}$. At these operating conditions, a $7.62-\mathrm{cm}$ ( 3 in.) $\mathrm{H}_{2} \mathrm{O}$ draft will be generated across the venturi. off gas from the ejector is further decontaminated in a secondary off-gas treatment system that was left in the cell from previous projects.

The scrub solution tank, which has an active volume of $1700 \mathrm{~L}$, is equipped with a mechanical agitator, a cantilever pump for providing scrub solution to the venturi, a seal pot, and the required instrumentation and services. The seal pot attached to the scrub solution tank provides overpressurization relief for the RLFCM and the scrub solution recirculation tank. 


\subsection{FACILITY AND EQUIPMENT DESIGN FEATURES}

Mechanical features of the facility and equipment systems that comprise the RLFCM system are described in this section. New equipment systems were installed in existing shielded cell facilities. These new equipment systems were integrated with existing equipment systems to provide an integrated testing facility.

\subsection{SHIELDED CELL FACILITIES}

The RLFCM equipment was installed in B-Cell, in the Radiochemical Engineering Facility, located on the Hanford site. The facility is in a building of concrete and steel that is divided into five integrated but separate working areas: 1) the Engineering Development Laboratory (EDL-102), 2) the High-Bay Development Laboratory, 3) the Regulated Engineering Development Laboratory (EDL-146), 4) the Radiochemical Engineering Cells, and 5) the Shielded Materials Facility. The total building floor area is about $7800 \mathrm{~m}^{2}\left(84,000 \mathrm{ft}^{2}\right)$. Figure 4.1 shows a ground level floor plan of the Building.

The four Radiochemical Engineering Cells surround an airlock cell that is located at the junction of the T-shaped complex (Figure 4.2). The airlock functions as a transition zone and ventilation barrier for shielded material movement between external areas and the four processing cells. Studies of almost any type of chemical or mechanical processes with radiation levels up to $10^{6}$ roentgens $/ \mathrm{h}$ are conducted in the cells. The cells and the airlock are lined with stainless steel, and are thus properly equipped for aqueous process work. The ventilation system maintains the cells at a negative pressure with respect to the cell operating galleries and the Cask Handling Area to assist in contamination control.

A-Cell will be used for the storage and non-destructive testing of canisters that will be filled during RLCFM tests. C-Cell and D-Cell are used for experimental testing of spent fuel and radioactive glass samples. B-Cell houses the equipment systems for the RLFCM. 


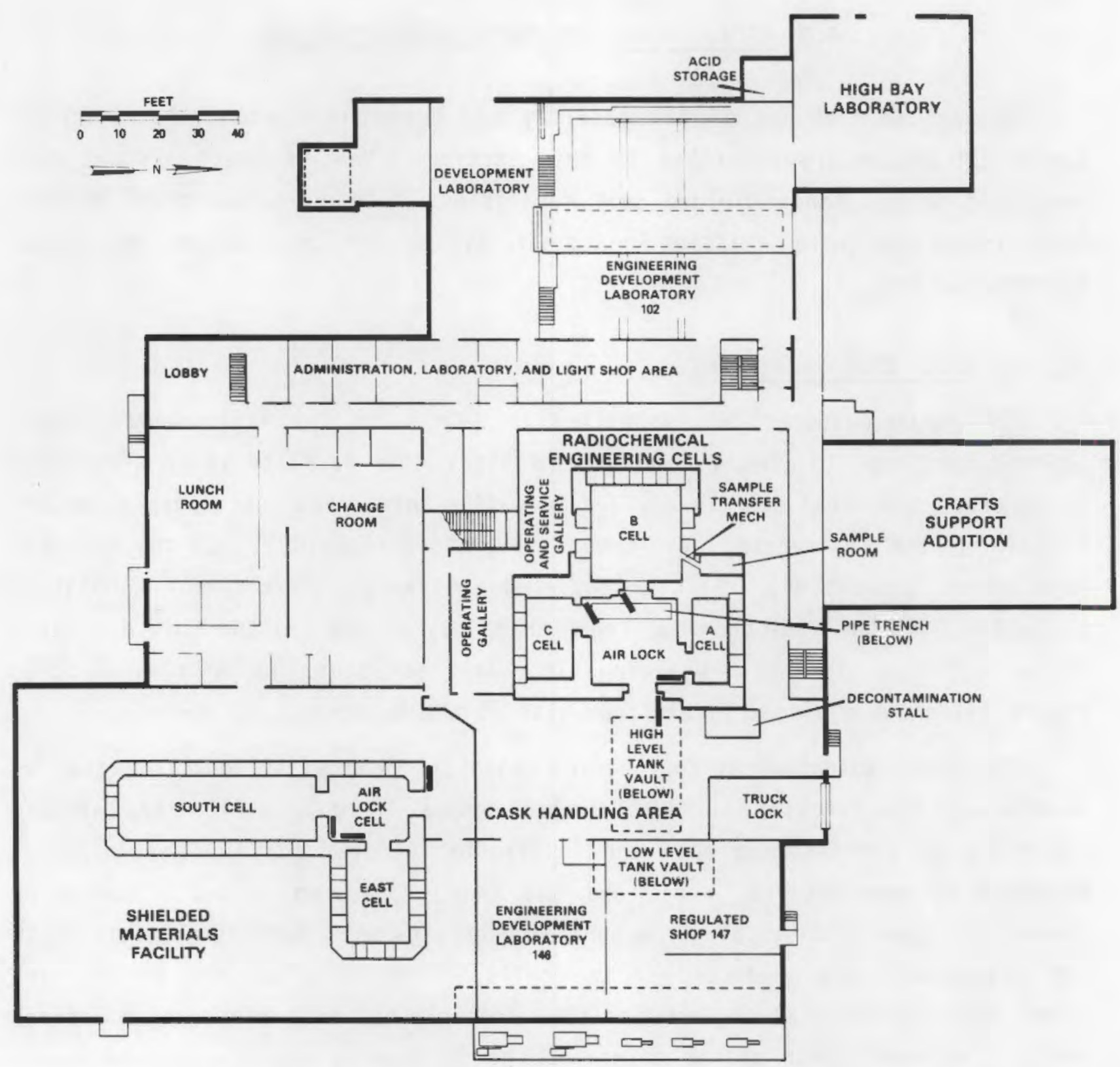

FIGURE 4.1. Plan View of the First Floor of the 324 Building

B-Cell is 7.62-m long, 6.70-m wide, and 9.29-m deep. The cell floor is $3.05 \mathrm{~m}$ below grade. The cell walls are either high-density concrete that are $122-\mathrm{cm}$ thick, or are ordinary concrete that is $137-\mathrm{cm}$ thick, depending on location. Figure 4.3 illustrates the arrangement of various features of the cell. Major cell features include: 


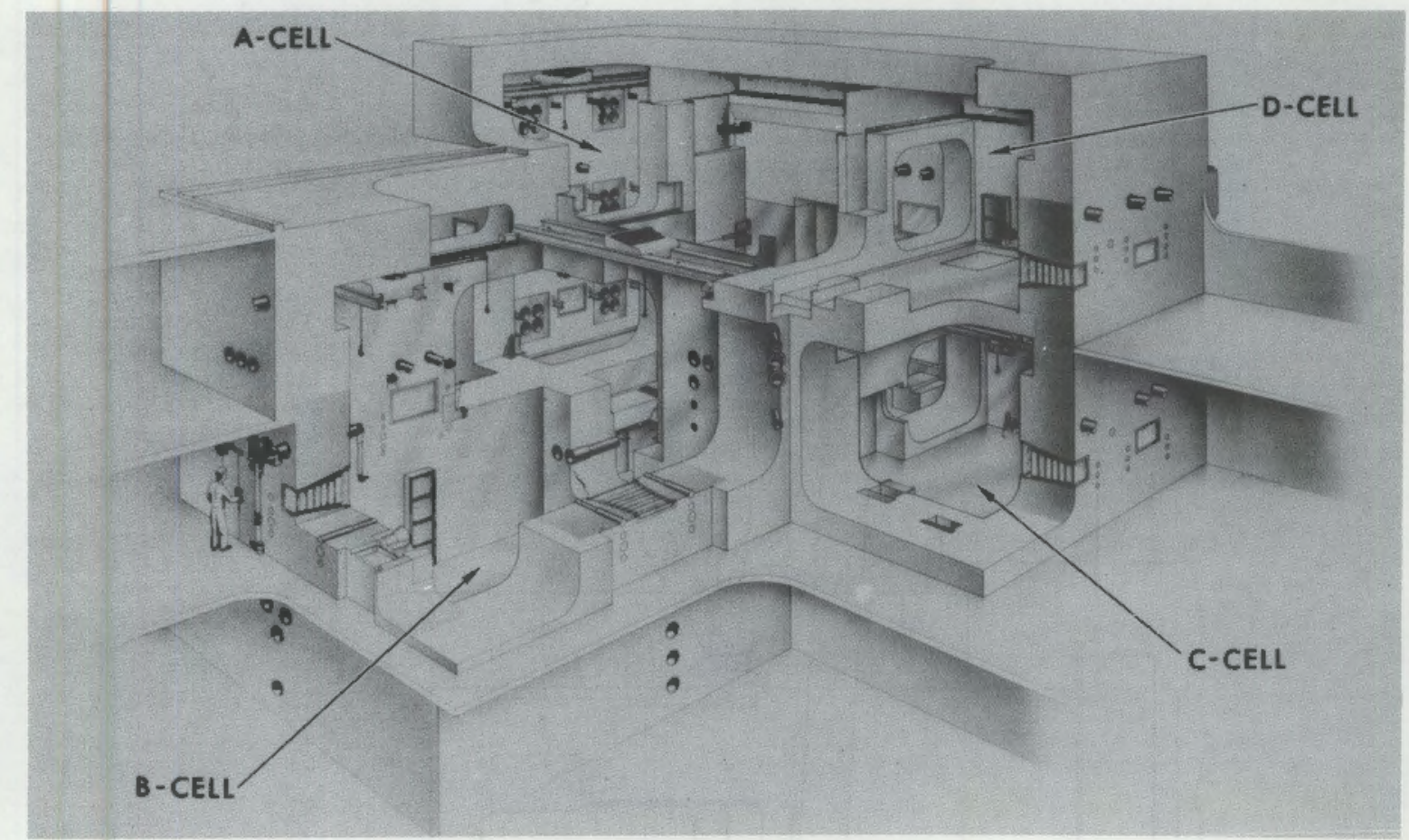

FIGURE 4.2. Isometric View of the Radiochemical Engineering Cells

- a 198-cm-wide, 45-7-cm-thick (maximum) hinged steel entry door that opens into the airlock cell for transfer of large materials. Because the airlock floor is at grade and the B-Cell floor is $3.05 \mathrm{~m}$ below grade, the cell entry has a 3.05-m-high "step".

- a 0.91-m-wide, 10.2-cm-thick hinged steel crane door that opens into the airlock cell to permit the two B-Cell cranes to travel into the airlock cell.

- a 30.5-cm-wide, 38.1-cm-high transfer mechanism opening that angles through the north cell wall into the cell for transfer of samples and other small materials between the cell and the service gallery.

- Three oil-filled, 1.2-m-thick lead-glass shielding windows located on the first floor level and centered along the three cell walls, which are adjacent to service and operating galleries. Two windows are located on the second floor level on the south and west sides of the cell. 


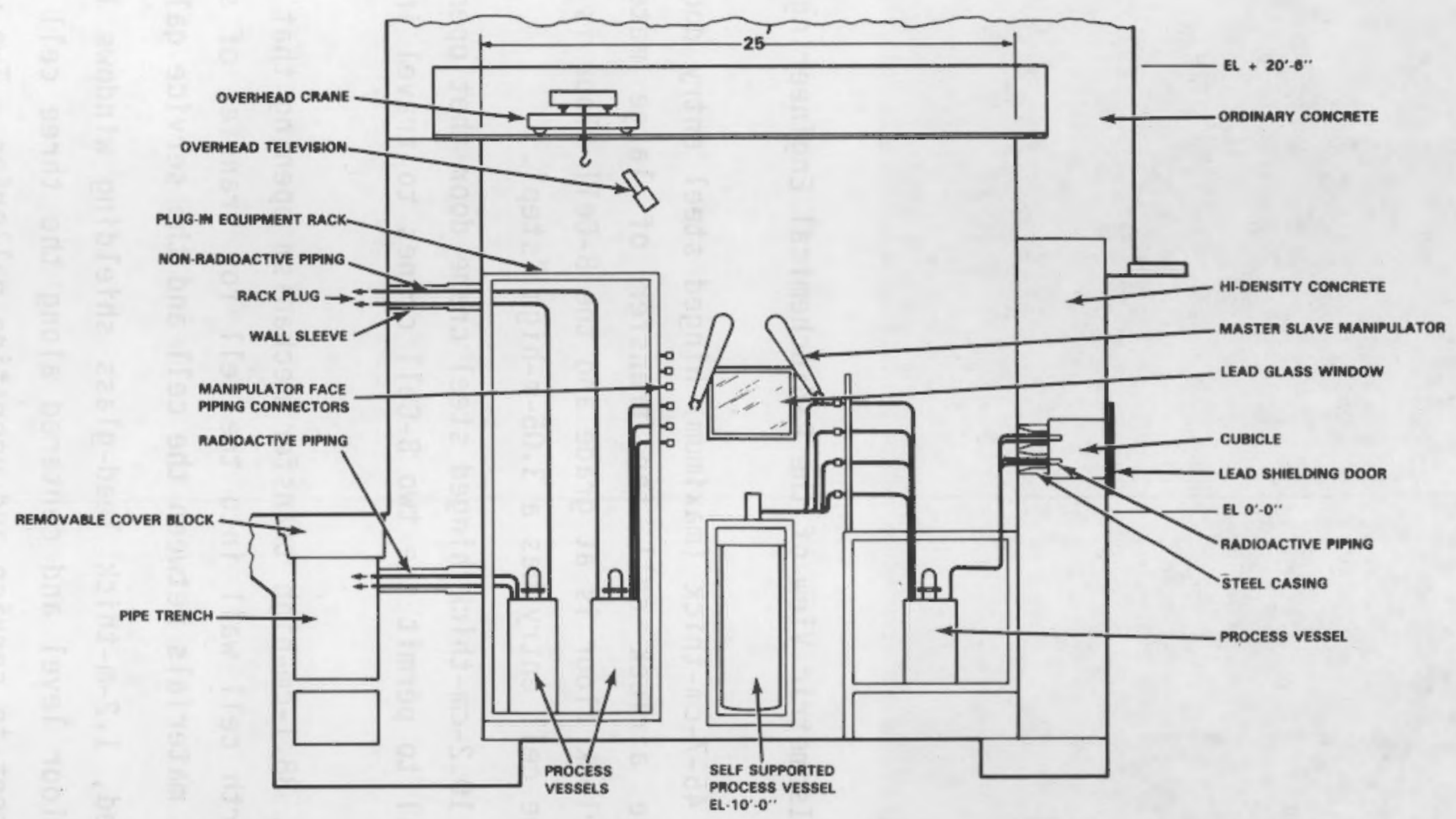

FIGURE 4.3. Elevation View of the B-Cell Equipment Arrangement 
- Standard straight $25.4-\mathrm{cm}-d i a$ paired sleeves located immediately above each window on the first floor level and also above each window at the second floor level above the crane rails. These sleeves are primarily used for insertion of master-slave manipulators, but may also be used for other services including viewing cameras.

- Numerous cell wall penetration sleeves that are $30.5 \mathrm{~cm}, 20.3 \mathrm{~cm}$, or $10.2-\mathrm{cm}$ in diameter and are stepped. These sleeves are used for piping and electrical services and rack plugs. The $20.3-\mathrm{cm}$ and 10.2-cm sleeves are grouped around the shielding windows; the $30.5-\mathrm{cm}$ sleeves are located away from the windows and at higher and lower elevations for inserting rack plugs or cameras.

- Two overhead cranes with capacity ratings of six tons and three tons operate on a conmon rail at an elevation of $5.33 \mathrm{~cm}$ above grade to move large equipment within B-Cell or into the airlock cell.

- A downdraft ventilation system with inlet ceiling ducts equipped with automatically controlled dampers, antibackflow dampers, and medium-efficiency filters. The $0.61 \mathrm{~m}$ by $2.54 \mathrm{~m}$ rectangular outlet opening is located on the north cell wall below the shielding window.

- Two cubicles located in the west cell wall at the first floor on either side of the shielding window. Cubicles are cavities formed by casting $45.7-\mathrm{cm}-$ thick steel blocks in the concrete wall with the face of each $348-\mathrm{cm}^{2}$ block flush with the inside wall of the cell. The cavity or cubicle thus created in the cell wall is sealed on the gallery side by an aluminum or clear plastic ventilation control door and shielded by a 10.2-cm-thick hinged steel door. In-the-wall piping routed from the service galleries and from other building areas into the cubicle provide for manual connections of radioactive and nonradioactive services inside the cubicle. Each cubicle 
casting has four $22.8-\mathrm{cm}$-dia openings into the cell. Thus, process equiprnent with mating plugs may be "plugged in" to the cubicle openings from inside the cell. These plugs may be connected and disconnected without entering the cell as described in Section 4.2.

- A 1.2-m-wide pipe trench located below the airlock cell floor and connected to B-Cell by 30.5-cm stepped sleeves. The pipe trench extends the full width of $\mathrm{B}-\mathrm{Cell}$ and is covered by high-density concrete shielding blocks that are $0.61-\mathrm{m}$ thick. The pipe trench provides for interconnection of radioactive process piping by semiremote manipulations from behind portable barriers.

\subsection{EQUIPMENT ARRANGEMENT}

The RLFCM and associated equipment are designed as a modular system. The equipment in these modules, or racks, and their locations in B-Cell is described below:

\subsubsection{Equipment Rack Concept}

Vessels with closely related functions and their associated piping are grouped together and mounted in structures called racks. Equipment racks simplify remote handling, benefit field installation by allowing prefabrication, facilitate replacement of groups of equipment, and permit efficient adaptation of complex piping systems to restricted cell geometry.

A typical rack (Figure 4.4) consists of the rack frame, service piping (which is integrally welded into the frame and arranged to fit sleeves in the cell walls), process vessels and equipment, piping systems, and various connectors that are generally on the rack face that is accessible to the cell manipulators. The rack shown is designated as Equipment Rack $2 \mathrm{~A}$ and is used for in-cell treatment of vitrification off gases. Other equipment racks with their respective functions and designations are listed in Table 4.1. The rack designations denote the location of the rack in the cell as described in Section 4.2 .2 . 


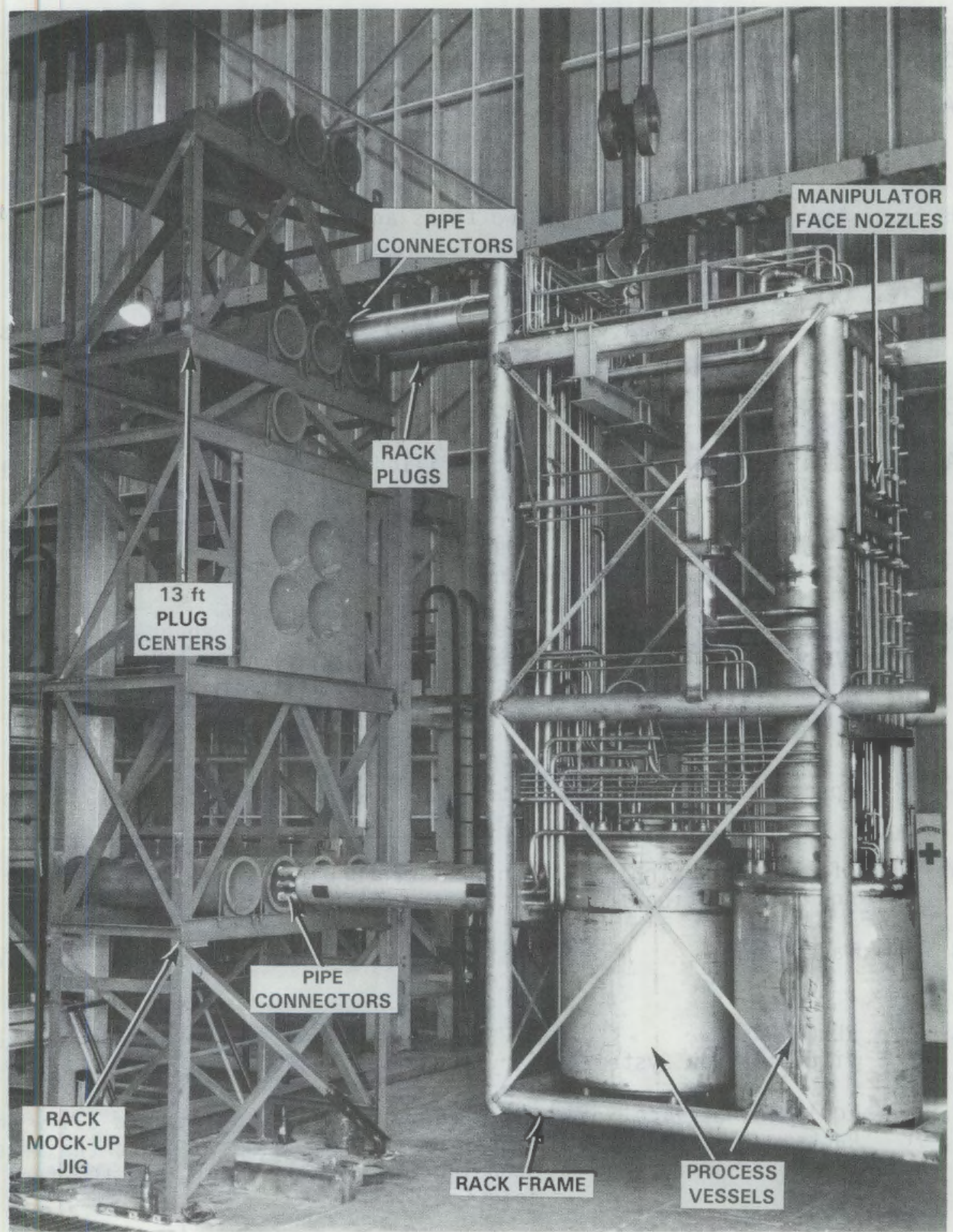

FIGURE 4.4. Equipment Rack 2A Photographed Before $\mathrm{Placement}$ in the Shielded Cell 


\section{TABLE 4.1. Equipment Racks and Function}

Rack

$1 \mathrm{~A}$ Concentration and acid recovery

1B Auxillary feed storage tanks

$2 A$

$3 C$

$4 \mathrm{~A}$

$7 A$

Spent Fuel Shearing and Dissolution

Spent Fuel Storage

3 A Off-Gas Scrubbing And Condensation

3B Waste Feed

6A RLFCM Waste Vitrification System

3C, Equipment Service 4C, 7C Racks

5A Tube Furnace
Major Equipment in Rack

Waste concentrator and condenser, acid fractionator and condenser, evaporator bottoms and condensate tanks.

Two tanks and reflux condenser.

Packed scrubber, off-gas preheaters, condensers, HEPA filtration, and condensate storage tank.

Packed scrubber and condenser.

Water-filled canister storage rack for 10 canisters: 6 positions for 8-in.-dia canisters, 4 positions for 12-in.-dia canisters, 2 positions hold the fuel dissolver system hull rinse tanks.

Fuel handling table and shear for PWR fuel elements, fuel dissolver, holding tanks and dissolver off-gas treatment, including condensers, demisters and silver zeolite beds for iodine sorption.

Water-cooled storage basin for up to nine PUR fuel bundles.

Venturi scrubber and scrub solution recirculation tank.

Waste preparation and waste feed tanks for LFCM.

RLFCM, canister handling turntable and necessary supporting dunnage.

Racks contain service piping and allow implementation of process services to the free standing racks ( $5 \mathrm{~A}$ and $6 \mathrm{~A}$ ), and the fuel dissolution system.

Induction-heated furnace (currently in standby) 
Rack frames are fabricated mainly from tubular stainless steel such as the 15.2-cm (6-in.) Sch. 80 pipe frame shown for the 2A Rack. These members were selected for maximum rigidity and minimum weight. The weight of an entire rack assembly is limited to six tons by the capacity of the in-cell crane. The racks were designed to hang from the cell wall and to be supported by the rack plugs or to rest on the cell floor. Racks taller than about $4.87 \mathrm{~m}$ are designed to be tipped $90^{\circ}$ during transfer into the cell because of the limited vertical clearance between the crane hook and the airlock cell floor at the cell entrance. Cross-bracing gives these racks the extra rigidity required for safe remote handling.

Rack plugs also connect process piping. Typically, piping for up to 35 nonradioactive services extends through each of two upper plugs, and piping for up to 10 radioactive process streams extends through each of two lower plugs. For racks mounted on the B-Cell/airlock wall, the upper plug piping terminates in the airlock cell and the lower plug piping terminates in the pipe trench. The pipe trench connection is accessible from the airlock cell. Piping in the plugs of the other racks terminates in the service galleries or in the shielded cubicles. This allows piping connections to be made to the various racks without entering the cell. Shielding is provided in all plugs except those that terminate in the pipe trench of the airlock cell (Racks 1A, 1B, and 2A). To provide a shielded plug, the piping is bent to provide a radiation barrier and the plug is filled with steel or lead shot.

The shape of the rack plugs are either stepped-cylindrical, straightcylindrical, or conical-cylindrical, depending on the shape or location of the mating sleeves in the cell walls. The upper plugs actually support the rack, thereby forming a cantilever structure.

Stainless steel or titanium piping extends to the various process vessels from the manipulator face of the rack. This rack face is located and arranged so that the piping connections and nozzles are accessible with master-slave manipulators. Connectors away from the manipulator face on the process vessels, agitators, pumps, tube bundles, and off-gas lines can be actuated using the overhead crane and an impact wrench. 


\subsubsection{Equipment Layout in B-Cell}

Arrangement of the equipment and its relationship to the various cell features and equipment system in B-Cell are shown in Figure 4.5. The functions of the major equipment racks are summarized in Table 4.1. Feed and process off-gas treatment racks are located in the corners of the cell where they have hot process service access to the high- or low-level storage vaults. The RLFCM and canister handling turntable, the $5 \mathrm{~A}$ induction heated tube furnace, and $a$ fuel shearing and dissolution system are located in front of the viewing windows to facilitate remote maintenance. Also, the service racks $3 \mathrm{C}, 4 \mathrm{C}$, and $7 \mathrm{C}$ are located adjacent to the window positions, which provide access of process services to adjacent equipment racks and other equipment systems.

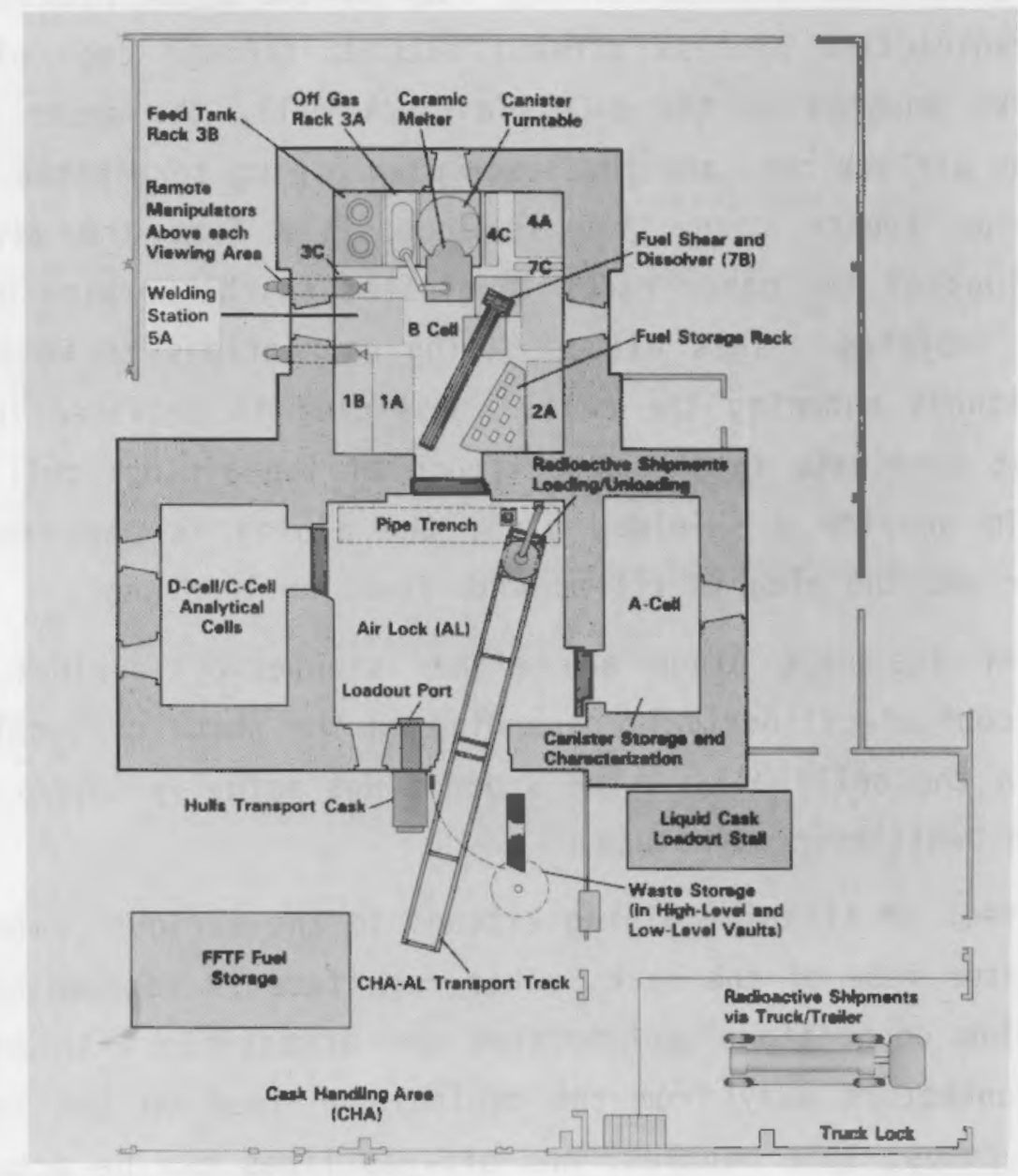

FIGURE 4.5. Plan View of the Radiochemical LFCM Pilot Plant Equipment in B-Cell 


\subsection{WASTE PREPARATION AND FEED SYSTEM}

The liquid waste preparation and feed system uses pulse-agitated tanks to assure waste solution homogeneity. The selection of pulse-agitated tanks as the RLFCM reference design was based on the varied nature of the solutions to be homogenized and on prior PNL experience with both the pulse-agitated and mechanically agitated feed tanks.

\subsubsection{Waste Preparation Tank Design and Operation}

The waste preparation system consists of two pulse-agitated feed tanks and related equipment (Figure 4.6 left). A pulse-agitated feed tank is comprised of three basic parts: the tank, a pulser tube, and air-displacement cylinders (Figure 4.6 right). Both tanks are an integral part of the new equipment rack.

Two conical-bottom, pulse-agitated feed tanks are used to prepare and contain the simulated high-level waste slurries for feeding to the RLFCM. Each tank, fabricated from $304 \mathrm{~L} S$, has a nominal diameter of $0.9 \mathrm{~m}(3 \mathrm{ft})$, and an overall height of $2.4 \mathrm{~m}(7 \mathrm{ft}, 9 \mathrm{in.)}$. The tanks each have cooling jackets positioned around their circumference, which provides $4.2 \mathrm{~m}^{2}\left(45 \mathrm{ft}^{2}\right)$ of heat transfer surface area. Each tank has an 0.5-m (18-in.-) dia penetration for inserting the pulser tube, and a $0.2-m(6-i n .-)$ dia penetration for inserting the supply leg of the feed tansfer system. The total capacity of each tank is $1250 \mathrm{~L}$, although the active volume of the tank is 1 imited to $1000 \mathrm{~L}$ to allow for adequate freeboard.

The pulse tube is fabricated from a 2.4-m (7-ft, 10-5/8 in.) section of 16-in. Sch. 40 pipe. A conical reducer welded to the botton of this tube has a 5-cm (2-in.) opening. A piston assembly that uses air to displace a fixed volume of fluid is mounted to the top of each pulser tube. The slave cylinder is driven by two double-acting air cylinders. The slave cylinder has a nominal cavity $0.3-m(12-i n$.$) dia \times 1.1-m(42-i n$.$) high with a displacement volume of$ $-60 \mathrm{~L}$.

The pulsing action forces the slurry in and out of the waste tank through the synchronous operation of the piston system. The pulse system operation can be divided into two basic steps: 1) the drive pistons, when forced from the bottom by injected air, raise the slave piston up, which draws slurry into the 

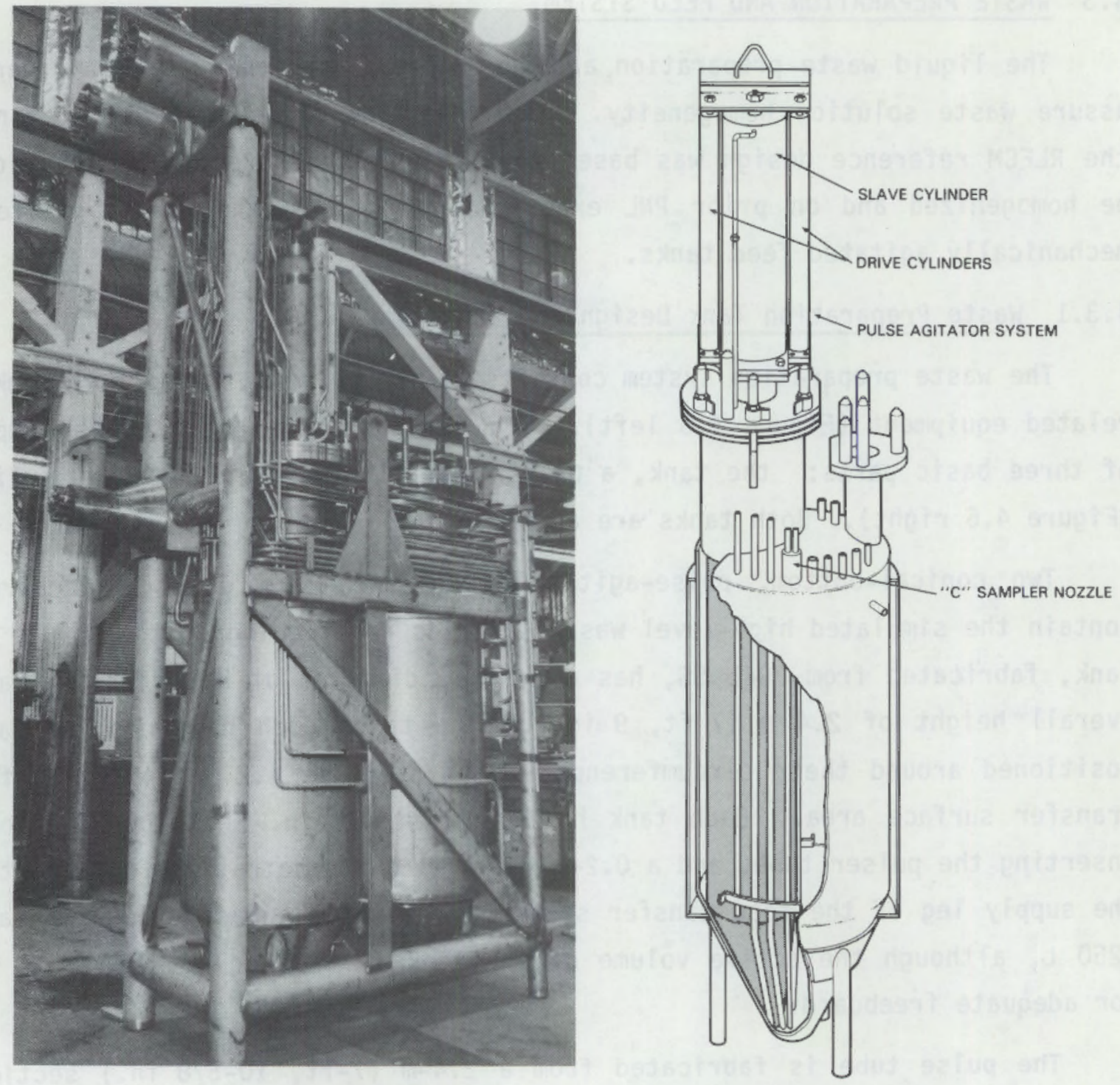

FIGURE 4.6. Waste Preparation System Rack and Detail of Pulse-Agitated Feed Tank

pulser tube, and 2) the drive pistons, when forced from the top by injected air, push the slave piston down, which forcess the slurry out of the pulser tube. The total volume of fluid displaced is $-60 \mathrm{~L}$, and the operating cycle is $180 \mathrm{sec}$. The action of the slurry displaced through the $5-\mathrm{cm}\left(2-\mathrm{in}_{0}\right)$ nozzle into the bottom of the pulser tube agitates the feed tank. The degree of agitation is adjusted by varying the pressure of the air to the drive pistons, and the cycle time for the slave piston. 
The pulse-agitated feed tank was chosen over a mechanical agitating system because PNL experience has shown that better homogenization is achieved with the pulsing action. Some of the features of the agitation system that are an improvement over the mechanically agitated systems are summarized below:

- The conical-bottom system of the feed tank produces greater fluid turbulence along the tank bottom than can be achieved with standard tanks and agitators. This leads to enhanced suspension of the solid particles of the feed slurry.

- The heat generation/removal problems inherent to mechanical agitation systems are essentially eliminated with the pulser tube. Only decay heat removal is required, and an external cooling jacket is adequate. No internal cooling coils are required.

- The degree of agitation of the feed slurry can be varied by adjusting the pulsing frequency and the intensity of the pulse.

- The pulse agitation system can be adjusted to homogenize high viscosity/high-solids slurries, and low viscosity/low-solids slurries.

- During the pulse agitation cycle, the entire volume of slurry in the tank is mixed. This produces a very homogeneous slurry from top to bottom, regardless of the actual volume of slurry in the tank.

\subsubsection{Waste Feeding Systems}

The waste feeding tank can accomnodate several types and configurations of waste slurry transfer devices. These include mechanically operated positivedisplacement pumps, air-driven pumps, and airlifts. The current feed system for the RLFCM is the air displacement pump.

The air displacement slurry (ADS) pump, is shown in Figure 4.7. The ADS pump, with driven check valves, has a pump chamber volume of $\sim 1 \mathrm{~L}$. This design allows for an average feed rate of up to $45 \mathrm{~L} / \mathrm{h}$. The pump is flanged, and the pump chamber is comprised of two concentric pieces of pipe. The outer pipe is a 33-cm-long section of $7.6 \mathrm{~cm}$ (3-in. Sch. 40) 304 stainless steel pipe, and 

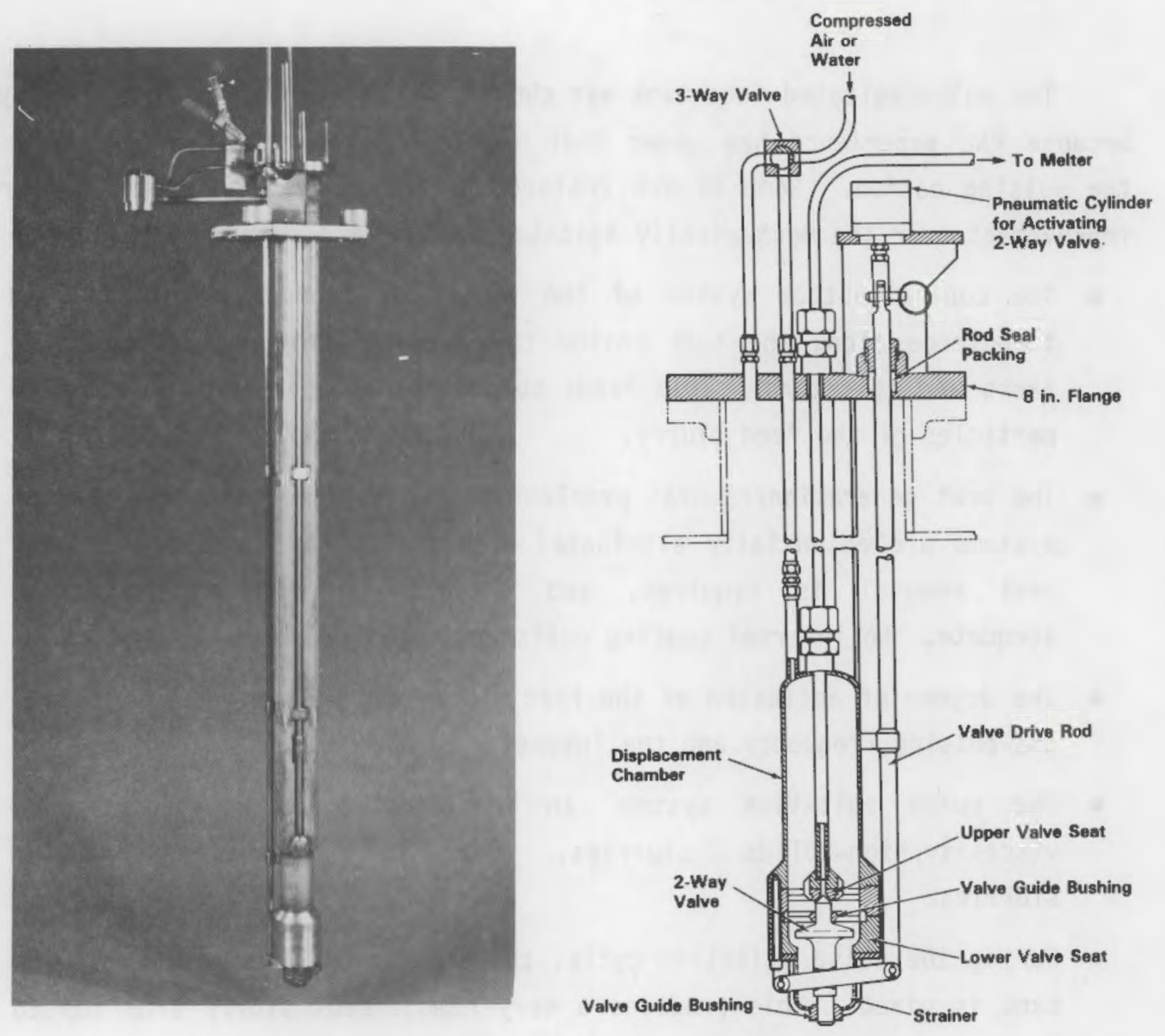

\section{FIGURE 4.7. Air-Displacement Pump}

the inner pipe is a $25.4 \mathrm{~cm}-1$ long piece of $3.8-\mathrm{cm}$ thick-walled tubing. A $6.35-\mathrm{cm}$-dia ball-type valve is used for the check valve. The seats are $0.32 \mathrm{~cm}$ by $45^{\circ}$ in the tubing and in the bottom flange.

Slurry flows in and out of the pump chamber through the $3.8-\mathrm{cm}\left(1-1 / 2-\mathrm{in}_{\text {. }}\right)$ orifice cut from the bottom flange. A double-acting pneumatic cylinder activates the check valve. Air and flush water enters the pump chamber through the top. The slurry is transferred to the RLFCM through $0.6 \mathrm{~cm}(3 / 8-i n$.$) SS$ tubing. 
The ADS pump operates through a series of four steps that are controlled by an electronic sequencer. During the first step of the cycle, the check valve is activated and opens the entrance orifice (port) and closes the chamber exit line. In the second step, a syringe, operated by a double-acting pneumatic cylinder, draws air from the chamber into the syringe. The resulting low cylinder pressure draws slurry from the feed tank into the pump. The check valve is then forced down, closing the entrance port and opening the exit port during the third step. In the fourth step, the pneumatic cylinder forces the syringe down, expelling pressurized air into the pump chamber thereby forcing slurry out of the chamber into the RLFCM. A sequencer repeats these process steps.

The ADS pump, with a 1-L capacity chamber, has achieved average slurry flow rates in the range of 35 to $45 \mathrm{~L} / \mathrm{h}$. The flow rate pulsates and spans a range from 0 to $110 \mathrm{~L} / \mathrm{h}$. There are two methods to adjust the flow rate with the ADS pump system. The first method involves varying the time for the discharge step of the cycle. A longer discharge cycle produces lower flow rates and, conversely, a shorter cycle leads to higher pump pressures and increased flow rates. A second method involves adjustment of the air pressure to the pneumatic cylinder that drives the slave piston. This changes the pressure developed in the pump chamber and directly affects the flow rate.

\subsection{RADIOACTIVE LIQUID-FED CERAMIC MELTER (RLFCM)}

\subsubsection{RLFCM Design Description}

\subsubsection{Function}

The function of the RLFCM is to vitrify an aqueous radioactive waste/ glass-former aqueous slurry and to discharge the resultant molten glass into a receiving canister. The RLFCM is also capable of accepting and vitrifying a dry solid feed.

\subsubsection{Type}

The RLFCM is a joule-heated ceramic-lined melting device. The nominal melt surface area is $0.5 \mathrm{~m}^{2}$. The melter is designed for a maximum slurry feed rate of $40 \mathrm{~L} / \mathrm{h}\left(80 \mathrm{~L} / \mathrm{h} / \mathrm{m}^{2}\right)$ and a normal operating feed rate of $25 \mathrm{~L} / \mathrm{h}$ 
$\left(50 \mathrm{~L} / \mathrm{h} / \mathrm{m}^{2}\right)$. The melter refractory arrangement is designed to contain glass at temperatures up to $1300^{\circ} \mathrm{C}$ and a viscosity of 100 poise. The melter is designed to operate in the pressure range of $+12.9 \mathrm{~cm}(+5 \mathrm{in.})$ of water to $-51 \mathrm{~cm}$ $(-20$ in.) of water relative to the cell. The normal operating pressure will be $25 \mathrm{~cm}$ ( $9.7 \mathrm{in.})$ of water below the cell atmosphere.

\subsubsection{Configuration}

The general configuration of the RLFCM is shown in Figure 3.6. The unit includes a ceramic-lined melter tank with air-cooled Inconel-690 plate electrodes, a monolithic ceramic submerged discharge throat block, a vertical airlift riser tube, an Inconel-690 discharge trough, an electrically heated discharge section, and a tapered discharge tube. The melter refractories are supported by an Inconel-lined containment vessel. The top of the containment vessel is flanged to accommodate the removable melting cavity lid and the discharge section lid. The containment vessel is positioned over and supported by the back edge of the canister handling turntable. A liquid metal seal below the melter outer discharge tube forms a gas-tight connection between the containment vessel and the turntable.

\subsubsection{Containment Vessel}

The containment vessel is a rectangular box $1.52 \mathrm{~m}(60-\mathrm{in}$.) wide by $2.16 \mathrm{~m}$ (85-in.) long by $1.19 \mathrm{~m}$ (47-in.) tall, of which the end $0.66 \mathrm{~m}$ (26 in.) was cut away to form a semicircular curved section. This curved section is 0.91-m (36-in.) wide and is intended to reduce the overall melter weight. The structural members, except for the upper flange, are made from stainless steel. The floor of the containment vessel, the tapered outer discharge tube, the discharge tube guide skirt, and the liquid metal seal diaphragm below the discharge tube are fabricated from $0.48 \mathrm{~cm}$ (3/16-in.) Inconel-690. These components are exposed to the highest operating temperatures and potentially to the corrosive molten glass, which requires the corrosion resistance afforded by the Inconel -690 alloy. 
The containment vessel walls are exposed to a much less hostile environment and are fabricated from $0.64-\mathrm{cm}$ (1/4-in.) Inconel-601 plate. The walls and floors are seal-welded at the edges to provide a gas-tight containment vessel.

The flange at the top of the containment vessel is $2.5-\mathrm{cm}$ (1-in.) Inconel-690 plate, which was used to minimize bowing and subsequent air inleakage when the lid section is bolted to this containment vessel flange.

\subsubsection{Melter Tank}

The melter tank is rectangular in shape, $0.61 \mathrm{~m}$ wide (24-in.) and 0.99-m long (39-in.). The tank is positioned in the square end of the containment vessel with its long axis perpendicular to the long axis of the containment vessel. The effective length of the tank is $84 \mathrm{~cm}$ (33 in.) due to the $7.6-\mathrm{cm}-$ (3-in.-) thick electrodes positioned at the end. The exposed glass surface area is $0.51 \mathrm{~m}^{2}\left(5.5 \mathrm{ft}^{2}\right)$. The highest point in the discharge throat weir, which establishes the maximum static glass level, is $0.36 \mathrm{~m}$ (14 in.) above the floor of the melter. The maximum static glass volume in the melter tank is $180 \mathrm{~L}\left(6.30 \mathrm{ft}^{3}\right)$.

As is discussed in Section 4.4.2, the melter tank refractory design utilizes multiple ceramic layers to resist the corrosive action of the anticipated glass formulations, to realize practical containment vessel surface temperatures, and to stay within the 9-ton weight limit imposed by the in-cell crane system. Figure 4.8 shows the refractory structure within the containment vessel and the multiple refractory design. Although water cooling has been used successfully on nonradioactive melting units, it is not practical in this radioactive cell because the cooling water would have to be routed to a holding tank system. Contamination from any source would force the closure of the melter cooling circuits because of the limited holdup volume of the holding tank system. Forced-air cooling was considered, but the weight of the required cooling jacket structure was not effective in refractory weight reduction. Also, forced-air cooling would put an additional load on the compressed air supply, and could compromise the operation of the melter in the event of any compressed air system failure. As a result, passive external cooling of the containment vessel was chosen as the most practical alternative. 


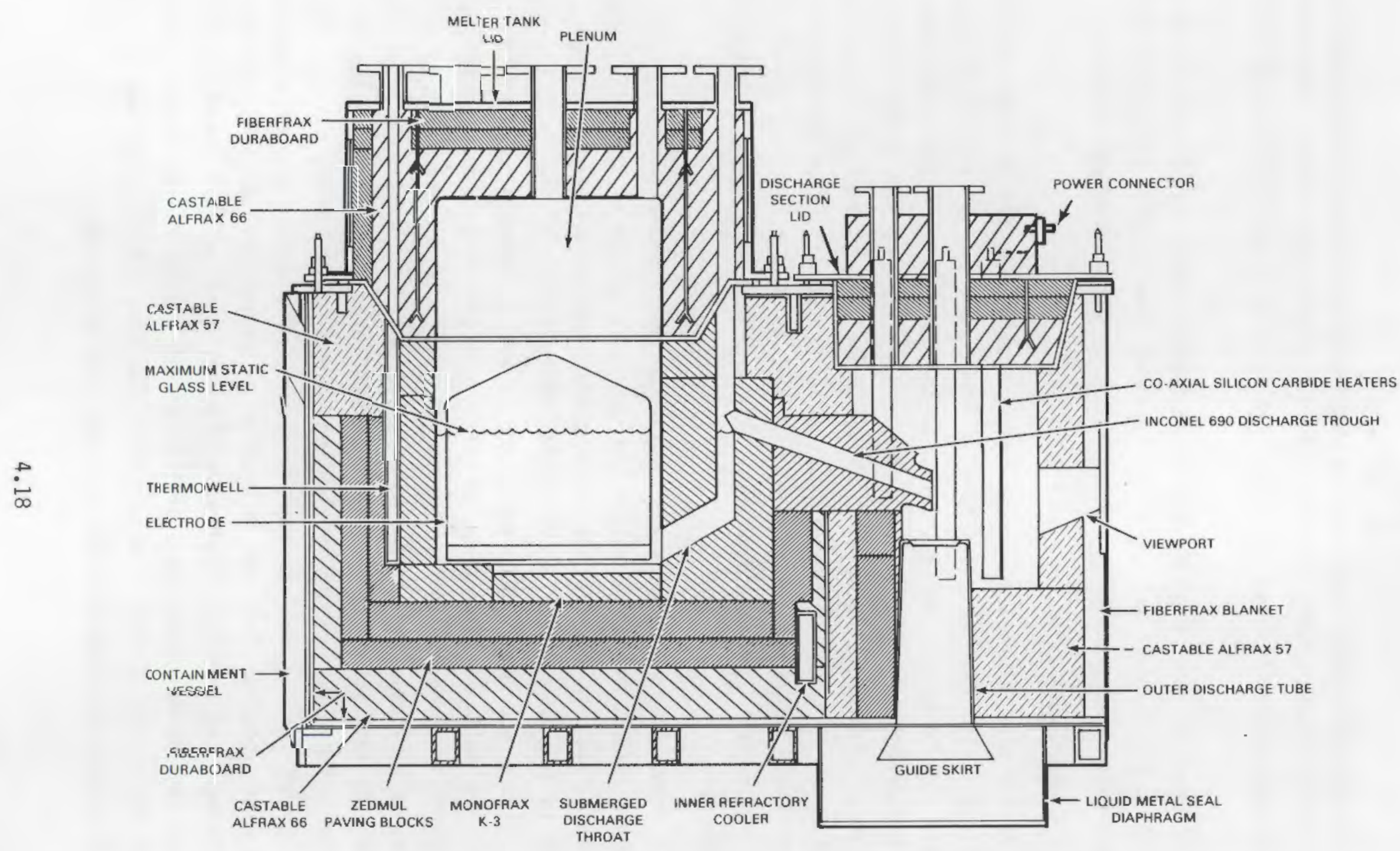

FIGURE 4.8. Lenythwise vertical Section of the RLFCM 
Six refractory types were used in the melter design: a fused-cast, chromia/alumina "Monofrax $\mathrm{K}-3^{\mathrm{I}}(\mathrm{a})$ and a fused-cast high chromia "Monofrax $E, "(a)$ a machine pressed and sintered AZS "Zedmu1-20",(b) a high alumina castable "Alfrax 66"(a) and a fused alumina bubble castable "Alfrax 57,"(a) and a high-density Alumina-Silica "Fiberfrax Duraboard."(a) The chemical composition and thermal properties of these refractories are further discussed in Section 4.4.2.

The glass-contact refractories (floor, side walls, discharge throat, and riser block) are made from fused-cast Monofrax K-3. The RLFCM melting tank was designed around two standard $k-3$ shapes. The throat block is fabricated from a standard 0.46-m- (18-in.-) wide, 0.30-m- (12-in.-) thick and 0.61-m (24-in.-) tall brick. The melter tank floor and side walls are fabricated from standard 0.46-m- (18-in.-) long, 15-cm- (6-in.-) wide, and 10-cm- (4-in.-) thick blocks. The end walls of the melter are fabricated from standard $0.30-m-(12-i n .-)$ wide, 0.61-m- (24-in.-) tal1, and 8-cm- (3-in.-) thick Monofrax E refractory.

Thermal analysis of the melter floor (see Section 4.4.2.2) predicted that in the melter floor, temperatures could be up to $1060^{\circ} \mathrm{C}$ at the interface between the $\mathrm{K}-3$ and Zedmul refractories, about $715^{\circ} \mathrm{C}$ between the Zedmul and the Alfrax 66 castable, and about $450^{\circ} \mathrm{C}$ between the Alfrax 66 and the Fiberfrax Duraboard material. With this temperature distribution, it is anticipated that, at least for the first few months of operation, the $K-3$ tiles in the floor would be surrounded with a low-viscosity glass. Also, it is anticipated that some glass will probably penetrate some distance into, or possibly completely through, the tile joints in the Zedmul layers and contact the Alfrax 66 layer. This initial penetrating glass is expected to have a high viscosity due to the relatively low temperatures in this region and due to the small amount of refractory dissolution that occurs. The initial glass penetration is expected to seal any potential glass migration paths. After a few months of operation, it is anticipated that a sludge layer will begin to form that will seal the K-3 floor joints to the downward movement of fresh glass.

(a) Product of the Carborundum Company.

(b) Product of the Zedmark Company. 
To minimize the initial glass migration through the floor refractories, the surface of the $\mathrm{K}-3$ tiles were ground to a finish specified in ANSI-63 (ANSI 1963). All sides were ground parallel and square to one another to $1 / 32 \mathrm{in}$. or better. This finish was limited to the high spots on the block surfaces. The few, normal pits present on the block surfaces were ground away. When the K-3 blocks were installed, each joining surface was covered with a thin layer of cement (produced by the Carborundum $\mathrm{Co}_{.}$) to fill these pits and to make up any differences allowed by the dimensional tolerances. To the extent possible, the $\mathrm{K}-3$ blocks were installed with a minimum of cement.

The largest standard machine pressed tiles of Zedmul were used $(30.4 \mathrm{~cm} \times$ $45.7 \mathrm{~cm}$ ) to reduce the number of tile-to-tile joints and to minimize the glass migration through the Zedmul refractory. Two courses of Zedmul tiles were used, with the maximum staggering of the joint pattern between the two courses to create the longest possible migration path for any glass through these layers. With the machine-pressed Zedmul tiles, the dimensional and squareness tolerances were tight and consistent between tiles. However, where the edges and corners were chipped away, and as with the K-3 tiles, the Zedmul tiles were installed with a minimum of tile-to-tile cement.

The final barrier to glass migration through the melter floor is the monolithic, cast-in-place Alfrax 66 layer. Penetration of this material by the molten glass at the anticipated temperatures in past installations, even along shrinkage cracks, has been very minor.

To assure that the dimensional and surface tolerances of the $\mathrm{K}-3$ and Zedmul tiles are utilized to their limit, the foundation on which these courses were positioned was made appropriately flat and true. Thus, considerable attention was given to realize a flatness of $\pm 1 / 32 \mathrm{in}$. of the top surface of the Alfrax-66 floor foundation casting.

A similar close tolerance approach was followed to minimize the glass leakage through the walls of the melting tank. For the back wall (opposite the discharge throat), surface ground $\mathrm{k}-3$ tiles, $10-\mathrm{cm}-\left(4-\mathrm{in}_{0}-\right)$ thick, $15-\mathrm{cm}-$ (6-in.-) wide, and 46-cm- (18-in.-) tall, was positioned vertically on the K-3 floor. The maximum static depth of the glass in the tank is $36 \mathrm{~cm}-(14 \mathrm{in.})$ and, with the $k-3$ tile positioned vertically, there are no horizontal 
refractory joints below the glass level that would be potential sites for upward drilling erosion of the $\mathrm{k}-3$. The horizontal joint at the bottom of the tank wall is expected to be protected with a sludge deposit after a few months of melter operation. The $\mathrm{K}-3$ tiles were installed with the casting scars on the bottom so that the higher grade $K-3$ material would be at and above the metal line (glass level) where refractory corrosion is expected to be the most severe. The surface finishing of the $k-3$ tiles, the minimal use of the intertile cement, and the flatness of the melter floor minimize washing (and subsequent widening) of the wall tile joints due to the glass convection in the meiter tank. The vertical $\mathrm{K}-3$ in the wall is capped with a horizontal $k-3$ course, which is $10 \mathrm{~cm}$ ( $4 \mathrm{in.}$ ) above the maximum static glass level. This joint should not be subjected to upward drilling problems.

The melter tank wall on the discharge throat side is fabricated with exactly the same techniques as was described for the opposite or back wall, except that the $\mathrm{K}-3$ throat block makes up about half of the entire wall.

The melter tank side walls each utilize two vertically positioned Monofrax $E$ tiles. With the superior corrosion resistance of the Monofrax $E$ and the fact that the wall will normally be cooled by the cooling air passages in the electrodes, little corrosion or glass penetration is anticipated through these tile pieces. The single layer of Zedmul behind the Monofrax $E$ is expected to minimize what little glass leaks through the Monofrax E, and whatever does get through the Zedmul will be stopped by the monolithic Alfrax 66 casting behind the Zedmul.

To prevent the Alfrax 66 monoliths from cracking due to thermal expansion, considerable care was taken to prevent the three vertical castings from bonding to one another or to the floor casting. In this manner, it is expected that as dimensional changes occur with the temperature transients, the monolithic castings can freely move relative to one another. This motion will tend to lessen the potential for cracking at the center of the castings where the temperature and glass migration probability is the highest.

Since little, if any, glass penetration into the melter tank walls is anticipated above the maximum static glass level, there is no need for the corrosion resistance of Zedmul or Alfrax 66. Therefore, these materials are 
replaced with the more insulating refractory, castable Alfrax B1-57. The Alfrax B1-57 yields a lower containment vessel surface temperature for the upper portion of the melter and results in weight reduction of the final melter weight.

Past experience has shown that certain melter operating conditions will cause some of the metal oxides in the glass to be reduced to elemental metals. These metal alloys precipitate on the melter floor and agglomerate into nodules. The possibility exists, under these conditions, for the creation of a low resistance electrical path across the melter floor between the two electrodes. This would disrupt the normal electrical current flow through the glass. To counter this situation, three floor tiles positioned in the center of the meiter tank were machined to form a tapered trough. The axis of the trough lies parallel to the two electrodes. The trough is $2.5-\mathrm{cm}$ (1-in.) deep at the center, and slopes away from the two electrodes. It is anticipated that the bulk of the metals will tend to collect in the bottorn of the floor trough. This will not only minimize the possibility of the formation of a lowresistance electrical path between the two electrodes, but it will enhance the possibility of removing the accumulated metal by an evacuated-canister technique.

The melter tank lid is shown in place over the melter in Figure 4.8 . Figure 4.9 is a plan view showing the nozzle arrangement that penetrates the lid refractories.

The melter cavity extends upward into the lid to realize a $63.5-\mathrm{cm}$ (25-in.) freeboard (plenum) over the maximum static glass level. This freeboard was specified to minimize the entrainment of particulate into the melter off-gas line. This plenum is lined with a monolithic casting of Alfrax 66, which is backed up on all sides and the top with $10.2 \mathrm{~cm}$ (4 in.) of Fiberfrax Duraboard. The nozzle flanges are stainless steel, but the nozzles themselves are Incone1-690.

Where glass contact is made through a nozzle (thermowell, pneumatic dip tubes, etc.), the nozzle material ends at the lid surface and an A1frax B1-57 sleeve is cast through the Duraboard and the nozzle to provide electrical isolation between the glass probe and the nozzle. 


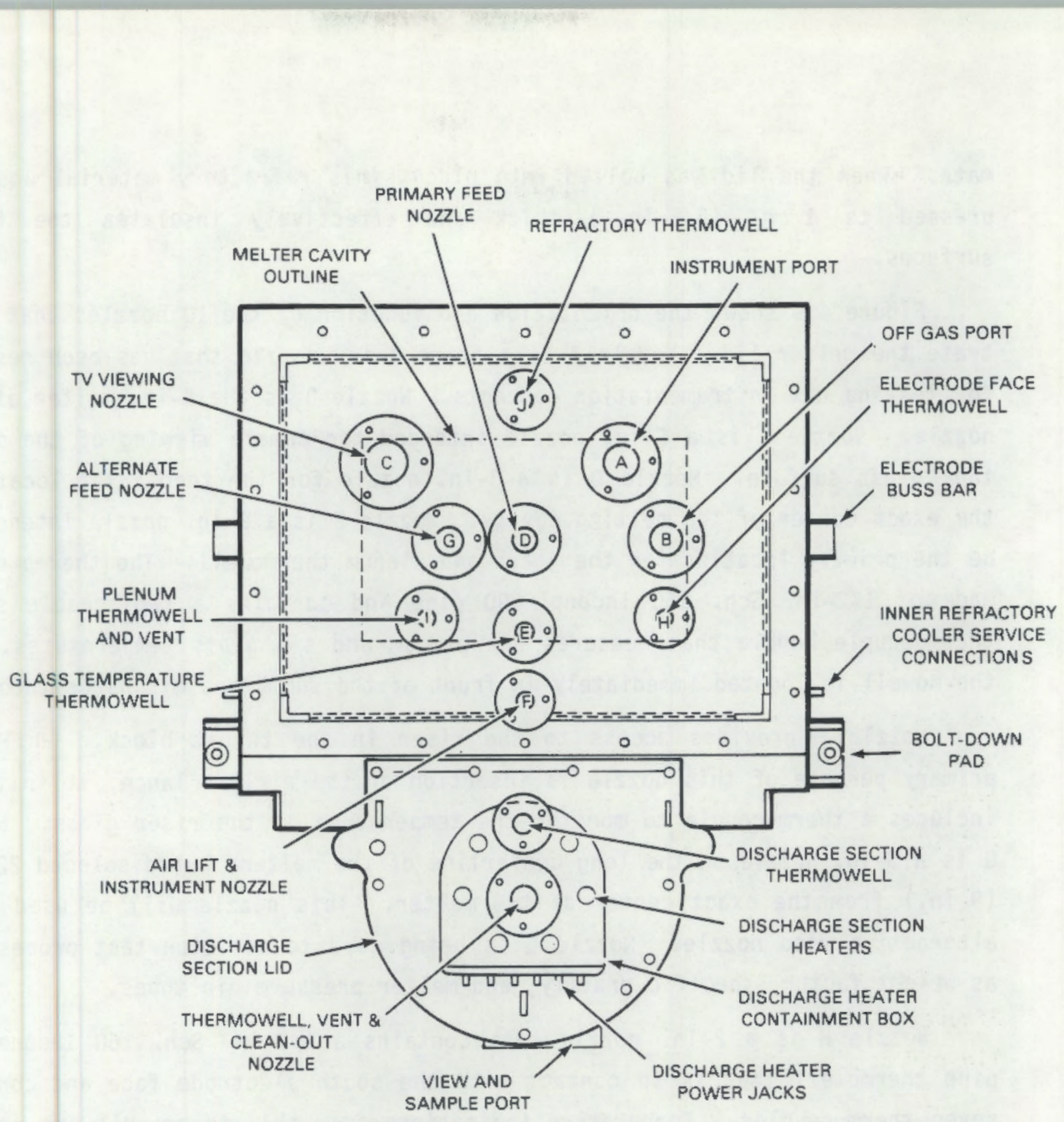

FIGURE 4.9. LFCM Lid Nozzle Arrangement

The melter lid is bolted to the containment vessel flange and the flanged joint is gasketed with two side-by-side pieces of $2.5 \mathrm{~cm}\left(1-\mathrm{in}_{\text {.) }}\right.$ square braided Fiberfrax rope. After the $f l a n g e$ nuts are tightened, the gasket rope is compressed to about $1-\mathrm{cm}\left(3 / 8-i_{\text {. }}\right)$ thick and about $6-\mathrm{cm}\left(2-1 / 2-\mathrm{in}_{\text {. }}\right)$ wide. This joint has minimal air inleakage with the normal $10 \mathrm{in.} \mathrm{of} \mathrm{water} \mathrm{vacuum} \mathrm{differ-}$ ential across the gasket. A 5-cm- (2-in.-) thick Fiberfrax blanket is positioned on the melter tank where the melter and the lid refractory surfaces 
mate. When the lid was bolted into place, this refractory material was compressed to $1 \mathrm{~cm}-\left(3 / 8-i_{-}-\right)$thick and effectively insulates the flange surfaces.

Figure 4.9 shows the orientation and function of the 10 nozzles that penetrate the melter 1id. Nozzle $A$ is a spare 4-in. nozzle that has been reserved for testing new instrumentation concepts. Nozzle B is the 4-in. melter off-gas nozzle. Nozzle C is a 5-in. nozzle intended for camera viewing of the melter tank glass surface. Nozzle $D$ is a $3-i n$. nozzle for the feed inlet located at the exact center of the melting cavity. Nozzle $E$ is a 2-in. nozzle intended to be the primary location for the glass and plenum thermowell. The thermowell is made of 1/2-in. Sch. 160 Inconel-690 pipe and contains a replaceable seventhermocouple bundle that measures one plenum and six glass temperatures. The thermowell is located immediately in front of the submerged discharge throat.

Nozzle $F$ provides access to the riser in the throat block. While the primary purpose of this nozzle is insertion of the airlift lance, it initially includes a thermocouple to monitor the temperature of the riser glass. Nozzle $G$ is a 3 -in. nozzle on the long centerline of the melter, but displaced $22.9 \mathrm{~cm}$ ( 9 in.) from the exact center of the melter. This nozzle will be used as an alternative feed nozzle. Nozzle $G$ is being used to position test probes such as weight factor, specific gravity, and melter pressure dip tubes.

Nozzle $H$ is a 2-in. nozzle that contains a 1/2-in. Sch. 160 Incone1-690 pipe thermowell that is in contact with the south electrode face and contains seven thermocouples. Temperature indications from this thermowell are used to correlate the electrode air cooling exhaust temperature with the implied electrode temperature. Following this calibration, this nozzle will be available for other as-yet-unidentified melter sensors.

Nozzle I is a 2-in. nozzle with a two-fold use. It contains another seven thermocouple Inconel 690 thernowe11. This series of thermocouples will monitor a $12-i n$. band straddling the maximum static glass level. Information from these thermocouples will be used to study temperature variations in the glass and cold cap for indications of off-normal melter conditions. In addition to the thermowell, a 2-in. pressure equalizing line will be attached to this nozzle connecting the melting tank and the discharge section plenums. 
Nozzle $J$ is a 2 -in. nozzle that accommodates another replaceable 1/2-in. Sch. 160 Inconel-690, seven thermocouple thermowell. This thermowell is inserted at the $k-3 /$ Zedmul interface in the back wall. Seven thermocouples, spaced $3 \mathrm{in}$. apart, monitor the $\mathrm{K}-3$ cold face temperature from the floor of the melter to the top of the vertical k-3 liner blocks. Information from these thermocouples, compared with glass temperature indications, will be used to estimate the corrosion occurring by the K-3 tank liner.

The thermowells positioned in nozzles $E, H, I$, and $J$, and the airlift lance in nozzle $F$, are all electrically insulated from the melter lid nozzles and all of the sheaths or lines that emerge from these flanged devices are electrically isolated from all metallic surfaces in the cell. The thermocouples are insulated from the thermocouple sheath; however, it is anticipated that this insulation will break down with time. Under these circumstances, the thermocouple signal wire will assume the same potential with respect to ground as the glass surrounding the thermowel1. Signal conditioners on the thermocouple output signal will be used to remove any ac coinponent that may be on the incoming themocouple signals.

\subsubsection{Electrodes}

The electrodes are 7.6-cm- (3-in.-) thick slabs of Inconel-690, 56-cm (22-in.) wide, and 53-cm (21-in.) tall. The electrode feet are 5-cm (2-in.) thick, $10-\mathrm{cm}$ (4-in.) wide, and 56-cm (22-in.) long, and are welded along the bottom front edge, giving the electrodes an "L"-shaped appearance. The electrodes are designed to clear the side walls by $2.5 \mathrm{~cm}(1 \mathrm{in}$.) to preclude erosion of the melter tank lining refractories due to excessive current flux near the walls. The front edges of the electrodes are rounded to a $2.5-\mathrm{cm}$ (1-in.) radius, and the electrode feet taper inward at $10^{\circ}$. A melter electrode is depicted in Figure 4.10 .

The electrode bus bars are $10 \mathrm{~cm}$ ( 4 in.) in diameter and penetrate horizontally through the melter cavity refractory walls and the melter containment vessel. Each electrode bus bar was fitted into a hole drilled through the electrode and solidly welded on both sides. This assures a low resistance current path from the bus bar to the electrode. The centerline of the bus bar is $45.7 \mathrm{~cm}$ (18 in.) above the bottom of the electrode and $47.0 \mathrm{~cm}(18.5 \mathrm{in}$.$) .$ 


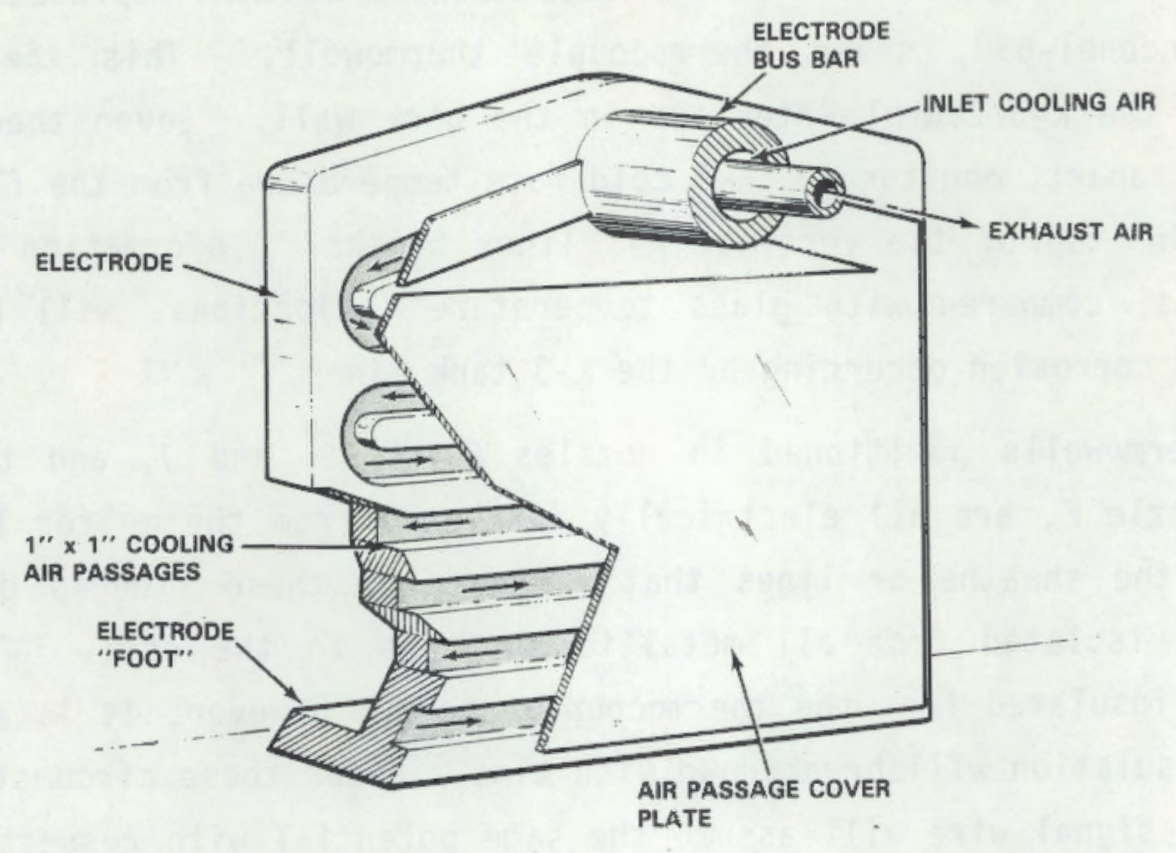

FIGURE 4.10. Melter Electrode

above the melter floor. This $1.3-\mathrm{cm}(0.5-\mathrm{in}$.$) spacing provides adequate clear-$ ance between the melter floor and the electrode to allow for thermal expansion. Only a minimum clearance was allowed around the electrode bus bar to maximize the load-carrying characteristics of the refractories. The refractories support the weight of the electrode bus bar, electrode connector and power cables. A clearance of $1.3 \mathrm{~cm}(0.5 \mathrm{in.})$ is provided between the electrode bus bar and the containment vessel to minimize the electrical arcing potential. A mechanical stuffing-box gland-seal, using a single ring of 6.5- $\mathrm{cm}^{2}\left(1-i \mathrm{n}^{2}\right)$ braided Fiberfrax rope around the electrode bus bar provides not only additional electrical isolation, but also eliminates air inleakage under normal melter operating conditions.

The electrodes are cooled using compressed air flowing through a serpentine passage. The cross-sectional area of the passage is $6.5-\mathrm{cm}^{2}\left(1-\mathrm{in} .^{2}\right)$, and is $~ 3.63-\mathrm{m}$ (143-in.) long. The electrode bus bar is nollow, $10.2 \mathrm{~cm}(4-i n$.$) OD$ and 5.72-cm (2.25-in.) ID, and contains a coaxial inner pipe, $4.45-\mathrm{cm}$ (1.75-in.) 00 and 2.84-cm (1.12-in.) ID. Compressed air at 15 psig (maximum) flows through the annulus between the two coaxial pipes toward the electrode. 
Within the electrode slab a port connects the top end of the cooling passage to the annulus. Cooling air flows down through three serpentine loops, across the bottom of the electrode, up the side, and back to the electrode bus bar. Another port within the electrode slab connects the hot exit air to the inner coaxial pipe. The hot cooling air is exhausted directly into the cell atmosphere. A flexible metal diaphragm at the outboard end of the bus bar seals the annulus between the two coaxial pipes, preventing the loss of the cooling air. The diaphragm also allows some movement of the inner pipe with respect to the bus bar as a result of temperature differences between the two pipes.

The cooling air passages are formed by milling a continuous $1-i n .^{2}$ slot in the serpentine pattern described above on the back side of the $6.4-\mathrm{cm}$ (2-1/2-in.-) thick Inconel-690 electrode s1ab. Adjacent passageways are spaced $1 \mathrm{in}$. apart. The return bends at the ends of the serpentine loops are semicircular. After the milling operation was complete, the passages were covered by welding a 1.3-cm (1/2-in.) Inconel-690 plate to the back side of the electrode slab. The plate was welded around the outside and between adjacent passageways.

By milling the 1-in.-deep slots in the electrodes, the effective electrode thickness on the front of the electrode was reduced to $3.8 \mathrm{~cm}$ (1-1/2 in.). This electrode thickness is adequate for the projected life of the melter. Experience indicates that the corrosion severity on the back side of the electrode is much less than that observed on the front side of the electrode; thus, the 1.3-cm (1/2-in.) plate covering the cooling air passages on the back side of the electrodes is adequate for the projected life of the melter.

The cooling air pattern was arranged to flow from the top of the electrodes to the bottom to achieve the greatest cooling at the top of the electrodes where the glass temperatures are generally the highest, and the least cooling at the bottom where temperatures are usually lower than desired. The electrodes were installed in the melter with the hot exhaust air passage from the bottom of the electrode on the discharge throat side of the melter.

A thermocouple inserted in the exhaust air stream was correlated with the electrode face thermocouples. The exhaust air temperature is used to estimate the approximate temperature of the electrode slab. There are no temperature 
indicating sensors monitoring the electrode temperature directly. Cooling air flow rate and temperature rise measurements permit the calculation of the heat removed from the electrodes. Cooling air flow rate is manually controlled by adjusting an air flow control valve.

\subsubsection{Electrode Power Connector}

The electrical power to the melter, nominally 1000 amps at 90 volts and $60 \mathrm{~Hz}$, is conducted to the melter through six $4 / 0$ extra flexible wire cables, three to each electrode. The cable-to-electrode connecting device is shown in Figure 4.11. The connector is replaceable. The Inconel-690 connector is 6.4-cm (2.5-in.) thick, 11.4-cm (4.5-in.) wide, and 39.4-cm (15.5-in.) long. A 10.2-cm- (4-in.-) dia hole in the upper portion of the connector matches the OD of the outer end of the electrode bus bar. The connector has been split through the centerline of the bus bar hole and the saw cut has been surfaced to provide a 3-mm (1/8-in.) clearance between the two pieces when reassembled, maintaining the original 4-in. ID. Two captive machine screws enable the bus bar hole to be opened, positioned on the end of the electrode bus bar, and clamped tightly into place.

Two hundred square centimeters (30 in. ${ }^{2}$ ) of direct contact surface are available between the connector and the bus bar. The minimum cross section area of the connector is $73 \mathrm{~cm}^{2}\left(11 \mathrm{in.}{ }^{2}\right)$. Based on this value, the resistance of the Inconel connector from the copper terminals to the bus bar surface should be no greater than $4 \times 10^{-7}$ ohms. At 1000 amps, the power dissipated in the connector body should be no greater than 40 watts.

Three vertical cooling fins 3-mm- (1/8-in.-) thick, 2.5-cm- (1-in.-) tall, and 16.3-cm- (6.4-in.-) long have been added to the front surface of the connector to minimize the heat flow from the copper to Inconel terminal connection.

Three cylindrical sockets, 1.90-cm (0.75-in.) and 4.45-cm (1.76-in.) deep, have been bored into the bottom of the connector, parallel to its centerline, to receive the insulation-stripped ends of the three power cables. A machine screw entering each power cable socket perpendicular to the centerline of the power cable presses an Inconel-690 wedge-shaped shoe onto the side of the power 

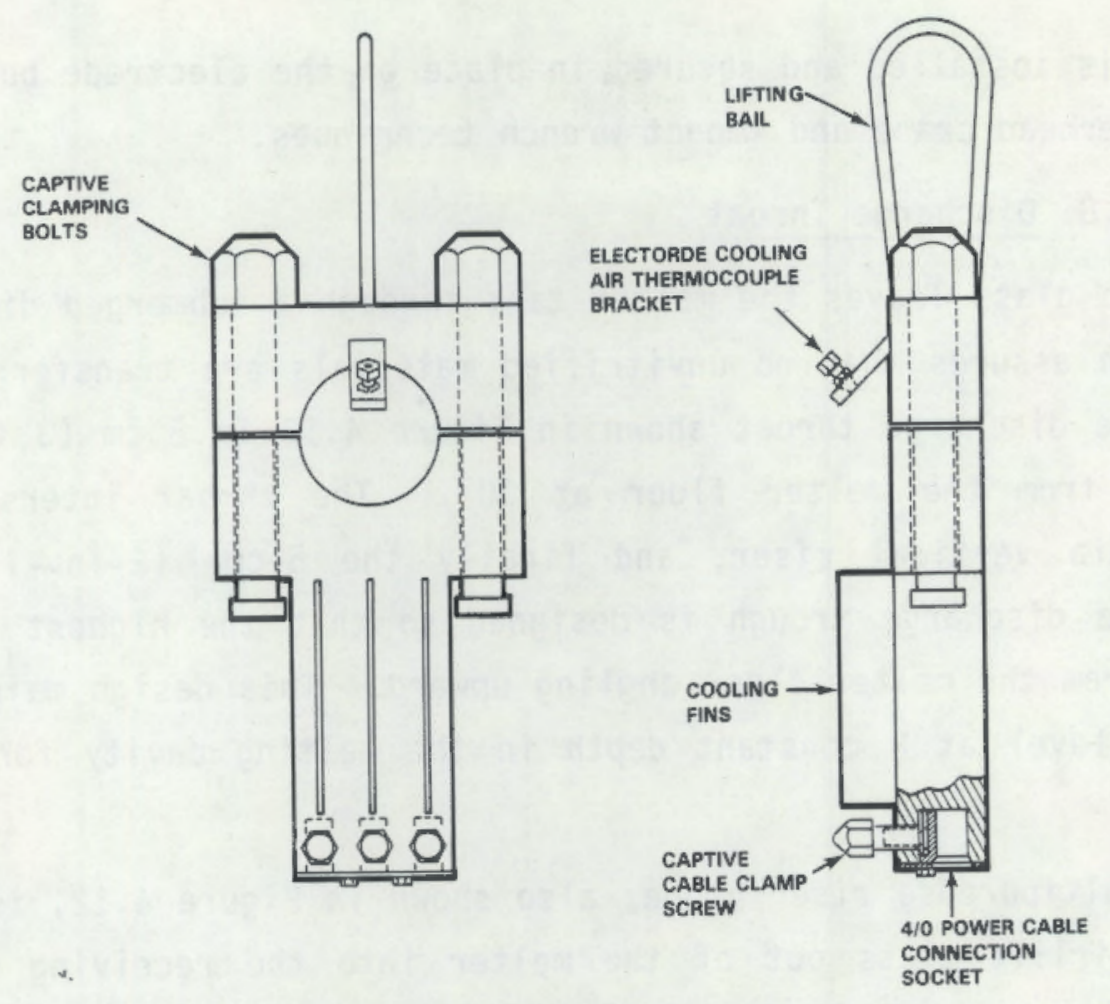

FIGURE 4.11. Electrode Power Cable Connector

cable copper conductors. This forces the conductors together and up against the side of the socket. The flattened wedge exerts its maximum force over a 1.8-cm (3/4-in.) axial length of the cable in the middle of the socket, compressing the copper strands to a bulk density of about $95 \%$ of maximum. A direct electrical contact of about $13 \mathrm{~cm}^{2}\left(2 \mathrm{in.}{ }^{2}\right)$ of the compressed copper with the Inconel connector is realized in the socket for each conductor, $40 \mathrm{~cm}^{2}$ (6 in. ${ }^{2}$ ) total for the three connectors. Some additional secondary contact is realized through the shoe, the machine screw foot, and the machine screw threads to the Inconel connector. No coating or plating has been added to either the power cable socket or to the stripped power cable conductors, al though the socket surface was machined to a mirror finish.

The power cables are trimmed and the insulation is cut and stripped from the power cables by manipulator with the aid of a special trimming tool. The cables are inserted into the connector sockets, and the socket screws are tightened with a manipulator at the viewing window. The assembled power 
connector is installed and secured in place on the electrode bus bar using the in-cell overhead crane and impact wrench techniques.

\subsubsection{Discharge Throat}

Molten glass leaves the melter tank through a submerged discharge throat. This design assures that no unvitrified materials are transferred to the canister. The discharge throat shown in Figure 4.12 is $8 \mathrm{~cm}$ ( 3 in.) in dia and angles up from the melter floor at $30^{\circ}$. The throat intersects the 5-cm(2-in.-) dia vertical riser, and finally the 5-cm- (2-in.-) dia discharge trough. The discharge trough is designed so that the highest point is $36 \mathrm{~cm}$ (14 in.) from the melter floor angling upward. This design maintains the melter glass level at a constant depth in the melting cavity for smooth melter operation.

The multipurpose riser probe, also shown in Figure 4.12, is used periodically to airlift glass out of the melter into the receiving canister. The probe also contains a thermowell to enable monitoring of the riser glass temperature and two dip legs. The two dip legs are located $0.6 \mathrm{~cm}(1 / 4 \mathrm{in.})$ and $5 \mathrm{~cm}$ (2 in.) below the discharge passage weir, and are used to indicate the presence or absence of molten glass at these levels when the airlift system is not in operation.

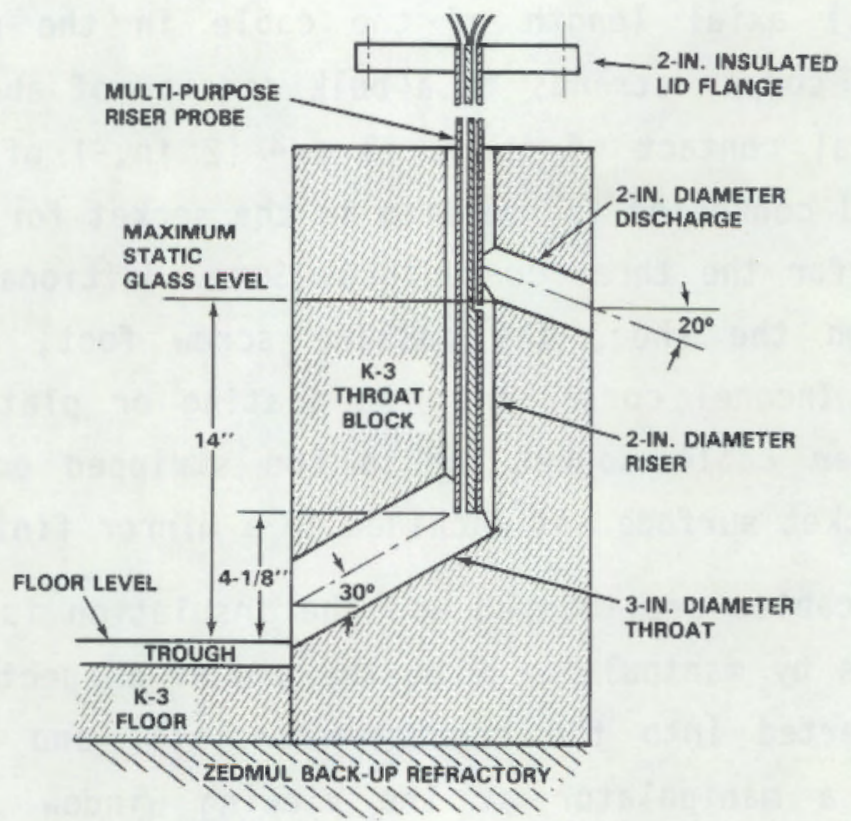

FIGURE 4.12. Submerged Throat Block and Riser Probe 
Three inner-refractory coolers are located behind the throat block on either side and below. These are 2-in.- (5- cm) thick, serpentine-baffled tanks intended to stop any glass migration past the throat block. Inlet air flow and temperature and exhaust temperature indications are used to calculate the heat losses from these coolers. Cooling air flow is controlled by manual positioning of the air flow control valve.

4.4.1.9 Discharge Trough

The discharge trough is fabricated from an Inconel-690 block that is $15 \mathrm{~cm}$ (6 in.) thick, $25 \mathrm{~cm}$ (10 in.) tall, and $43 \mathrm{~cm}$ (17 in.) long. The discharge trough is a $5-\mathrm{cm}-\left(2-i n_{.}-\right)$dia passage drilled through the block at an angle of $20^{\circ}$. This angle matches the discharge passage in the $K-3$ throat block. An enclosed passage was chosen, rather than an open trough, to preclude trough obstructions by materials falling into the discharge area during remote maintenance procedures. The discharge lip of the trough has a single low point to collect the glass before it falls to the canister. The contact surfaces between the discharge block and the Inconel discharge trough were machined to obtain a close-fitting joint and minimize glass migration from this point.

A 5-mm- (3/16-in.-) thick Inconel-690 plate is welded to the Inconel-690 discharge trough to eliminate any possibility of glass leakage into the discharge section. This plate, or dam, is rectangular and extends from the horizontal centerline of the discharge passage to within $10 \mathrm{~cm}$ (4 in.) of the containment vessel floor and walls. The dam is surrounded by castable refractories. The dam surface is treated to prevent adhesion of these castables so the dam is free to move radially with temperature changes without inducing additional tensile stresses in the surrounding refractory.

The three inner refractory coolers are parallel to the dam and separated by $2.5 \mathrm{~cm}(1 \mathrm{in.})$. These coolers maintain the outer edges of the dam below the glass softening temperature to prevent glass penetrations to the discharge cavity. The dam is electrically isolated from the inner refractory coolers.

\subsubsection{Discharge Section}

Six silicon carbide electrical resistance heaters are positioned in the discharge section. These heaters maintain the discharge trough temperature at 
$1050 \pm 50^{\circ} \mathrm{C}$ to assure proper glass pouring characteristics. The heaters are arranged in a circular array around the pouring tip. The insulating refractories are arranged in a similar circular pattern.

This design enables all of the heaters to operate in about the same temperature environment. The heated space and the discharge section heat losses are minimized as well.

The six heaters are wired in symmetric pairs, forming three heater circuits. The heaters in each circuit are connected in parallel. A redundant pair of thermocouples provide temperature feedback for each of three heater control 10ops, one for each heater circuit.

As the glass free-falls from the discharge trough lip, it passes through two concentric tubes. The outer discharge tube is welded to the containment vessel floor and extends above the Alfrax B1-57 in the discharge section. The inner discharge tube was inserted from the canister turntable below the melter. The projection of the outer discharge tube above the discharge section floor prevents broken pieces of silicon carbide heaters from falling into the receiving canister where they might obstruct the glass flow into the canister. Should one of the heaters break, the pieces can be removed by a special grapple after the discharge section lid has been removed.

The inner discharge tube is designed to be replaceable so that any obstructions in the passage between the melter and the canister can be removed. This tube is also tapered away from the melter to minimize the potential for forming an obstruction.

The inner discharge tube shown in Figure 4.13 can be remotely installed and removed by using the discharge tube handling tool (Figure 4.13). The tool consists of an air piston mounted vertically inside a cylinder that is retracted when it is rotated in the turntable. The cylinder is extended after it is positioned under the discharge section to raise a discharge tube into place or to remove a discharge tube.

The discharge tube is installed in the following sequence. The tool, with attached air hoses, is lowered into the canister liner through the access port. The discharge tube is placed on the tool and the air cylinder is 

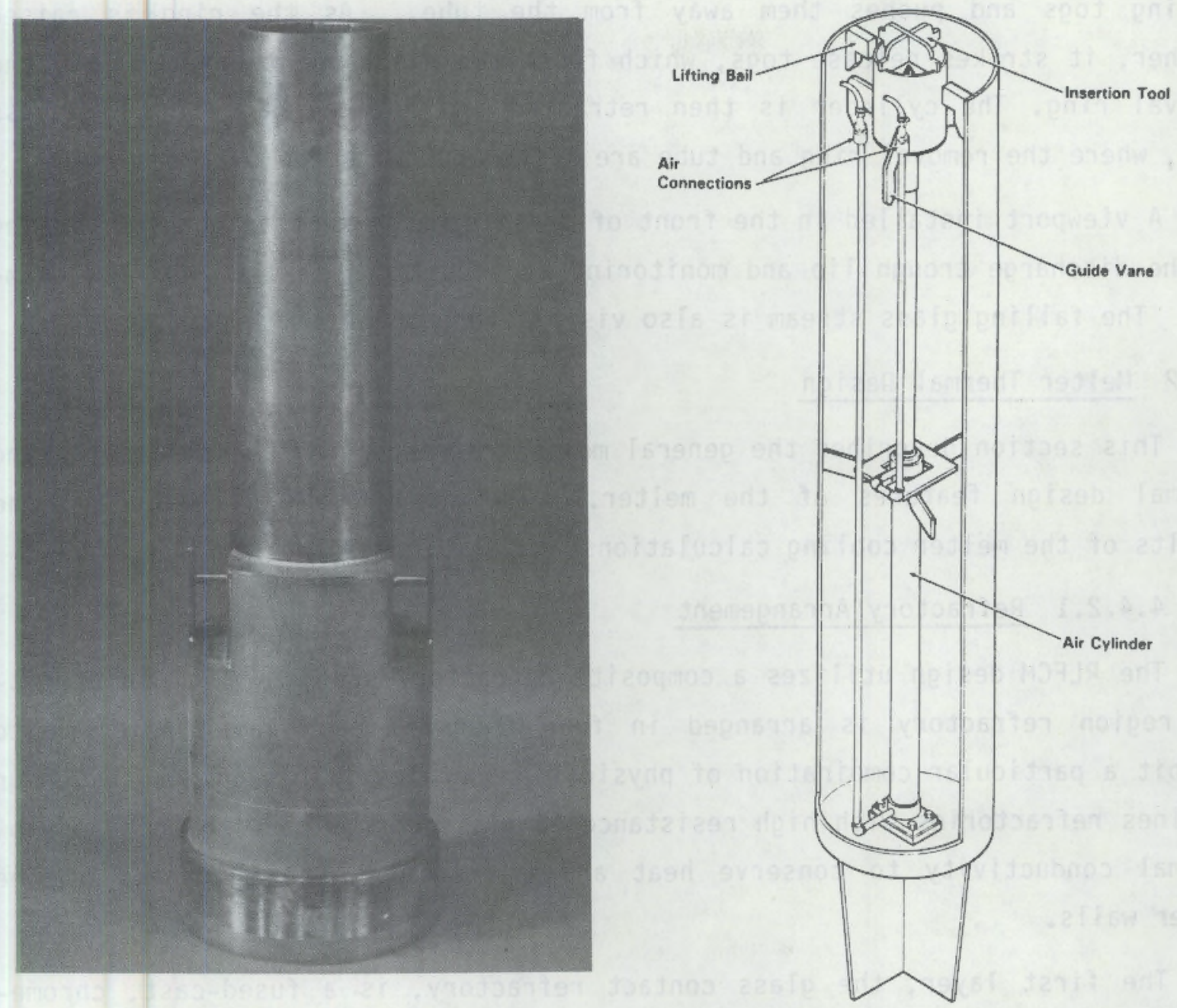

FIGIJRE 4.13. Discharge Cone and Handling Equipment

retracted. After the tool is rotated underneath the melter discharge port, the air cylinder is extended, which raises the discharge tube into the melter discharge section. The tube is guided into the permanent discharge section by the release-tog supports located at its base. The upward force of the tube activates three locking togs that clamp the tube in place. Then the cylinder is retracted and rotated back to the access port where the tool is lifted out with the overhead crane.

The discharge tuhe is removed in a similar sequence, except that a removal ring is placed on the tool for this operation. When the extended air cylinder raises the removal ring underneath the discharge tube, it strikes the three 
locking togs and pushes them away from the tube. As the ring is raised further, it strikes release togs, which force the discharge tube down into the removal ring. The cylinder is then retracted and rotated back to the access port, where the removal ring and tube are lifted out with the overhead crane.

A viewport installed in the front of the discharge section enables viewing of the discharge trough lip and monitoring of conditions in the overflow chamber. The falling glass stream is also visible through this viewport.

\section{4.? Melter Thermal Design}

This section describes the general melter refractory design philosophy and thermal design features of the melter. The assumptions, procedures, and results of the melter cooling calculations are also presented.

\subsubsection{Refractory Arrangement}

The RLFCM design utilizes a composite refractory scheme. The glass melting region refractory is arranged in four courses, each layer selected to exhibit a particular combination of physical properties. This composite design combines refractories with high resistance to glass corrosion with those of low thermal conductivity to conserve heat and to minimize the thickness of the melter walls.

The first layer, the glass contact refractory, is a fused-cast, chromealumina ceramic. Behind this layer are successive layers of a sintered alumina-zirconia-silica (AZS) material; a high alumina, castable refractory; and a ceramic fiberboard next to the containment vessel. The melter discharge section and lids are composed of two refractory layers: an alumina castable exposed to the melter plenum, backed by the fiberboard.

The glass contact refractory combines Monofrax K-3 and Monofrax E. These materials were selected because of to their demonstrated resistance to glass corrosion. Experience in the LFCM at PNL showed the corrosion rate of $K-3$ to be $23 \mu \mathrm{m} / \mathrm{d}$ over a three-year period (Barnes and Larson 1981). Due to the higher percentage of chromia in Monofrax $E(80 \%$ versus $27 \%$ in $K-3)$, its corrosion rate is expected to be lower than $\mathrm{K}-3$. Monofrax $\mathrm{K}-3$ is used along the 
melter floor and on the walls between the electrodes. Type $E$ is used only behind the electrodes in this melter due to its relatively high electrical conductivity.

A bonded AZS refractory, Zedmul, was selected for use behind the chromiaalumina layer because its thermal conductivity is roughly half that of $\mathrm{K}-3$ and it is also very resistant to glass attack. It is routinely used as the glass contact refractory by the commercial glass industry where the coloration potential of $K-3$ or $E$ makes these compositions unacceptable. PNL experience has shown that negligible corrosion of the Zedmul layer will occur over the life of the melter.

The next layer, a monolithic casting of a high-alumina ceramic (Alfrax 66 and 81-57), provides three advantages at this position in this melter refractory design. The Alfrax's are inherently less thermally conductive than Zedmul; monolithic, wall and lid castings can be fabricated because of the nature of the material; and the lower resistance to glass corrosion of the Alfrax (relative to the $\mathrm{K}-3$ and Zedmul) can be used to stop glass migration. Previous melter experience has shown that Alfrax 66 stops the migration of glass through small cracks at temperatures between 500 and $600^{\circ} \mathrm{C}$. The glass migration is stopped because the corrosion product formed as the glass dissolves this Alfrax is an alumina-saturated, high-viscosity, devitrified material. The high viscosity nature of this material makes it very difficult to wick through cracks in the Alfrax.

The final layer, ceramic fiberboard, provides both very low thermal conductivities and an easily compressed region in the melter wall. The compressability of the fiberboard accommodates the thermal expansion of the refractories.

\subsubsection{Melter Cooling Requirements}

The RLFCM was designed for natural convection and radiative external cooling. This passive mode of external cooling was selected because it eliminates the monitoring requirements of a cooling loop, minimizes thermal 
stresses in the refractory, and avoids the possibility of glass migration to the shell that could occur as a result of a cooling system failure in an alternate design.

Cooling circuits were installed inside the melter shell in the electrodes and between the melting cavity and the discharge section. Experience indicates that the electrode operating temperature should be maintained below $1100^{\circ} \mathrm{C}$ to achieve good long-term corrosion resistance although the maximum glass temperature criteria is $1300^{\circ} \mathrm{C}$.

Three cooling assemblies were placed between the melting cavity and the glass discharge. These coolers were placed along the bottom and side edges of an Inconel plate that is located between those two melter regions. The plate serves as a dam to prevent glass migration into the discharge area, and the coolers prevent the glass from wicking around the edges of the dam.

\subsubsection{Predicted Thermal Behavior}

Selection of materials for the melter features that were dictated by thermal criteria was enhanced by the use of mathematically predicted thermal behavior of those materials during the design phase. Flectrode design, refractory thicknesses, insulation and cooling systems were designed using a combination of one-dimensional and quasi-three-dimensional heat transfer calculations. These calculations were confirmed using the three-dimensional heat transfer computer code, ANSYS.

The quasi-three-dimensional calculations were performed using onedimensional, rectilinear heat transfer equations modified for the design of each melter wall so that the heat transfer area was allowed to expand as the thermal energy was transferred from the glass, through the walls, to the cell. The proper area expansion was refined using the computer simulations.

The thermal designs of the melter walls, floor, lids, electrodes, and internal cooling systems are discussed individually in the following sections.

\subsubsection{Back Wall and Floor of the Melter}

These two refractory zones of the melting cavity were designed for compatibility with a bulk glass temperature of $1300^{\circ} \mathrm{C}$ and glass viscosity of 
100 poise. Natural convection was assumed from the glass to the refractory where applicable, and radiative heat transfer, at idling conditions, was assumed for the areas above the glass. Temperature limitations were $200^{\circ} \mathrm{C}$ maximum at the outside of the melter shel1, $750^{\circ} \mathrm{C}$ maximum at the $\mathrm{Alfrax} /$ Zedmul interface, and a $500^{\circ} \mathrm{C}$ maximum temperature at the front face of the Duraboard.

The refractory makeup for the melter floor and the back wall (wall opposite the overflow drain) are listed in Table 4.2. The high density alumina castable Alfrax 66 was placed below the glass level, and lower density Alfrax B1-57 was placed above the glass.

TABLE 4.2. Refractory Configuration of the Floor and Back Wall of the Melter

\begin{tabular}{|c|c|c|c|c|}
\hline \multirow[b]{2}{*}{ Region } & \multicolumn{2}{|c|}{ Refracto } & Thickness & nches \\
\hline & $k-3$ & Zedmul & $\begin{array}{l}\text { Alumina } \\
\text { Castable }\end{array}$ & Duraboard \\
\hline $\begin{array}{l}\text { Floor } \\
\text { Back Wall }\end{array}$ & $\begin{array}{l}3-4 \\
4\end{array}$ & $\begin{array}{l}7 \\
6\end{array}$ & $\begin{array}{l}5.5 \\
3\end{array}$ & $\begin{array}{l}0.5 \\
0.3\end{array}$ \\
\hline
\end{tabular}

These refractory dimensions meet the required temperature criteria listed above, and maintain the melter shell below $200^{\circ} \mathrm{C}$ at the maximum glass temperature $\left(1300^{\circ} \mathrm{C}\right)$.

The computer-predicted temperature profiles for the centerline of these two regions are shown in Figure 4.14. Figure 4.15 shows predicted temperature profiles for the electrode walls, and assumes a bulk glass temperature of $1300^{\circ} \mathrm{C}$. The electrodes are maintained at $1100^{\circ} \mathrm{C}$ in these plots, and the inner refractory cooler temperatures are $400^{\circ} \mathrm{C}$. The bottom surface shown in the temperature plots is the Alfrax/Fiberboard interface, not the bottom surface of the melter shell. The temperature at the outer surface of the shell along the back wall is less than $200^{\circ} \mathrm{C}$. The temperature profiles in this region are very compressed in the fiberboard layer and have been omitted for clarity.

\subsubsection{Melter Lid}

The refractory design for the melter lid uses a combination of $12.7 \mathrm{~cm}$ ( 5 in.) of Alfrax 66 and $10 \mathrm{~cm}$ (4 in.) of Duraboard. 

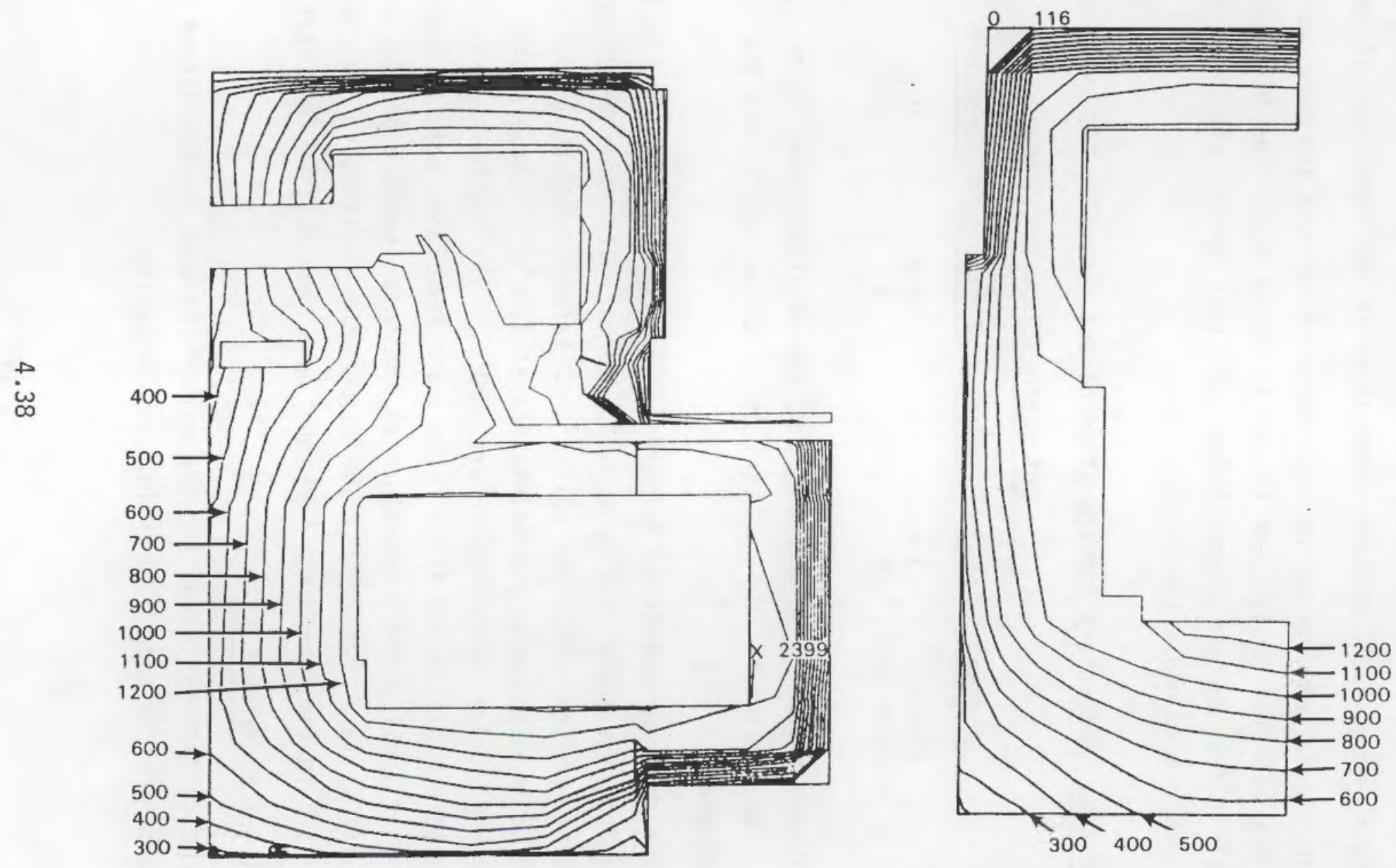

FIGURE 4.14. Centerline Computer-Predicted Temperature Profiles for the Back Wall and Floor of the Melter

FIGURE 4.15. Predicted Temperature Profiles for Electrode Walls 
Using this refractory configuration, the external surface temperatures for both the sides and top of the melter lid were estimated. The external temperature of the longer pair of the lid walls was calculated by balancing the external natural convective and radiative losses with the quasi-three-dimensional conduction of heat through the refractory. The internal surface of the lid was assumed to be $1300^{\circ} \mathrm{C}$. The analysis predicted that the external surface temperature would be approximately $120^{\circ} \mathrm{C}$. As the shorter sides have a larger external/internal surface area ratio than the longer sides, an even lower external temperature is expected.

The external surface temperature for the upper lid surface was calculated to be roughly $215^{\circ} \mathrm{C}$. Although this exceeds the $200^{\circ} \mathrm{C}$ limit of the design criteria, the assumptions used in the analysis are very conservative; thus, the $215^{\circ} \mathrm{C}$ is considered an upper 1 imit.

Two assumptions were used in this analysis. First, the penetrations through the lid were treated as open holes and the glass (at $1300^{\circ} \mathrm{C}$ ) was allowed to radiate to a disk (at $35^{\circ} \mathrm{C}$ ) the size of the penetration at the upper lid surface. This radiative heat transfer was added to the conductive heat transfer through the refractory and the total was assumed to be lost from the lid surface.

Second, the presence of flanges and other paraphenalia on the lid surface is expected to effect the heat transfer from the lid surface. This effect will be complicated, as these objects will interfere with convective and radiative losses from the lid surface, but they will also act as fins, thus aiding in cooling the surface. For this analysis, the flanges are assumed to reduce the cooling of the lid by $1 / 3$, and no credit for the cooling fin effects is included.

\subsubsection{Electrodes and the Electrode Wall}

The Inconel-690 electrodes have an upper operating temperature limit of $1100^{\circ} \mathrm{C}$ to prevent corrosion and require cooling due to the $1300^{\circ} \mathrm{C}$ maximum glass temperature design criteria. A direct, forced-air electrode cooling system was selected because it provided the maximum flexibility for the melter operator. 
The electrode cooling calculations assumed a $1300^{\circ} \mathrm{C}$ bulk glass temperature at idling conditions and assumed that all of the heat transferred to the electrode by convection and radiation would have to be removed by the electrode cooling system because no heat losses to the electrode wall were assumed.

These calculations showed that a $2.54 \mathrm{~cm} \times 2.54 \mathrm{~cm}$ cooling channel machined into the back of the electrodes in a serpentine fashion would provide adequate cooling to meet the design criteria. The nominal spacing requirements between adjacent cooling channels was found to be $2.54 \mathrm{~cm}$. The cooling calculations predict that 96 scfm of air will be required to cool each electrode at the maximum temperature condition, and that the temperature rise of the air would be $700^{\circ} \mathrm{C}$ maximum. The pressure drop across each cooling system will not exceed 15 psig.

The electrode wall refractory was designed so that the electrodes could be maintained at or below $1100^{\circ} \mathrm{C}$ by external natural convection and radiation cooling should one of the electrode cooling loops fail. These calculations assumed that the glass temperature would be controlled to maintain the electrodes at or below $1100^{\circ} \mathrm{C}$. The calculation procedure was similar to that used for the melter floor and back wall, and showed that $3 \mathrm{in}$. of Monofirax E, 3 in. of Zedmul, $4 \mathrm{in}$. of Alfrax 66 , and $0.3 \mathrm{in}$. of Duraboard would be required for these walls.

The temperature profiles predicted by the computer model for the electrode walls are shown in Figure 4.15. The computer assigned $1100^{\circ} \mathrm{C}$ to each of the electrodes and $1300^{\circ} \mathrm{C}$ as the glass temperature. The bottom surface of the profile is at the Alfrax 66/Duraboard interface, and does not represent the temperature of the outside of the shell along the melter floor.

\subsubsection{Discharge Section Cooling}

Three cooling assemblies are located between the melting cavity and the discharge region of the melter. The two along the side of the melter are the inner refractory coolers (IRC). The subrefractory cooler (SRC) is positioned across the melter floor.

The thermal calculations for these coolers took into account their position in the melter relative to the "through-the-electrodes" melter centerline. 
Because the position of the coolers is nearly symmetrical on this centerline to the external surface of the melter back wall, the heat flux entering the coolers from the melting cavity was assumed to equal the heat flux leaving the back wall. Also, a heat flux of equal magnitude was assumed to enter these assemblies from the discharge section.

Given these assumptions, these cooling assemblies were shown to produce wall temperatures below $400^{\circ} \mathrm{C}$ at air flow rates of 13 and $17 \mathrm{scfm}$ for the IRCs and SRC, respectively. Because glass is generally assumed to stop migrating through refractory cracks in the temperature range of 500 to $600^{\circ} \mathrm{C}$, these coolers will stop glass flow around the edges of the Inconel-690 dam.

\subsubsection{Electrical System Design}

\subsubsection{Melting Cavity Dimensions}

The RLFCM design criteria specifies that the nominal feed rate for the melter will be $25 \mathrm{~L} / \mathrm{h}$. Using a conservative melting flux constant of $50 \mathrm{~L} / \mathrm{h}-\mathrm{m}^{2}$, the required melting surface area is calculated to be $0.5 \mathrm{~m}^{2}$.

The slurry-fed melters are typically operated such that the layer of reacting feed materials floating on the glass surface (cold cap) is permitted to enlarge until it just contacts one of the melting cavity refractory walls. The cold cap is maintained at this size so that no bridging of the calcined feed is possible. Bridging is undesirable because it traps the feed decomposition gases beneath the cold cap, reduces the rate of heat transfer to the feed, and, when the bridge collapses, it exposes the slurry directly to the melter glass surface. Nirect contact of the slurry and the glass leads to rapid off-gas generation and fluctuating off-gas flow rates.

Minimizing the bridging potential suggests a square glass surface; however, this generally produces unacceptably high current densities on the electrodes for melters of reasonable depth. Typical PNL melters are designed with a melting cavity length-to-width ratio of about 1.5:1. The RLFCM was designed with a length-to-width ratio of $1.3: 1$ as a compromise between the melter electrical properties and the usable glass surface area. 
Experience at PNL has shown that the melter electrodes can be operated at current densities slightly in excess of $0.77 \mathrm{~A} / \mathrm{cm}^{2}$ and still yield low corrosion rates. Also, the minimum electrical conductivity of waste glasses are typically on the order of $1\left(\Omega^{*} \mathrm{~cm}\right)^{-1}$. Using these boundary conditions and a conservative estimate of the melter power requirements $(80 \mathrm{~kW})$, the maximum depth of the melter was found to be $35.6 \mathrm{~cm}$ (14 in.). Therefore, the melting cavity dimensions are $81.3 \mathrm{~cm} \times 61.0 \mathrm{~cm} \times 35.6 \mathrm{~cm}(32 \mathrm{in} . \times 24$ in. $\times 14$ in.).

Also, it is desirable to operate the melter with the potential between the electrodes less than $200 \mathrm{~V}$ in order to minimize the possibility of arcing in the electrode power system. Using this melter geometry and the generally accepted maximum glass conductivity, $0.1\left(\Omega^{\bullet} \mathrm{cm}\right)^{-1}$, the predicted maximum electrode potential is $173 \mathrm{~V}$.

\subsubsection{Electrical Power System Sizing}

The RLFCM requires from 30 to $40 \mathrm{~kW}$ to maintain the glass melter tank at 1100 to $1150^{\circ} \mathrm{C}$ during idling conditions to balance expected heat 10 sses. At the design feed rates, 80 to $100 \mathrm{~kW}$ is required to maintain the glass at $1150^{\circ} \mathrm{C}$. Figure 4.16 shows the electrical system required to supply this power to the melter electrodes.

The single-phase melter electrode power system originates in a $480-V$, 3-phase, $60-\mathrm{Hz}, 600-\mathrm{A}$ power panel. The primary electrical protection device for this power system is a single-phase, 500-A circuit breaker. Following this

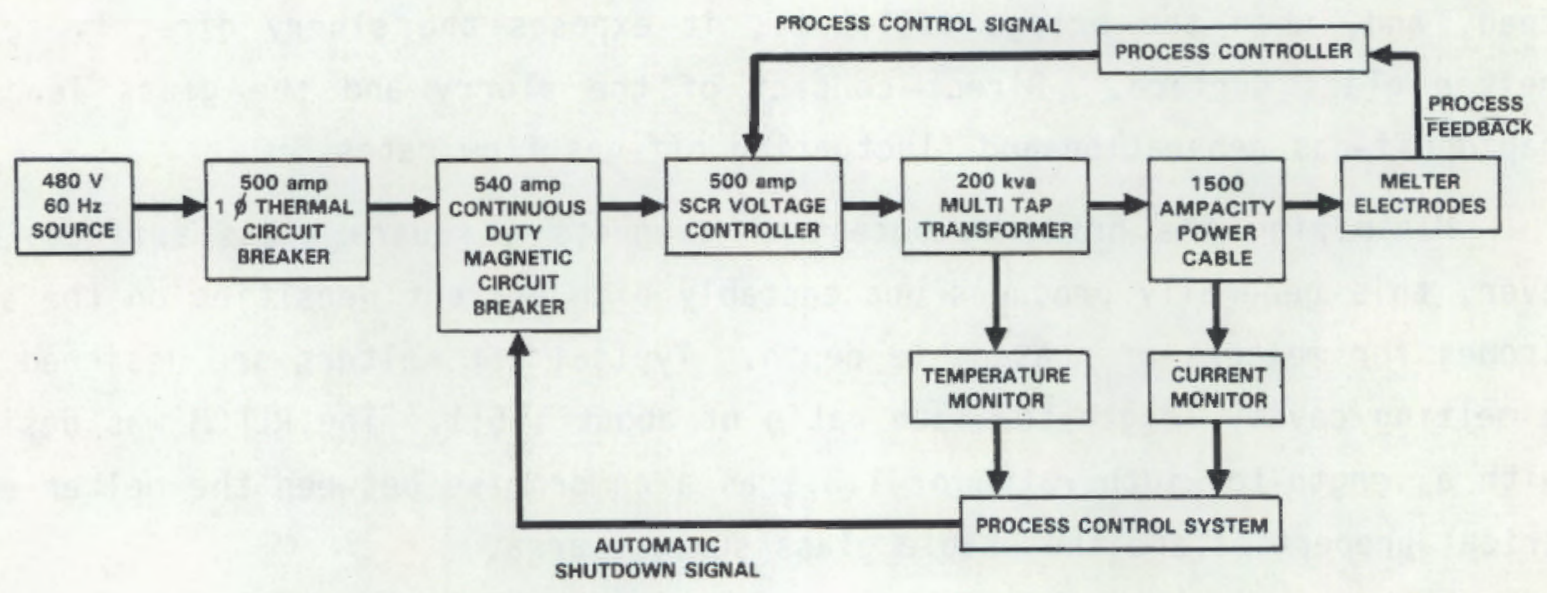

FIGURE 4.16. Power Supply for the RLFCM Electrodes 
circuit breaker is a 540-A, continuous-duty magnetic circuit breaker that is used to shut the power system down remotely.

Following the magnetic circuit breaker is a 500-A, phase-angle-fired, SCR voltage controller that will regulate the $480-\mathrm{V}$ ac power source to a linearly reduced value between 0 and $480 \mathrm{~V}$ ac in response to a 4 to $20 \mathrm{~mA}$ dc control signal, or to a manually set potentiometer. This SCR controller is equipped with a built-in output power (volts $x$ amps) feedback circuit that maintains a constant SCR power output, between 0 and $240 \mathrm{~kW}$, given a constant control signal value. The controller has a design current limit of $500 \mathrm{~A}$, and has a built-in current-limiting feature that is adjustable from 5 to $110 \%$ of this design limit.

An additional feature of the $S C R$ is a selectable output ramping speed from $30 \mathrm{msec}$ to $3.4 \mathrm{sec}$. This feature permits "soft starts," because it is designed to eliminate the initial current rush characteristic of transformers in resistive load circuits.

The modulated voltage from the SCR regulator is applied directly to the primary coil of a $200 \mathrm{kVA}$, step-down, power transformer. The transformer output is totally isolated from the input and from ground, and tapped to realize step-down ratios of $75,50,33$ and $20 \%$ of the input modulated voltage. With a $480 \mathrm{~V}$ ac input, the $200 \mathrm{kVA}$ primary is limited to $417 \mathrm{~A}$. To protect the transformer primary from overcurrent damage, the current-limiting feature of the SCR voltage regulator is used with an $83.3 \%$ setting for a maximum current output of 417 A. With the SCR and the step-down power transformer combination, electrode voltage ranges of 0 to 360,0 to 240,0 to 160 , and 0 to $96 \mathrm{~V}$ ac are available. Likewise, with this system and the 417 A limited SCR, electrode current ranges of 0 to 556,0 to 834,0 to 1263 , and 0 to $2085 \mathrm{~A}$ are also possible.

The voltage and current characteristics of the 500-A SCR/200-kVA transformer system are shown in Figure 4.17. Superimposed on these characteristics are the anticipated power range requirements for the melter. As shown, all of the anticipated normal melter operating ranges are within the capabilities of the transformer, and some capacity for either range extension or operation at less than limiting conditions is provided. 


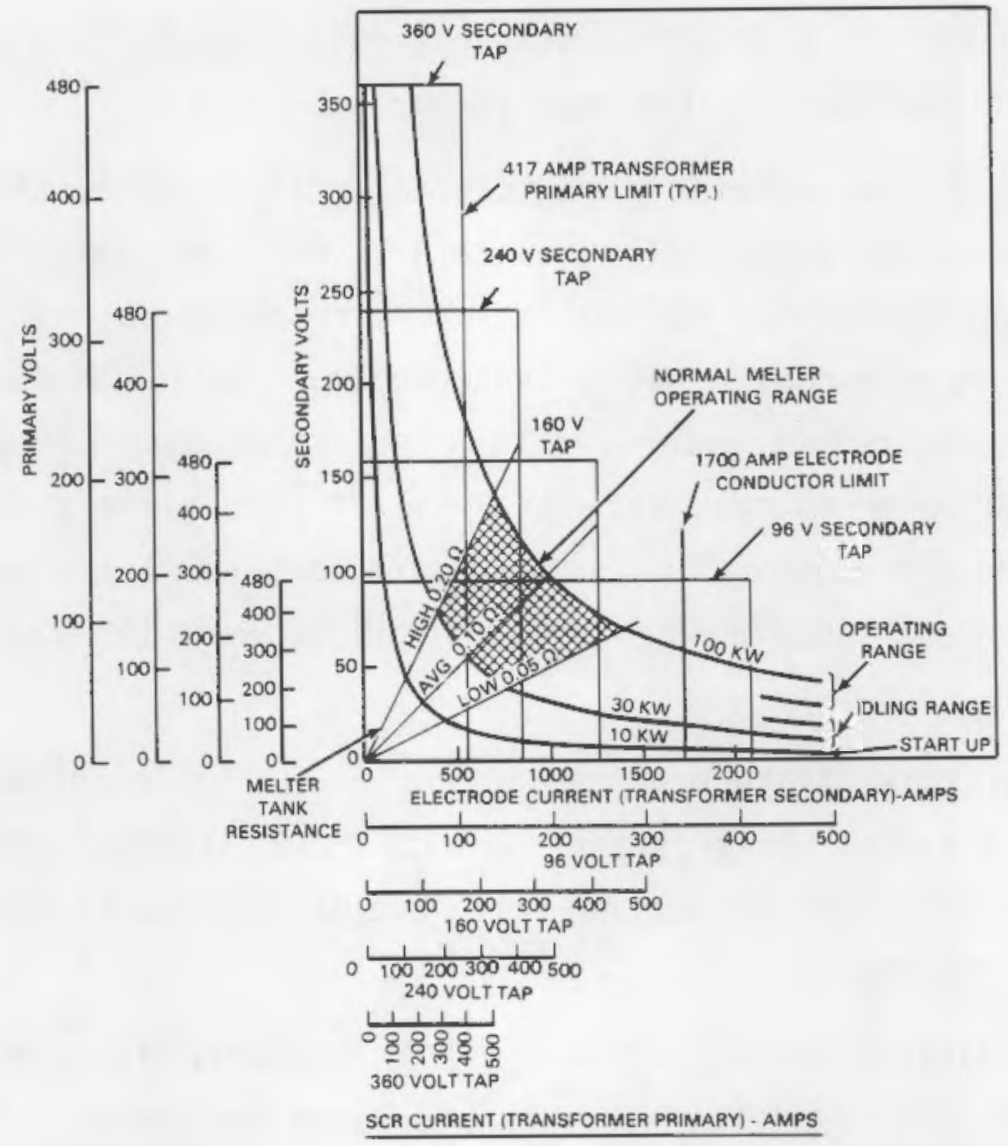

FIGURE 4.17. 500 Amp SCR/200 kVA Transformer Electrical Characteristics

The 1981 National Electric Code recommends that the circuit breaker protecting the primary of a transformer be rated at the next larger standard size above $125 \%$ of the primary coil rating, allowing for the transformer inrush current to occur when the transformer is initially energized without tripping the circuit breaker. Thus, for a 200-kVA transformer with a $480-V$ input, the appropriate breaker would be $417 \mathrm{~A} \times 1.25$ or $521 \mathrm{~A}$. The next larger circuit breaker is $600 \mathrm{~A}$, which would be too high to protect the 500-A SCR in the primary circuit. The controlled power ramping speed feature of the SCR is used to limit the transformer in rush current, which protects the 500 A SCR circuitry.

Fatigue failure of circuit breakers is avoided by use of a size large enough to require operation continuously at $85 \%$ of its trip value. Therefore, a 500-A circuit breaker can be operated continuously at $500 \times 0.85$ or $425 \mathrm{~A}$. 
This is slightly over the transformer's primary circuit current rating of 417 A. Also, with the SCR "soft-start" feature to suppress the transformer inrush current, both the power transformer and the SCR voltage regulator are protected.

Although this discussion bases the protection of the power transformer on its primary circuit current rating, this is not necessarily always the cause of transformer failure. A transformer may fail because of an insulation failure, most often caused by excessive temperature transients. Although the temperature excursions can be caused by exceeding the transformer current rating, other causes, such as from electrical contact, also raise the transformer temperature. As a backup to the SCR output current-limiting capability, four thermocouples have been built into the power transformer; two in the primary coil and two in the secondary winding. These thermocouples have been positioned in the characteristic "hot spots" of both windings, and are monitored by the process control system. The temperatures indicated by these thermocouples are routinely logged for operator surveillance, and are available on demand. In addition, each thermocouple indication is connected to an audible alarm system that will alert operating personnel when the temperature approaches limiting operating conditions. Finally, upon an over-temperature indication, the process control system will automatically open the magnetic contactor in the SCR input circuit and shut down the electrode power supply system.

The normal melter operating range as shown on Figure 4.17 is within the capabilities of the $160-V$ ac power transformer tap. During startup procedures, and possibly with some differing composition feeds, some shifting from one tap to another may be required. The power transformer that will be used has a large, manually-operated, tap-changing switch located on the transformer. Because the transformer may be damaged if this tap is changed under load, several precautions will be taken. A red lamp will be lighted when the transformer is powered, and the operator is instructed not to change the tap position if the lamp is lighted. A switch in the control room at the operator control console can open the magnetic contactor in the $480-V$ ac power supply to the SCR voltage regulator, shutting down the power to the transformer. A similar switch on the cell wall at the melter level can also be used by an operator 
to shut off the power to the SCR. A similar switch, located near the transformer, can be used to shut the transformer down by the operator who is going to make the tap change. Finally, the tap-change lever is held in position by a trigger-operated pawl, and a switch mounted on this trigger will also open the contactor in the SCR circuit permitting the tap change to be made safely. The magnetic contactor can only be closed and reset by a single "on" button located on the operator control console.

Power from the power transformer is routed through six $\# 4 / 0$, extra flexible power cables to the electrode bus bars, each of which has three cables. Cable flexibility is required because the cable-to-electrode bus bar connectors are made up and maintained by manipulator at the window, and then moved for installation on the bus bars by an overhead crane. The cables are insulated with silicone rubber, with a glass yarn outer jacket. The insulation is rated for a minimum of $200^{\circ} \mathrm{C}$, raising the ampacity of each cable to $570 \mathrm{~A}$, based on a copper temperature of $200^{\circ} \mathrm{C}$.

\subsubsection{RLFCM Operation and Control}

The function of the RLFCM is to vitrify an aqueous waste/glass-former slurry. and to discharge the resultant molten glass into a receiving canister. The heat required to evaporate the water from the slurry, to calcine the resultant chemical forms to oxides, and to fuse these oxides into a glassy matrix is generated by passing alternating electric current through the molten glass mixture.

The operating characteristics of the melter will be affected by the temperature of the molten glass in the tank. If the glass temperatures greatly exceed design conditions, glass components will begin to volatilize and accumulate in the off-gas system, and the melter refractory components will be excessively corroded. If the glass temperatures are too low, the glass viscosity will rise to unacceptable levels. High glass viscosity slows down the melting process, interferes with proper pouring of the glass from the melter, and leads to excessive void formation in the receiving canister. Thus, the prime purpose for the electrode power control system is to maintain the proper processing temperature in the melter as the slurry feed rate, glass level, and slurry composition vary. 
In general, the RLFCM will be controlled using constant resistance feedback (Figure 4.18). Because the electrical resistance of the waste glasses is a strong function of the bulk glass temperature, this is a good method of controlling the melter temperature. Constant resistance control is achieved by determining the melter resistance from the electrode voltage and current values $(R=E / I)$, and using this value for the feedback signal. For this system, the only calibration data required are a relationship between the melter tank resistance and the glass temperature for the specific melter and glass composition being produced. Experience has shown that over a span of 100 to $200^{\circ} \mathrm{C}$, the relationship between the melter temperature and resistance is essentially inversely linear. Thus, with this control system, assuming that the resistance set point is adjusted to realize the desired melter tank glass temperature for the present feed rate, a feed rate increase would reduce the glass temperature, causing the completed resistance to also increase. With this slight resistance increase, the control system would increase the electrode voltage slightly and the net effect would be a slight increase in power, bringing the glass temperature up and the resistance value back to its preset value.

The microprocessor-based process control loop for regulating the electrode voltage includes provisions for obtaining the calculated resistance value.

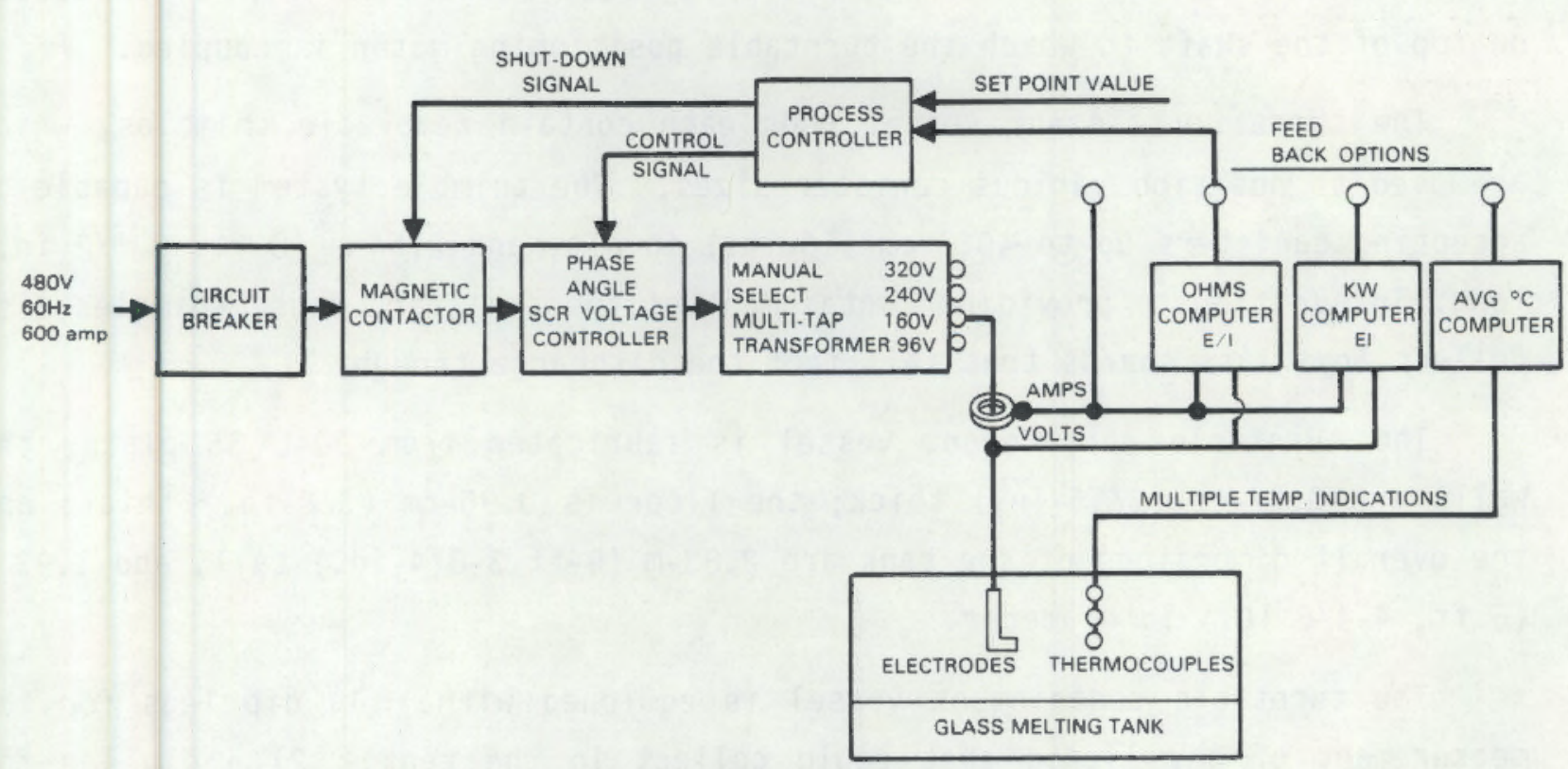

FIGURE 4.18. Process Control System for the RLFCM 
This value will be the primary feedback value for the operator to use in controlling the melting process. Alternative control systems that will be available to the melter operator for use, as appropriate, are loops for constant melter current and power feedback.

\subsection{CANISTER-HANDLING TURNTABLE}

The canister-handling turntable provides physical movement and positioning of the canisters underneath the RLFCM for canister filling and initial cooldown of the thermally hot canisters. The dunnage that supports the turntable aiso provides support for the RLFCM.

\subsubsection{Turntable Design Description}

The canister turntable, shown in Figure 3.4 and partially assembled in Figure 4.19, consists of a three-position motor-driven carousel, which is located inside a containment vessel. The carousel consists of three containment pods equally spaced around a center axis. The carousel rotates around the center shaft supported by two bearings located at the top and bottom of the shaft. The normal rotational direction of the turntable is clockwise, although the turntable can rotate in either direction. The top of the shaft extends out of the containment vessel through a bearing seal retainer. A hole is located on top of the shaft to which the turntable positioning motor is coupled.

The three containment vessel pods each contain removable thimbles, which are used to position various canister sizes. The thimble system is capable of accepting canisters up to $40.7 \mathrm{~cm}$ (16 in.) in dia, and $2.64 \mathrm{~m}(8 \mathrm{ft}, 8-1 / 2 \mathrm{in.})$ long. In addition to providing containment of the canister, these thimbles also collect any glass shards that fall from the discharge trough.

The turntable containment vessel is fabricated from $304 \mathrm{~L}$ SS plate; the walls are $0.47-\mathrm{cm}\left(3 / 16-i n_{0}\right)$ thick; the floor is $0.95-\mathrm{cm}\left(3 / 8-i n_{0}\right)$ thick; and the overall dimensions of the tank are 2.83-m (9-ft 3-3/4-in.) tall, and $1.93 \mathrm{~m}$ (6 $\mathrm{ft}, 4-1 / 8 \mathrm{in.}$ ) in diameter.

The turntable containment vessel is equipped with: 1) dip legs for the measurement of any liquid that could collect in the tank, 2) a dip leg for jetting out that solution, and 3) six thermocouples. Arranged three to a set, 


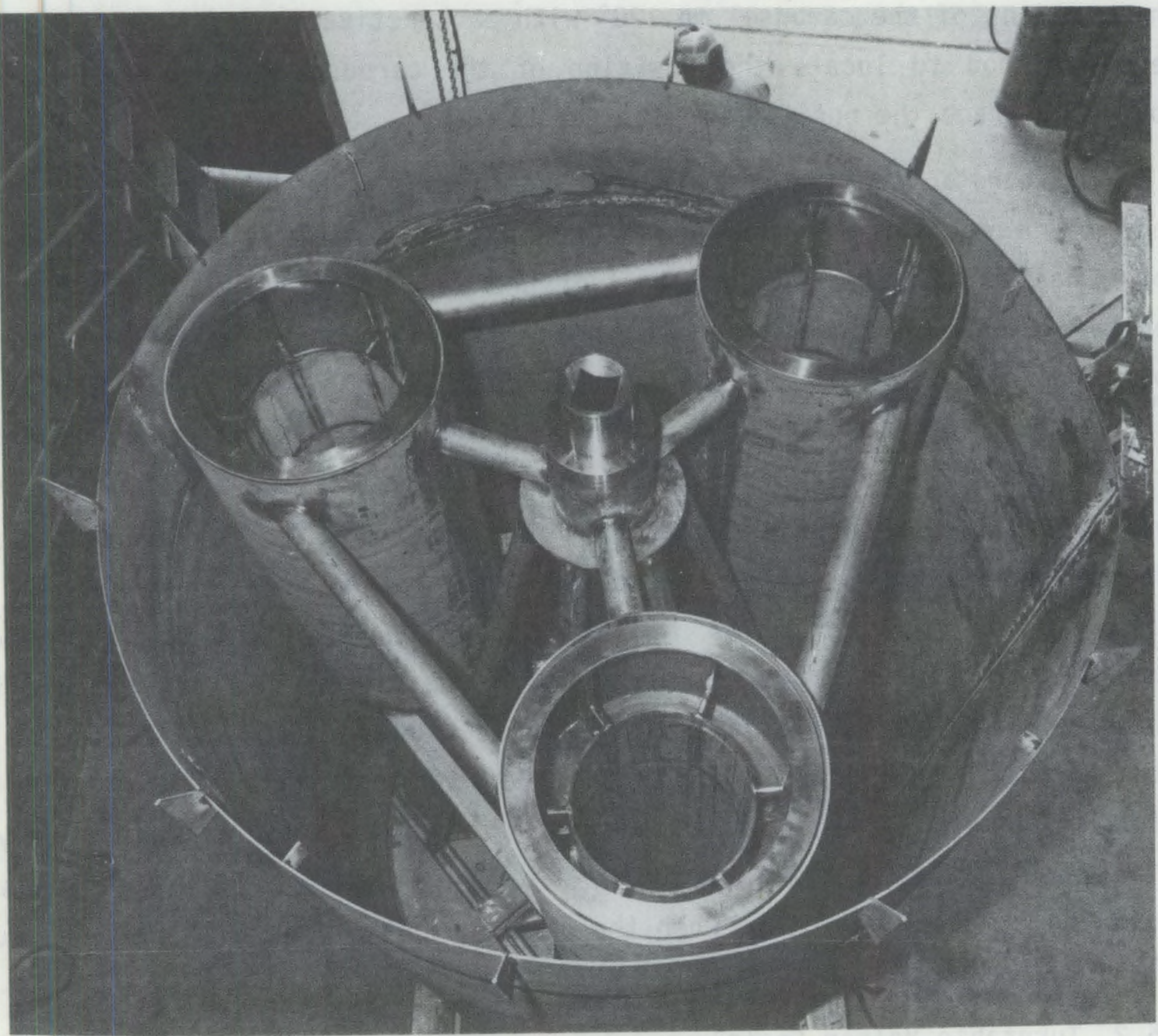

FIGURE 4.19. Canister Turntable Partially Assembled

the thermocouples are located at opposing sides of the turntable; three are located near the canister filling position and three are located near the canister cooling position. The thermocouples in each set are positioned near the top, the bottom, and midway along the turntable wall. Each set of thermocouples is located within a blister connected to the tank. At the bottom of each thermowell is a window that allows contact of the thermowell with the inside of the containment vessel.

The carousel is positioned and centered underneath the melter overflow by two methods. The primary positioning method is the use of a potentioneter attached to the carousel drive system. This system, once calibrated, limits 
the movement of the carousel to $120^{\circ}$ with each activation of the drive motor. A second method to locate the position of the carousel is using a radioactive source to trace the position of the carousel.

The turntable drive train is equipped with a 1 HP DC motor, a 3500:1 gear reducer, a mechanical cam, and a clutch set at 11,000 in.-1bs. The $1 \mathrm{HP}$ dc motor has an adjustable speed control and can be operated in a clockwise or counter clockwise direction. The gear reducer allows the drive train to be mounted directly to the turntable center axis support and allows the use of a $1 \mathrm{HP}$ motor to rotate the turntable at $\sim 0.2 \mathrm{RPM}$. The mechanical cam allows the drive motor to rotate continuously while the gear reducer output shaft only rotates $120^{\circ}$ and then pauses until the next cam engages. The pause created by the mechanical cam last 30 secs with the motor on the highest speed. The pause stops the turntable thimbles in the correct position and the potentiometer control system turns off the drive motor. The clutch in the gear unit is set to release at 11,000 in.-1bs, which is more than adequate to rotate the turntable when it is full. The clutch will disengage if something jams the turntable carousel. The clutch is engaged by spring-loaded pins that only lock into place at one setting, but the friction between the clutch plates will cause the carousel to rotate when the pins are not locked into place because it only requires $60 \mathrm{ft}-1 \mathrm{bs}$ to rotate an empty carouse1.

\subsubsection{Turntable Melter Seals}

The turntable has two primary openings; one for access to canister containers, and the other for mating of the RLFCM and the canister handiing turntable. Each of these connections is provided with a vacuum seal (Figure 4.20).

The seal-cover concept for movement of canisters into and out of the turntable is shown in Figure 4.21. The canister-removal seal uses a 24-in.deep water seal to maintain vacuum in the canister-handling turntable during normal operation. The seal consists of four basic parts: 1) a water seal trough that is an integral part of the turntable cover, 2) a removable lid, 3) a floating inner seal, and 4) a cam positioning system for moving the inner seal. During normal operation, the removable lid, which is weighted by a lead-

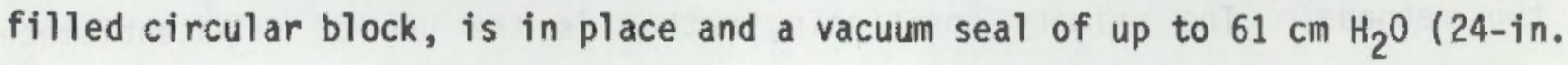




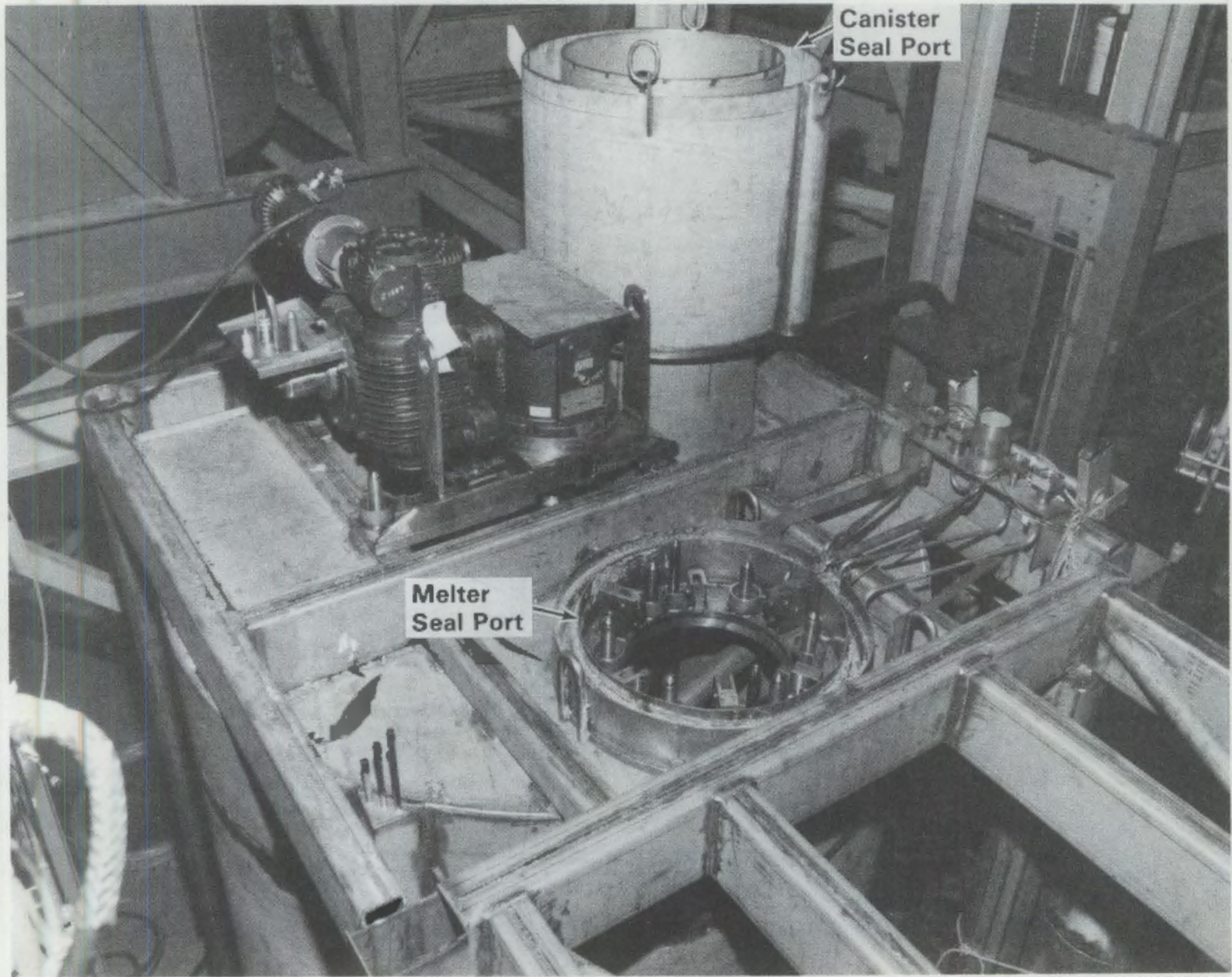

FIGURE 4.20. Turntable Ports with Vacuum Seals in Place

of water) is provided by the water seal. In the turntable port closed position, the weighted lid also lifts up, via a cam interlock of the inner seal, so that the carousel is free to rotate.

Access to the turntable is achieved by removal of the weighted 1 id; removing this lid allows the inner seal to fall. In the turntable port, open position, the inner seal and the top of the canister thimble mate and provide a temporary seal that minimizes the air leakage into the canister-handling turntable and, subsequently, air leakage into the vitrification system.

A second turntable seal is used to mate the turntable to the RLFCH. This metal seal concept is shown in Figures 4.22 and 3.4. The metal seal is comprised of three basic parts: a metal reservoir; a lip that extends down from the RLFCM containment vessel; and the seal material, which is an alloy with a 


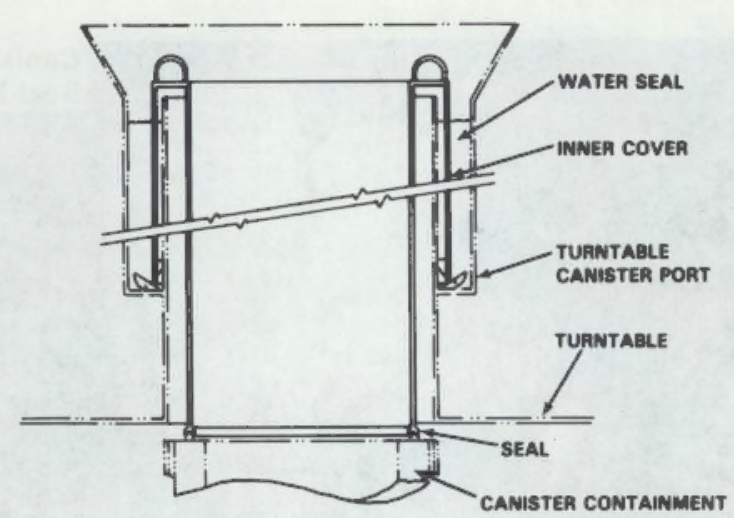

TURNTABLE PORT OPEN

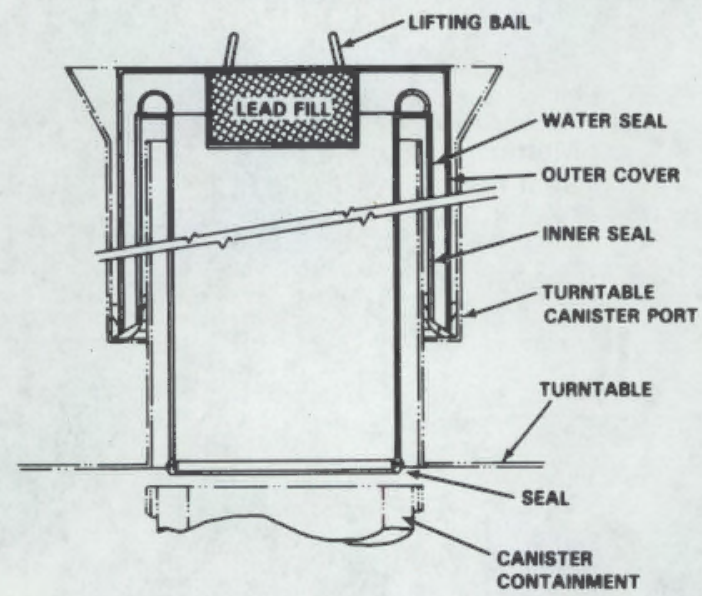

TURNTABLE PORT CLOSED

FIGURE 4.21. Positions of the Access Port on the Turntable

low melting point $\left(125^{\circ} \mathrm{C}\right)$ such as Metco 255. This seal concept was chosen because it can be remotely made or broken. The seal is of high quality and high durability compared to a mechanical seal. To make the seal, the RLFCM is positioned and bolted to the turntable. Alloy shot is placed in a steam-traced cup, which through a discharge tube feeds molten metal to the sealing trough. The liquid metal shot melts and flows from the cup into the sealing trough. The feeding of shot to the melting cup is continued until a sufficient mass of shot has been fed to the seal to achieve a predetermined seal depth. Next, the steam service is discontinued and the seal metal is allowed to solidify, forming a high-integrity seal.

During normal vitrification operations, the temperature of the area around the seal will exceed the melting point of the sealing alloy. To prevent 


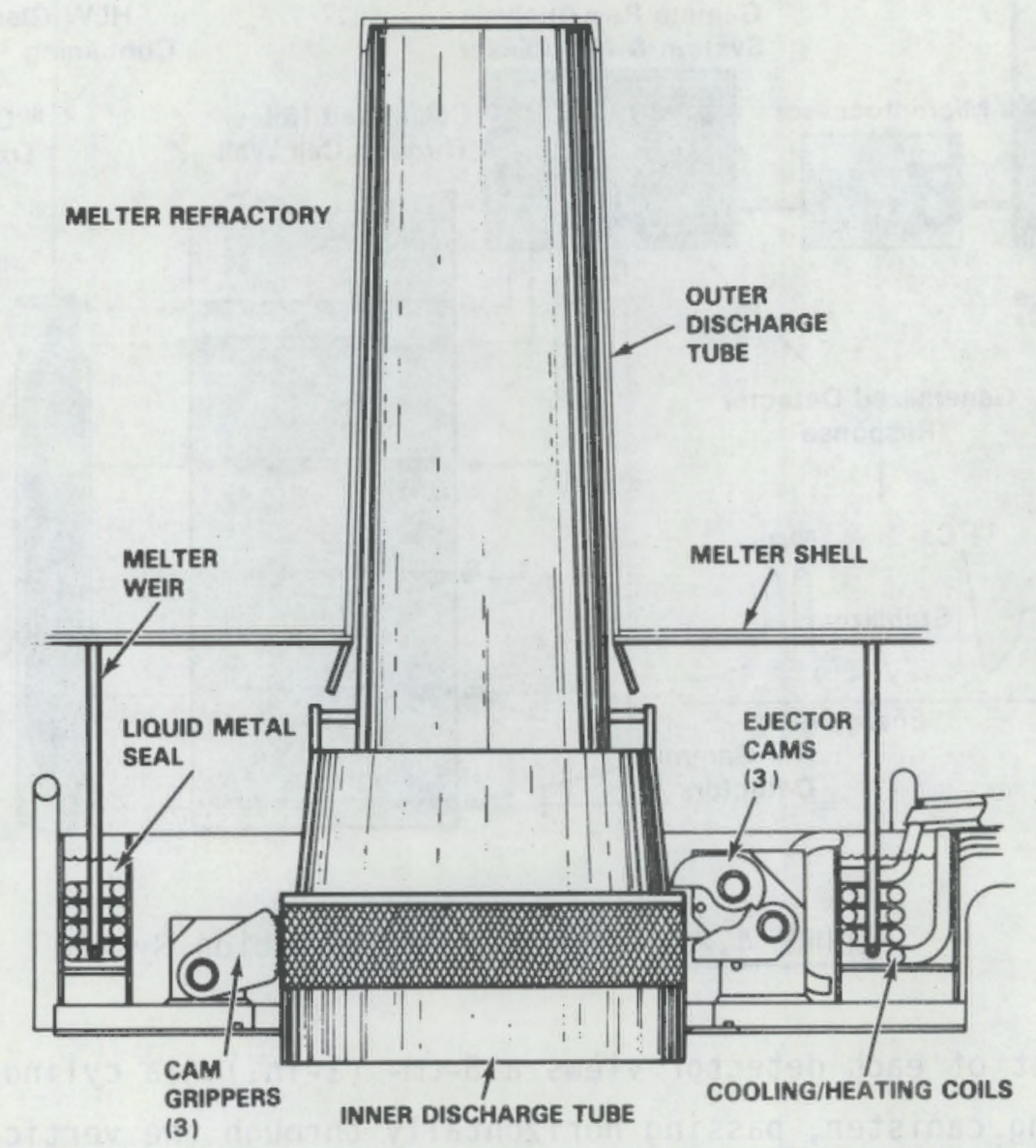

FIGURE 4.22. Metal Seal Concept for Connection of the RLFCM to the Canister Handling Turntable

remelting of the seal, cooling air is applied to the trough seal through the same tubes that were used to provide steam. The cooling of the seal metal will maintain the seal integrity.

\subsection{REMOTE Y-RAY DETECTOR METHODS}

\subsubsection{Glass Level Detection System}

A glass-level detecting system (Figure 4.2.3) monitors the accumulation of glass in the receiving canisters to preclude the possibility of overfilling. Briefly, the system is designed as follows: eleven gamma activity detectors are positioned within the concrete shielding wall of the B-Cell facility (Figure 4.24). These detectors are oriented and collimated such that the 


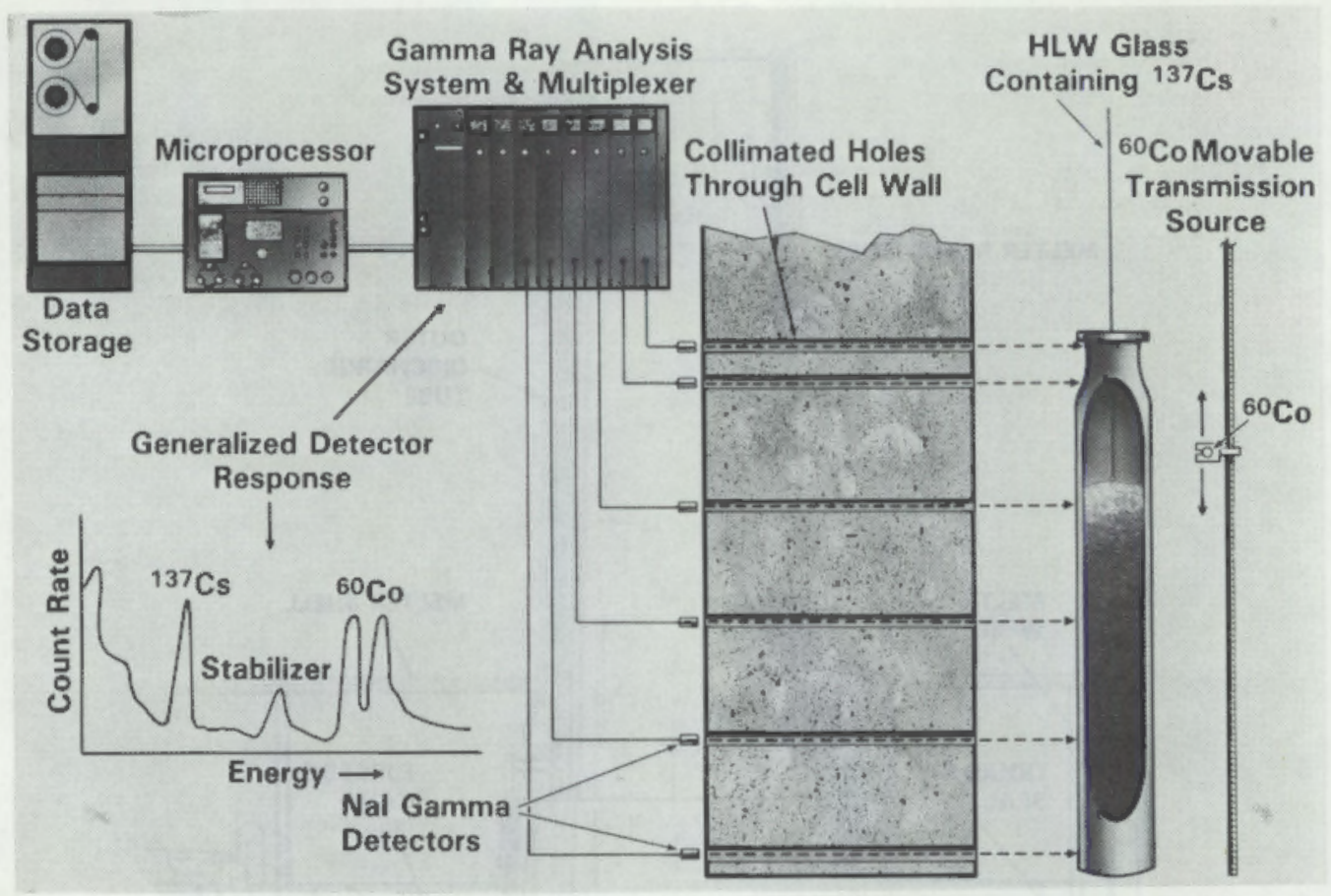

FIGIJRE 4.23. Glass Level Detection System

line-of-sight of each detector views a 5 -cm- (1-in.) dia cylindrical segment of the receiving canister, passing horizontally through the vertical centerline of the canister. A single movable ${ }^{60}$ Co source (3000 curies) (Figure 4.25 ) is positioned on the opposite side of the canister from the gamma detectors sequentially in the line-of-sight of each of the detectors. As glass accumulates at the line-of-sight level of a detector, the ${ }^{60} \mathrm{Co}$ counting rate for that particular detector decreases. The degree of the reduction of the counting rate at any particular detector level indicates the total accumulation of glass at that level. Due to the narrow collimation of the gamma sensor field of view, no indication of the degree of glass accumulation to either side, above or below the detector line-of-sight can be determined. A redundant system utilizing the same eleven gamma detectors monitors the ${ }^{137} \mathrm{Cs}$ gamma activity at each detector level and, since the ${ }^{137} \mathrm{Cs}$ is a radioactive constituent of the glass itself, the ${ }^{137} \mathrm{Cs}$ counting rate for that particular detector will increase as the glass accumulates at the line-of-sight level of a detector. The degree 


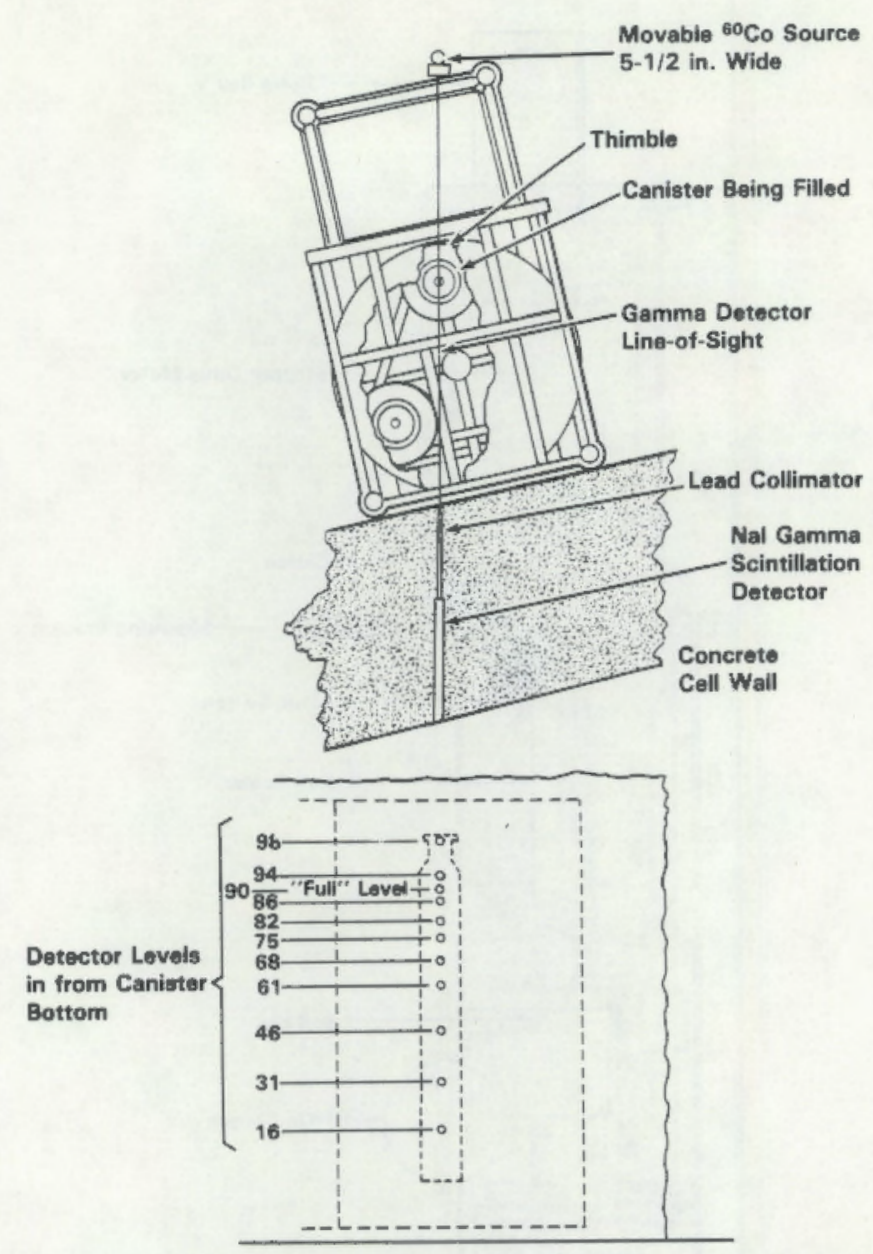

FIGURE 4.24. Gamma Detector Arrangement

of increase of the ${ }^{137} \mathrm{Cs}$ counting rate at any detector level indicates the total accumulation of glass at that level.

Figure 4.24 shows the relative positioning of the ${ }^{60} \mathrm{Co}$ source, the glass receiving canister, and the sodium iodide gamma scintillation detector locations in the cell shielding wall. Figure 4.25 shows how the ${ }^{60}$ Co source holder moves up and down to the level of the various gamma detectors by rotating a ball screw with a reversible stepper motor drive, and how the shaft encoder can maintain an awareness of the location of the source holder regardless of the clutch operation in the event of limit switch failure. Figure 4.26 shows the 


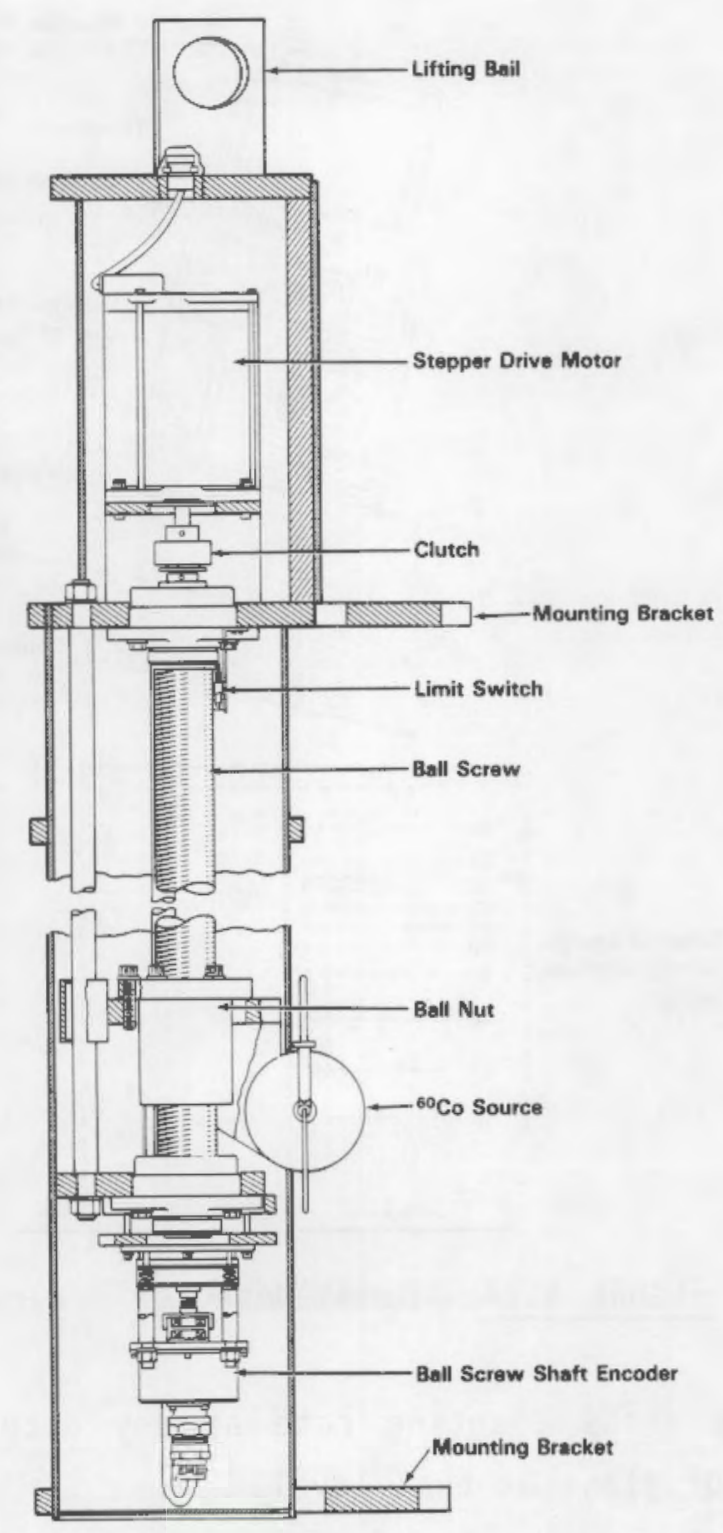

FIGURE 4.25. Cobalt-60 Source Positioner

interrelationship between the in-cell mechanical equipment and the out-of-cell electronic equipment. The microprocessor controls the movement of the gamma source, the operation of the counting instruments, the interpretation of the counting rates, and the display of the results according to predetermined courses of action as selected by operating personnel.

The course of action preprogrammed into the microprocessor is a repetitive cycle where the ${ }^{60} \mathrm{Co}$ source is positioned at the bottom detector level, and the 


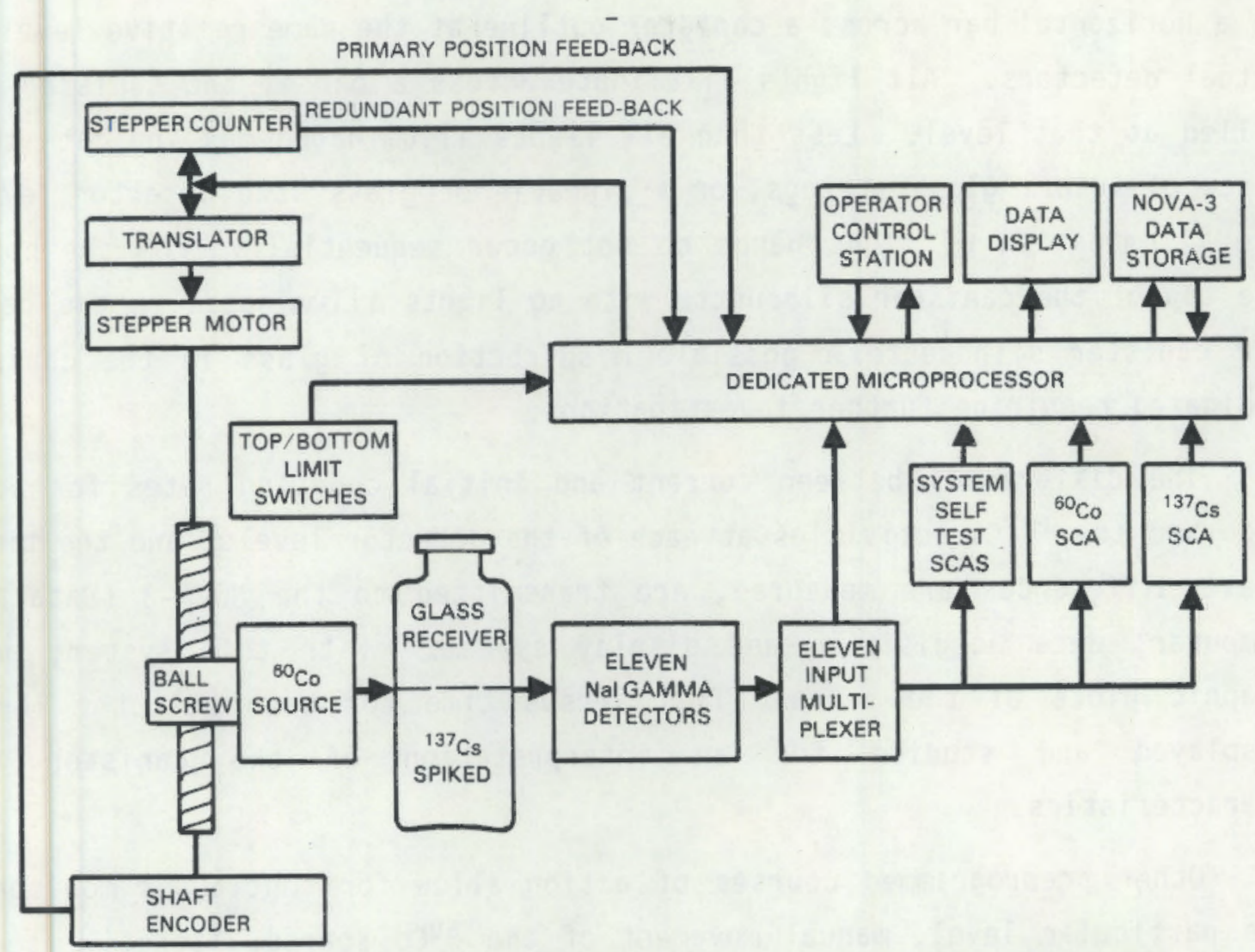

FIGURE 4.26. Glass Level Detection System

${ }^{60} \mathrm{Co}$ and ${ }^{137} \mathrm{Cs}$ counting rates are measured for a predetermined period of time. The source moves up to the next detector level and repeats the cycle until the counting rates have been measured at the topmost detector. At this point, the ${ }^{60} \mathrm{Co}$ source is returned to the bottom detector level and the process can be repeated. This repetitive scanning of the eleven detectors takes a total of about 15 min and continues until another operational mode is chosen by the operating personnel. The ${ }^{60} \mathrm{Co}$ and ${ }^{137} \mathrm{Cs}$ counting rates that are measured at each detector level are compared with similar counting rate measurements that were taken when the canister was initially brought into position under the melter. The difference between the initial and current counting rates indicate glass accumulation in the detector line-of-sight space in the canister. These differences from the initial counting rates are converted into "percent-ofmaximum" glass accumulation values in the microprocessor, and are displayed on a control room panel. The control room panel display uses lights illuminated 
in a horizontal bar across a canister outline at the same relative level as the actual detectors. All lights 111 uminate across a bar if the canister is $100 \%$ filled at that level. Less than all lights illuminated may indicate the presence of voids, glass strings, or a pinnacle of glass at a detector level. If the illumination of light bands do not occur sequentially from the bottom to the top of the canister silhouette with no lights illuminated in the center of the canister silhouette a possible misdirection of glass in the canister is indicated requiring further investigation.

The differences between current and initial counting rates for both the ${ }^{60} \mathrm{Co}$ and the ${ }^{137} \mathrm{Cs}$ activities at each of the detector levels, and the time that these differences are measured, are transmitted to the NovA-3 (Data General computer) data acquisition and display system. With this system, periodic graphic plots of the percent fill versus time for each detector level are displayed and studied for an interpretation of the canister filling characteristics.

Other preprogrammed courses of action allow for continuous monitoring at one particular level, manual movement of the ${ }^{60} \mathrm{Co}$ source, iterative searching for a reference detector location in the event of limit switch failure, and the ability to move the ${ }^{60} \mathrm{Co}$ source from one detector level to another, based on stepper motor pulse counting in the event of failure of the ball screw shaft encoder system.

\subsubsection{Canister Positioning System}

The same dedicated microprocessor used for canister level detection will also be utilized in controlling and verifying proper turntable positioning of canisters under the melter. This will be accomplished by remotely sensing one of three discrete ${ }^{60} \mathrm{Co}$ sources $(8 \mathrm{Ci}, 2 \mathrm{Ci}, 0.5 \mathrm{Ci})$ located within the turntable enclosure. Proper detector exposure to these sources is possible only if the central axis of the canister coincides with the axis of the overflow port within $0.25 \mathrm{in}$. By choosing different curie levels for these turntable sources, the actual canister position as well as its alignment with the melter overflow port is determined. A potentiometer whose resistance varies as a function of turntable rotation will also provide the microprocessor positional 
information should the canister be grossly out of alignment. Internal consistency between the remote $Y$-ray sensor and the potentiometer is always demanded by the nicroprocessor otherwise an off-normal situation is flagged.

\subsection{RIFICATION OFF-GAS TREATMENT SYSTEM}

\subsubsection{Primary Off-Gas Scrubber System}

The off-gas treatment equipment is designed to remove chemical and radiochemical contaminants and particulates from the off gas exiting the RLFCM. The primary components include an ejector venturi scrubber and associated scrubsolution recirculation tank, a packed tower quench scrubber, and a steam jet/condenser. After the initial cleanup, the off gas will pass through several secondary pieces of equipment al ready in place in the hot cells, through a silver zeolite bed and high efficiency particulate air (HEPA) filter and finally to the 324 Building primary off gas scrubber system (see Figures 3.1 and 3.2$)$.

Table 4.3 shows the off-gas conditions from the melter that were assumed for equipment design. Inleakage of air through the flanges on the RLFCM was included, and it was assumed to be the only source of noncondensible gas through the primary off-gas treatment scrub system. The condensible phase will inciude steam, $\mathrm{NO}_{x}$ and traces of chloride and sulfur compounds introduced by the liquid waste. The quantity and composition of the condensible phase will vary depending upon the waste composition and the melter operating conditions. Some particulates will be entrained by the gases leaving the melter. Using an equation for the terminal velocity of a sphere (Bird, Stewart, and Lightfoot 1960), the maximum particle size entrained by the condensible phase arising from the melt surface would be 25 um under normal operating conditions. A 320-um particle would be entrained in the 10.1-cm (4-in.) off-gas line by the condensible phase plus inleakage air. 
TABLE 4.3. Anticipated Off-Gas Conditions Leaving the RLFCM

\begin{tabular}{|c|c|c|}
\hline Variable & Normal Flow & Maximum Flow \\
\hline Flowrate & $45.4 \mathrm{scfm}(104 \mathrm{acfm})$ & $105 \operatorname{scfm}(240 \mathrm{acfm})$ \\
\hline Temperature & $350^{\circ} \mathrm{C}\left(662^{\circ} \mathrm{F}\right)$ & $350^{\circ} \mathrm{C}\left(662^{\circ} \mathrm{F}\right)$ \\
\hline Operating pressure & 10-in. water vacuum & 10-in. water vacuum \\
\hline Particulate rate & $0.3 \mathrm{~kg} / \mathrm{h}$ & $0.3 \mathrm{~kg} / \mathrm{h}$ \\
\hline Particulate size & Submicron to $\sim 30 \mu \mathrm{m}$ & Submicron to $\sim 30 \mu \mathrm{m}$ \\
\hline \multirow[t]{2}{*}{ Particulate type } & $\begin{array}{l}\text { Oxide powders }+ \\
\text { glass fiber }\end{array}$ & $\begin{array}{l}\text { Oxide powders }+ \\
\text { glass fiber }\end{array}$ \\
\hline & Noncondensible Phase & \\
\hline \multirow[t]{2}{*}{ Air } & $55 \mathrm{~kg} / \mathrm{h}$ & $55 \mathrm{~kg} / \mathrm{h}$ \\
\hline & Condensible Phase & \\
\hline Steam & $27 \mathrm{~kg} / \mathrm{h}$ & $109 \mathrm{~kg} / \mathrm{h}$ \\
\hline $\mathrm{NO}_{\mathrm{X}}$ & $1 \mathrm{~kg} / \mathrm{h}$ & $1 \mathrm{~kg} / \mathrm{h}$ \\
\hline Chloride and sulfur compounds & Trace & Trace \\
\hline
\end{tabular}

\subsubsection{Ejector Venturi Scrubber System}

The ejector venturi scrubber system is the first off-gas treatment equipment for the RLFCM off gas. The components include the ejector venturi scrubber and the scrub solution tank (TK-134). Associated with TK-134 are an agitator, a pump, and a seal pot (TK-135).

4.7.1.1.1 Ejector Venturi Scrubber. The ejector venturi scrubber is located on a jumper between the RLFCM and the scrub solution tank (TK-134). It condenses $\sim 95 \%$ of the condensible phase, cools the air, and removes $90 \%$ of the particulate material including all particulates above a mean diameter of 1 micron. At normal flows, the venturi scrubber cools the off gas from 350 to $60^{\circ} \mathrm{C}$. In the process, $\sim 19 \mathrm{~kg} / \mathrm{h}$ of steam is condensed. The remainder of the steam leaves as saturated air at $60^{\circ} \mathrm{C}$. The cooling fluid is condensate at $40^{\circ} \mathrm{C}$, which is recirculated from the scrub solution tank (TK-134). The scrub 
solution is supplied to the scrubber at $114 \mathrm{~L} / \mathrm{min}$ and $80 \mathrm{psig.} \mathrm{At} \mathrm{these} \mathrm{condi-}$ tions, a draft of $7.62-\mathrm{cm} \mathrm{H} \mathrm{H}_{2} \mathrm{O}$ is generated across the venturi scrubber.

The ejector venturi scrubber is a commercially available scrubber modified for this particular application. Corrosion potential dictates the use of Inconel-625 as the material of construction for the entire jumper. A $0.64-\mathrm{cm}$ (1/4-in.) wall thickness was specified for the venturi scrubber itself. The scrub solution connection is made via a PUREX(a) connector with the spray nozzle attached to a female PUREX-type nozzle.

4.7.1.1.2 Scrub Solution Tank (TK-134). The scrub solution tank is located in the $3 \mathrm{~A}$ rack. It contains, cools, and recirculates a water scrub solution to the ejector venturi scrubber.

Because of space limitations, TK-134 was designed with an oval shape and a flat top and bottom $86 \mathrm{~cm}$ (2 ft, $10 \mathrm{in.}) \times 147 \mathrm{~cm}(4 \mathrm{ft}, 10 \mathrm{in.}) \times 183 \mathrm{~cm}$ (6 ft) high. TK-134 has an overall volume of $2000 \mathrm{~L}$ with an active liquid volume of $1700 \mathrm{~L}$. There are $61 \mathrm{~m}(200 \mathrm{ft})$ of 1-in. Sch. 40 Hastelloy C-276 pipe installed in the tank for cooling coils to provide heat transfer area of $6.4 \mathrm{~m}^{2}$ (69 $\mathrm{ft}^{2}$ ). The tank is designed to be replaceable in the cell without replacing the entire 3A rack. Corrosion potentials dictated the use of Inconel-625 as the construction material for the walls and tank supports. Pipe and tubing fabricated from Inconel-625 were not available, so Hastelloy C-276 was used in the construction of the cooling coils and process piping. Inconel-600 was considered as a construction material because it is relatively inexpensive and more available. However, in a laboratory test, a coupon of the material was severely pitted after five days in a solution of $5 \% \mathrm{HNO}_{3}, 1 \% \mathrm{NaCl}$ at $60^{\circ} \mathrm{C}$. Inconel-625 showed no weight loss after a similar treatment.

TK-134 operates at a constant volume of $1700 \mathrm{~L}$. Condensate from the ejector scrubber plus overflow from the quench scrubber (TK-111) leaves TK-134 via a $5 \mathrm{~cm}(2-i n$.$) overflow drain located at the 1.5-\mathrm{m}(5-\mathrm{ft})$ level on the tank. The solution drains to TK-113, first flowing through a U-tube to maintain a vacuum balance between TK-134 and TK-113.

(a) Special remote connector developed at Hanford. 
Scrubber tank instrumentation includes liquid level, specific gravity and pressure dip tubes, and temperature measurement of the off-gas entering the tank and the scrub solution. A conductivity probe is mounted on the tank manipulator face. A steam jet pulls solution past the probe. Other services include chemical addition, an air sparge, jet out to TK-113, and liquid sampling capabilities.

4.7.1.1.3 Agitator. A mechanical agitator provides mixing of the bulk solution in addition to the air sparge ring located near the bottom of the tank. The agitator is a commercially available model with a $183-\mathrm{cm}$ (6-ft) shaft and two 28-cm (11-in.) propellers. The shaft, props, and mounting flange facing are made of Hastelioy $C$. The seal is provided by an integral stuffing box with six carbon packing rings. The agitation provides heat transfer at the cooling coils and uniform suspension of the particulates. The shaft is long enough to maintain agitation while the tank is being drained.

4.7.1.1.4 Pump. A cantilever pump supplies solution to the ejector venturi scrubber. The pump has a 6.375-in. impeller and is driven by a 10-hp motor. All wetted parts are of Hastelloy $C$ and $Y-17$ alloy. At the 80 psi pressure required by the venturi scrubber, the pump provides $40 \mathrm{gpm}$ of solution. The excess volume not used by the scrubber is returned to TK-134.

4.7.1.1.5 Seal Pot $(T K-135)$. The seal pot provides overpressurization protection for the RLFCM and primary off-gas system. The tank is permanently mounted on the $3 A$ rack and is tied into the off-gas system via a jumper to TK-134. The tank is 113-cm (44.5-in.) high $\times 22-\mathrm{cm}(8.625-i n$.) dia and is vented to TK-113. Services include temperature, pressure, weight factor, chemical addition, and jet out to TK-134. All wetted parts are made of Inconel-625 or Hastelloy c-276.

\subsubsection{Quench Scrubber (TK-111)}

The quench scrubber was originally designed to serve as the primary offgas treatment system for a previous test. In the RLFCM system, the quench scrubber provides additional particulate and condensible-phase off-gas scrubbing beyond that achieved with the ejector venturi scrubber. 
The quench scrubber is a 10-in.-dia, Sch, 20, 304L SS vessel packed with 5/8-in., 304L SS pall rings. Two liquid distribution weirs, one near the top of the column and one at the midsection of the column, collect and distribute scrub solution and condensate liquids to the pall ring packing.

A vessel at the bottom of the tower is used to collect scrub solution. Liquid from this vessel feeds a recycle pump. An overflow drain from the collection vessel maintains a constant liquid level. The recycle scrub solution stream is cooled with a water-cooled heat exchanger.

In normal operation, the recycle stream is fed to the lower weir. A cleaner liquid stream such as fractionator distillate is fed to the upper weir to scrub the incoming off gas. Recycle liquid can be fed to the upper and lower weir. Condensate from the steam jet and E-119 condenser is routed to the collection vessel at the bottom of the scrubber to replace solution that has drained from the scrubber.

During operation in the Nuclear Waste Vitrification Program (NWVP) (Hanson and Bjorklund 1980), the quench scrubber had a maximum pressure drop of $10 \mathrm{~cm}$ of water. The flooding point for the packing at gas flow of $55 \mathrm{~kg} / \mathrm{h}$ to $60^{\circ} \mathrm{C}$ was $2.2 \mathrm{~L} / \mathrm{sec}$.

Instrumentation for the quench scrubber includes thermocouples at several levels in the packing, pressure, and weight factor in the tank and on the weirs.

\subsubsection{Steam Jet and Condenser}

The steam jet provides vacuum control for the melter through the primary off-gas treatment equipment. The condenser removes the steam and cools the off gas. The condensate is used to replenish the scrub solution in the quench scrubber TK-111. A venturi flowmeter located after the condenser measures the noncondensible gas flow rate.

The jet/condenser system is located on the $3 \mathrm{C}$ rack. The jet is an existing 1-1/4-in. steam jet. A 1-in. vacuum control valve on a recycle line around the jet controls the vacuum. With the recycle line closed, the jet can pull a vacuum up to $51 \mathrm{~cm}$ of $\mathrm{Hg}$. 
The condenser is a downdraft shell-and-tube design and is constructed of $304 \mathrm{~L}$ SS. An elongated disengaging section at the base of the condenser acts as a seal pot. The condensate drains via an overflow to TK-11l and the off gas exits through the flowmeter to TK-113. The condenser has a heat transfer area of $24.6 \mathrm{ft}^{2}$. During design verification testing of a similar condenser, the overall heat transfer coefficient was calculated to be only $38 \mathrm{Btu} / \mathrm{ft}^{2}-\mathrm{h}{ }^{\circ} \mathrm{F}$. This is based on 4 gal/min cooling water flow at $19^{\circ} \mathrm{C}$ inlet and $43^{\circ} \mathrm{C}$ outlet. Steam entered at $130^{\circ} \mathrm{C}$ and the condensate left at $60^{\circ} \mathrm{C}$.

An off-gas flowmeter is located on a jumper immediately after the E-119 condenser. At normal flows of $55 \mathrm{~kg} / \mathrm{h}$ air, the measured $\Delta P$ at the throat is 10 in. of water.

\subsubsection{Vacuum Control for the RLFCM}

The primary purpose of the off-gas system is to contain and decontaminate gaseous effluents generated during the vitrification of high-level waste. Process equipment, piping connector systems, and high quality piping is used to contain the gaseous effluents. Pressure fluctuations that occur during RLFCM operations require that additional measures be taken to maintain the RLFCM and off-gas system at pressures lower than B-Cell atmosphere. To achieve vacuum control in the RLFCM during operation, two methods are used: 1) oversizing of the primary off-gas scrubber (ejector venturi) to handle three times the normal flow of off gas from the RLFCM, and 2) providing a vacuum boosting system to the primary off-gas system.

The capacity of the ejector venturi was oversized without greatly perturbing the operation of the RLFCM by increasing the total off-gas flow through the RLFCM. This is possible because of the slight draft created by the oversized ejector. Additional off-gas handling capacity is present in the system without substantially reducing the system vacuum.

The vacuum boosting system for the primary off-gas system is comprised of a steam jet and recycle valve located downstream of the quench scrubber. The jet is arranged in a jumper with a control valve that can regulate a recycle stream that goes from the discharge of the jet to the intake of the jet. The control sensor for the control valve is the absolute pressure within the 
RLFCM. At times when more off-gas flow is required, such as during a pressure rise in the RLFCM, the valve on the recycle line of the jet moves towards closure. When less flow is required, the control valve opens, reducing the total off-gas flow through the system.

\subsubsection{Secondary Off-Gas Treatment System}

The vitrification off gas from the off-gas condenser (E-119) is discharged to the secondary off gas system for further treatment. The in-cell equipment components that comprise this system were installed in B-Cell for previous tests. These equipment components include an evaporator (TK-113), an acid fractionator (TK-115), and a primary off gas scrubber (TK-118). These equipment components are briefly described here. A flowsheet presented in Section 3.1 (Figure 3.2) indicates where these equipment components fit in relation to the primary off-gas system. Future inclusion of an jodine adsorber (TK-136) is anticipated.

\subsubsection{Evaporator (TK-113)}

The evaporator has three functions: 1) high-level liquid waste (HLLW) concentration, 2) condensate concentration, and 3) off-gas decontamination. The evaporator is a medium-length, thermosyphon-type evaporator designed to operate with a maximum-to-minimum operating volume ratio of 18:1. The evaporator is constructed from commercially-pure titanium for improved corrosion resistance.

The evaporator tower consists of four stages of deentrainment: 1) a simple chevron baffle at the bottom, 2) and 3) two stages of dry impingement caps in the center, and 4) a remotely replaceable mist eliminator at the top. At the maximum design boilup rate $(500 \mathrm{~L} / \mathrm{h})$, the impingement velocities of stages 1,2 , and 3 are 11,16 , and $26 \mathrm{~m} / \mathrm{sec}(36,51$, and $85 \mathrm{ft} / \mathrm{sec})$, which removes nearly $100 \%$ of aerosols of 25,7 , and $4 \mu \mathrm{m}$, respectively.

\subsubsection{Acid Fractionator (TK-115)}

The all-titanium acid fractionator consists of a packed-tower distillation column surmounting a standard reboil tank. The top and bottom spheroid heads are partially reinforced with an extra thickness of titanium plate for added 
strength, similar to those in the evaporator. Special features of the fractionator include a remotely replaceable tube bundle in the reboiler, a deentraining sieve plate with bypass provisions in the tower, and an integral refiux condenser.

The rectifying section of the fractionator tower is packed with 2.5-cm(1-in.-) dia titanium Raschig rings. The exhausting section includes a similarly packed section surmounted by a deentraining sieve plate and an integral reflux condenser. The fractionator is designed for a liquid feed of up to $0.8 \mathrm{M}$ $\mathrm{HNO}_{3}$, an overhead fraction of $0.01 \mathrm{M} \mathrm{HNO}_{3}$, and a concentrate up to $10 \mathrm{H} \mathrm{HNO}_{3}$.

\subsubsection{Process 0ff-Gas Scrubber (TK-118)}

The scrubber is a 1300-L tank surmounted by a packed scrubbing tower. A recirculating pump recycles the liquid scrub solution to the top of the tower at rates of up to $40 \mathrm{~L} / \mathrm{min}$. Gas flow of up to $11.8 \mathrm{~m}^{3} / \mathrm{min}$ ( $416 \mathrm{scm}$ ) is acceptable. Gas discharged from the scrubber leaves B-Cell and enters the 324 Building vent system.

\subsection{PROCESS CONTROL AND DATA ACOUISITION SYSTEM}

Approximately 170 sensing devices will monitor the operating parameters of the RLFCM facility and its supporting systems. Data from these sensors provide: 1) process variable measurements for feedback for automatic process control systems, 2) process measurements for on-line detailed displays of parameter trends for the prior 72-h period, and 3) a recorded history from which events, circumstances or correlations can be analyzed. Figure 4.27 shows the data acquisition systems.

The microprocessor-based process control system is operated from keyboards located in an operator control console (Figure 4.28) where three color video screens display every aspect of the process controllers and the process operating parameters. All of the conventional analog process requirements for the RLFCM or its auxiliary equipment pieces, such as pressure, temperature, or flow control, are incorporated into the microprocessor system. Operators will be able to simultaneously fine tune one loop on one screen, observe the trend of three selected variables from three separate control systems on another screen, 


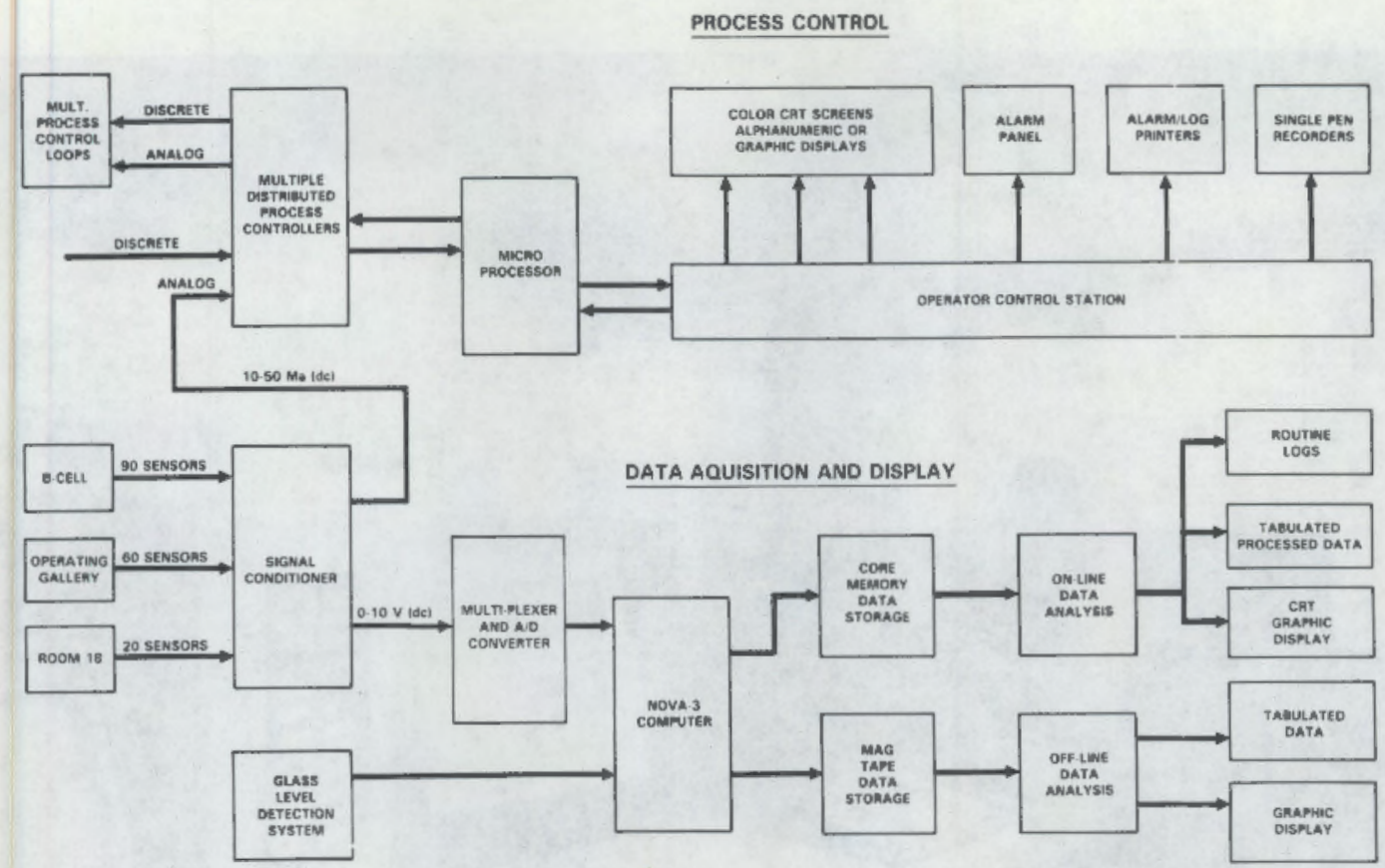

FIGURE 4.27. Process Control and Data Acquisition Systems

and evaluate the overall status of the melter facility on the third screen. Other overview displays, group displays, alarm status displays, and dynamic flowsheet type displays are also available for operator use.

In addition to controlling analog process control loops, "batch"-type control systems are manipulated from the console. An operator can change the pulsing frequency and pattern of the feed tank agitation systems, and the pulsed feed pump delivery rates. Steam jet transfers can be initiated or terminated with the transfer station valve sequencing under microprocessor control.

All of the mixed analog sensor signals, or "variables," are converted to clean, isolated, 0 to $10 \mathrm{~V}(\mathrm{dc})$ analog signals with electronic signal conditioning equipment. Every $5 \mathrm{sec}$ for the 5 -min period before every quarter hour, all of these conditioned variable signals are sampled, converted to digital signals, transferred to the NOVA-3 computer, converted to engineering units, and stored. On the quarter hour, sixty 5-second values for each variable is averaged and the average values stored in separate RAM locations from the 5-sec samples. These 5-min averages are replaced every quarter hour with new average 


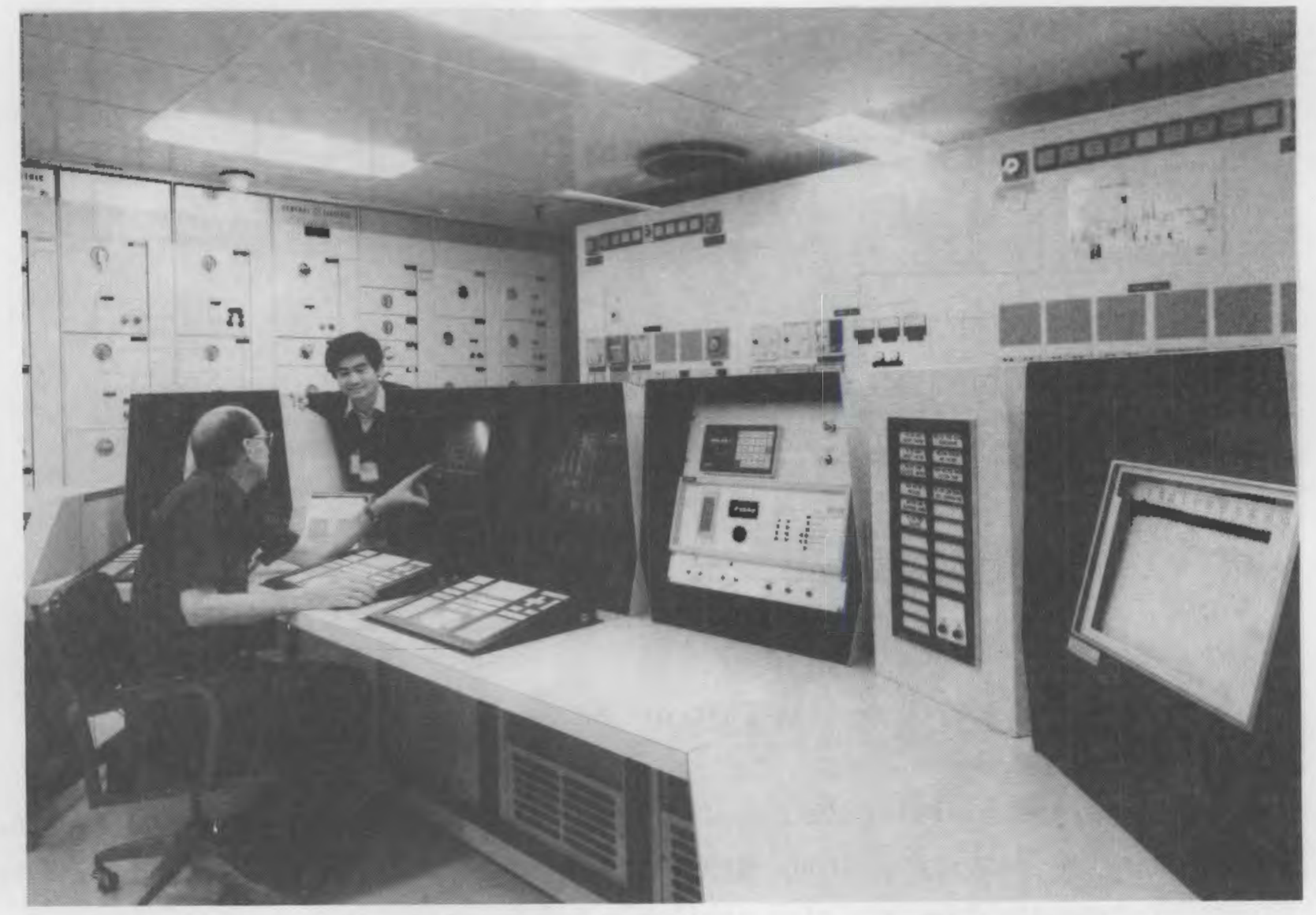

FIGURE 4.28. Console for the Microprocessor-Based Control system

values and are available for calculation logging, or on-line plotting during the 15-min period before being updated with new average values. Psuedo variable values will be calculated from the 5 -min average values immediately after each 5-min average is replaced with a new average value. Pseudo variables are treated exactly like 5-min variable average values and are available for calculation, logging, or on-line trend plotting.

After the 5-min averages have been replaced with new values, each of the current 5 -min average variable values and each pseudo variable value are transferred to magnetic tape for archive storage suitable for off-line retrieval and data analysis. Data on magnetic tape is not available for on-line use.

Every quarter hour, after the 5-min averages have been replaced with new values, a total of 100 selected 5 -min variable values and pseudo variable 
values are transferred to RAM storage that is capable of holding 400 values per variable. These 400 values per variable are available for graphic display versus time either separately or in concert with up to four other variables as trend or correlation displays. Data for the last four days of operation at 15-min intervals are available, with only the initial 60 samples/5-min smoothing.

On-line manipulation of any of the currently held 400 values per 100 variables is permitted for the evaluation of the last four days' data. Data in excess of 400 values per variable is lost to on-line analysis, although it is still available on magnetic tape for off-line analysis after the tape has been filled and the tape file closed. Utilizing the dual tape drive of the NOVA-3 and its background/foreground programming format, off-line analysis of archive tapes is possible, even while the NOVA-3 is performing its primary data acquisition and storage tasks.

\subsection{CANISTERS, CANISTER HANDLING GRAPPLE, AND CANISTER LID WELDING}

The canister design, canister handling grapple, and means for closure of the canister reflect design efforts and criteria developed at PNL over the last several years and reflect the constraints imposed by the equipment systems and shielded cell geometry that comprise the RLFCM system.

\subsubsection{Canister Design}

The turntable can accommodate canisters up to $40.6-\mathrm{cm}$ dia with a length up to $2.64 \mathrm{~m}$. The reference canister for the RLFCM has overall dimensions of 32.3-cm dia $\times 2.64-m$ 1ong. This reference canister, depicted in Figure 4.29, is fabricated from 12-in.-dia, Sch. 40, 304L SS pipe. The bottom of the canister is a $0.375-i n$.-thick reversed dished head. The top flange is fabricated from an 8-in.-dia, 150-1b weld neck blank flange machined to a flatness of 0.002 in. A $12 \times 8-i n$. Sch. 40 s concentric reducer connects the top canister flange with the main body of the canister. This type canister is filled to a glass level of $2.4 \mathrm{~m}$ during operations, containing a total glass mass of $-450 \mathrm{~kg}$. 

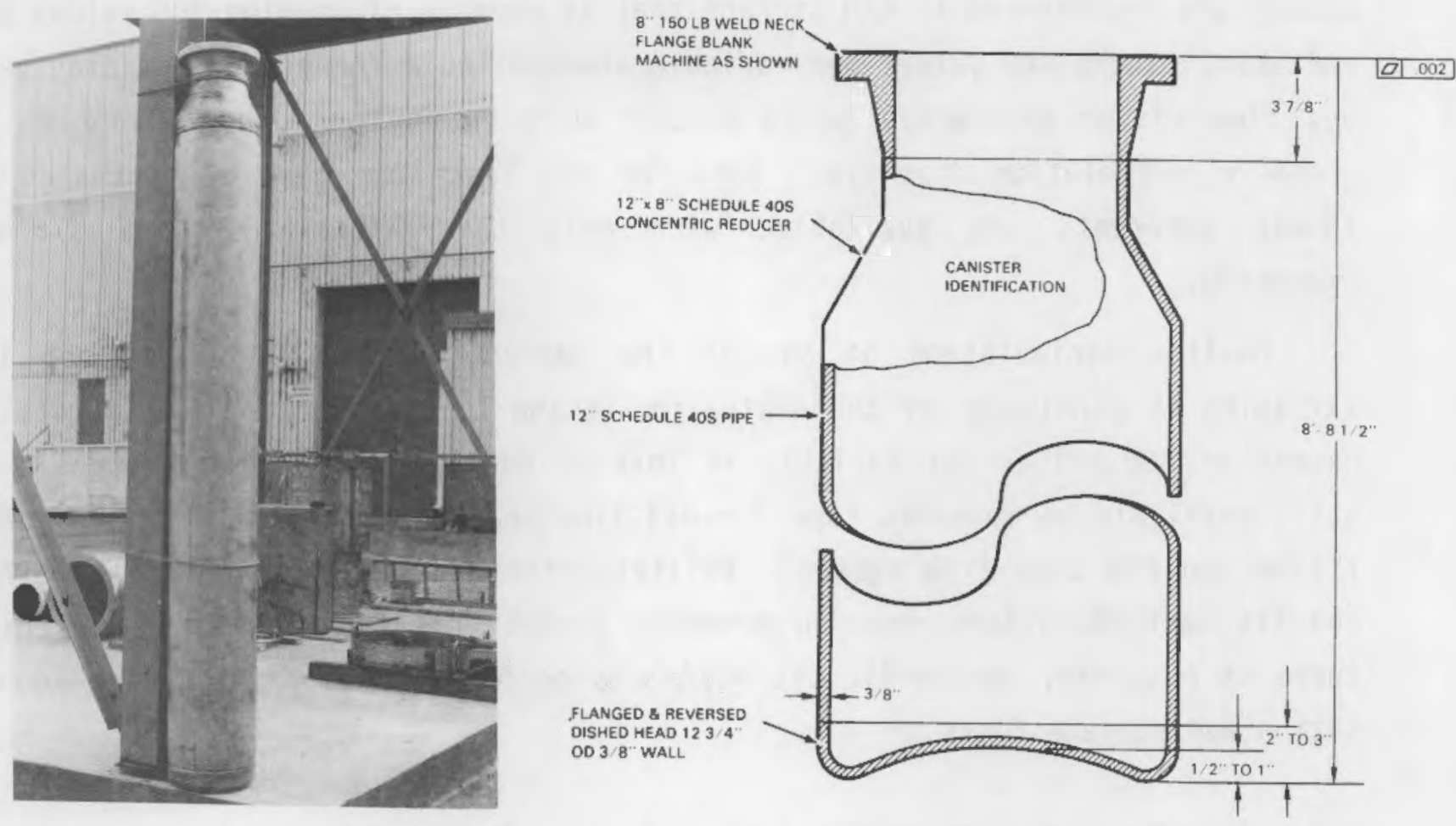

FIGURE 4.29. Reference Canister for the Radioactive LFCM Pilot Plant

The canister lid is fabricated from $304 \mathrm{~L}$ SS plate. The lid is designed for self positioning in the canister. A welder mounted on the canister lid (described in Section 4.9.3) will seal-weld the lid to the canister to complete the containment of the glass.

The canister must provide a high level of containment of the waste glass. Thus, strict fabrication and quality assurance requirements are adhered to during fabrication. To assure a consistent level of high-quality work, the canisters are fabricated in accordance with the American Society of Mechanical Engineers (ASME) Boiler and Pressure Vessel Code, Section VIII, Div. 1, except that no code stamp or hydrostatic test is required.

\subsubsection{Canister Handling Frapple}

The canister handling grapple shown in Figure 4.30 was designed to maximize safety during lifting and transport, minimize stresses to the canister 
during lifting, be operable by the use of an overhead crane only, and be compatible with placement of the reference $30.5-\mathrm{cm}-$ dia canister within a shipping cask.

The grapple was designed to grasp the canister underneath the top flange to provide maximum support during transport. This grapple incorporates a positive-locking system to assure that the canister does not disengage from the grapple during transport. Figure 4.30 shows the open and closed positions for the grapple. Each of these positions is achieved by lifting the appropriate bail on the yrapple. In the closed position, the weight of the canister keeps the four grapple teeth forced in under the canister top lip, essentially locking the canister to the grapple. The grapple is designed so that it will engage only when the canister is properly positioned underneath the grapple. This feature prevents a partial coupling of the canister that could lead to a canister drop.

Disengagement of the grapple from the canister is achieved by lifting the bail that forces the lifting teeth out from under the canister top lip. The total width of the grapple in the disengaged mode is still less than the width
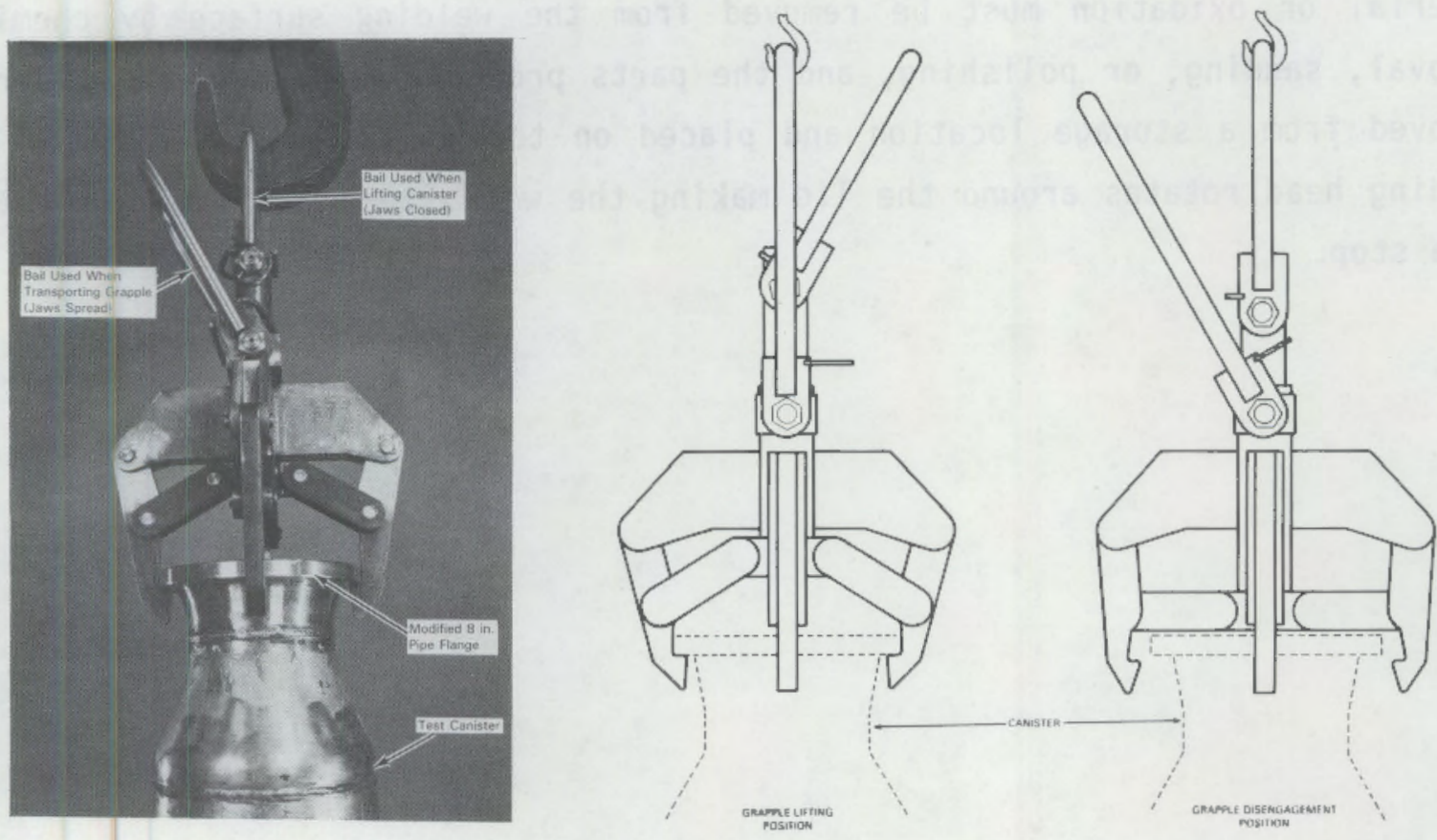

FIGURE 4.30. Cansster Handling frapple Concept 
of the canister, which allows for placement of the canister into shipping casks that have positioning racks only slightly larger in diameter than the canister.

\subsubsection{Canister Lid Welder}

The closure system for the canisters was designed for compatibility between the canister, canister lid, canister sealing requirements, canister lifting requirements, and type of welding technique. A remote welder, depicted in Figure 4.31, uses a GTA-type fusion weld to seal the canister in compliance with hasic design requirements. The GTA process is the most common method in use today for welding nuclear equipment. It has been carefully studied and the techniques for making high-quality welds are well understood. The welder shown makes an autogenous fillet that can range from 3.2- to 6.4-mm (1/8- to 1/4-in.) thick. Tight tolerances are maintained on the lid dimensions to maintain the appropriate gap between the welding tip and the lid. The welder is positioned on a centering device on the lid so that the only fitup requirement is to minimize the gap between the lid and the canister top. The welding device itself is designed for ease of maintenance.

Before the closure is welded, any contaminants such as glass, foreign material or oxidation must be removed from the welding surface by chemical removal, sanding, or polishing, and the parts properly fitted. The welder is removed from a storage location and placed on top of the canister lid. The welding head rotates around the lid making the weld, then automatically slows to a stop. 


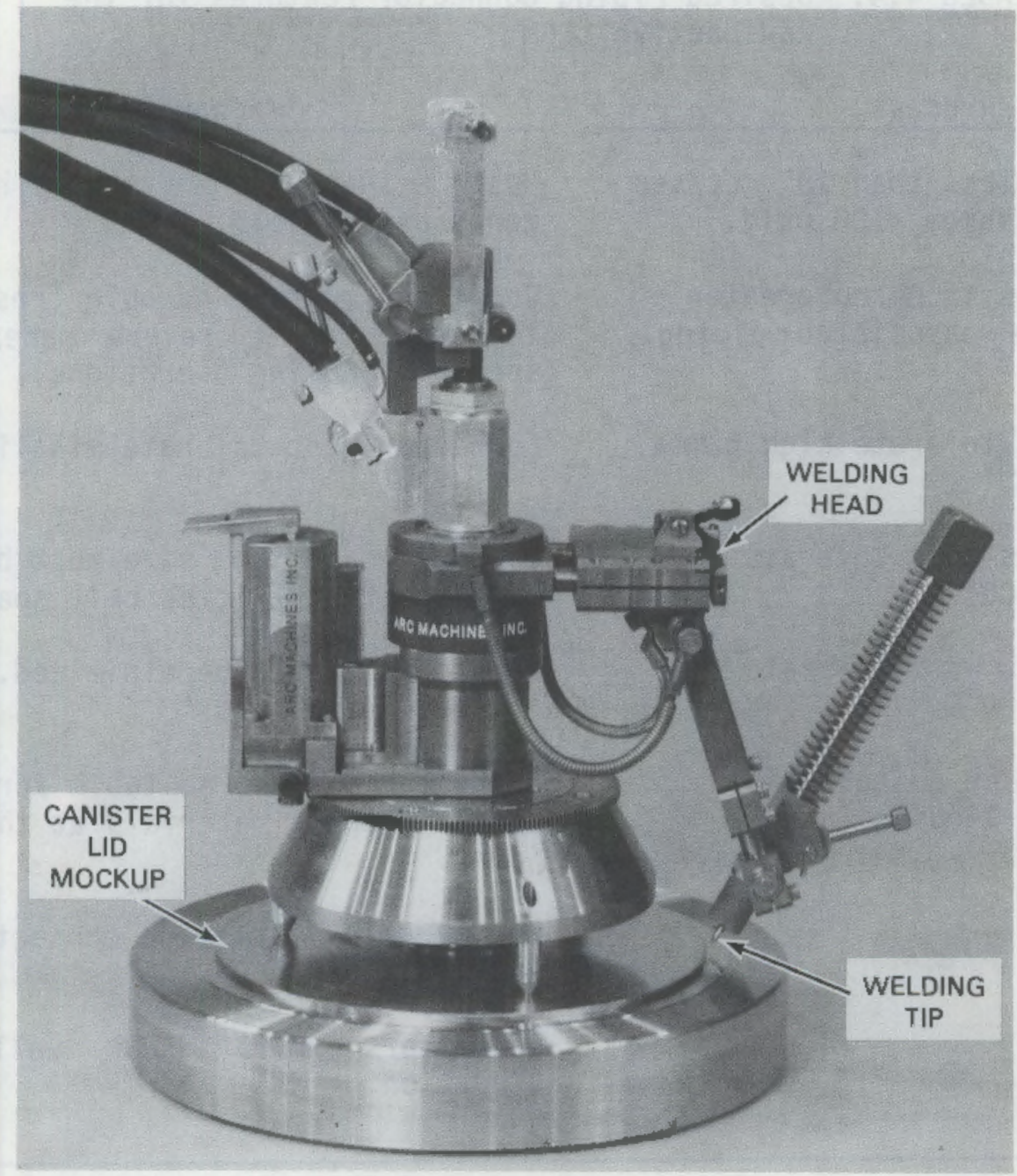

FIGURE 4.31. Concept of GTA Fusion Welder for Canister Closure

\subsection{PIPING CONNECTORS}

Piping connectors were selected to be compatible with the specific chemical process and remote maintenance requirements. Some of these general requirements are summarized in Table 4.4. A key factor in selection of an appropriate connector is the type of handling zone where the connector is to be based. Two different handling zones can be identified within B-Cell:

- In fully-remote handling zones, all maintenance operations are performed using the remote overhead crane and an impact wrench suspended from the crane hook. Viewing is accomplished either 
TABLE 4.4. Desired Piping Connector Features for the Radioactive LFCM

\section{Process}

Leakage to be less than $10^{-3} \mathrm{cc} / \mathrm{sec}$ helium at pressures $<100$ psig.

Corrosion rates to be no greater than with the associated piping.

Connector must tolerate high gamma, beta radiation.

Most connectors must tolerate temperatures to $200^{\circ} \mathrm{C}$.

Some connectors must tolerate temperatures to $700^{\circ} \mathrm{C}$.

Connector must be suitable for sealing gases, liquids, and slurries
Mechanical

Must be adaptable to as many handling zones as possible.

Connector must be durable (resistant to damage under severe make/break or special handling operations).

Connector must tolerate misalignment.

Connector and tool size must be minimum to fit restricted cell space.

Maintenance must be minimized.

Connector must be suitable for connecting different materials at the same joint.

Size from 1/4-in. pipe connector to 14in. tank nozzle.

Connectors must hold well during vibration.

through shielding windows or with closed-circuit television. These areas are out of manipulator reach and are usually inside, on top of, or on the aisle of racks inaccessible from the viewing windows.

- In the semiremote handling zones, maintenance operations are' performed with at least one master-slave manipulator and usually an overhead crane. These maintenance zones are located around the viewing windows.

Six types of connectors are used in the equipment systems for the RLFCM pilot plant:

- Block connectors

- Hanford remote connectors, called PUREX connectors 
- Hanford remote large flanges

- Modified pipe flanges

- Compression-type tubing fittings

- Quick-disconnect fittings with and without integral shutoff.

A brief description of the first four piping connector types is given below.

\subsubsection{Block Connectors}

The block connector, shown in Figure 4.32, was developed by PNL specifically for use in the equipment systems located in B-Cell, and is the most commonly used pipe connector in B-Cell. The block connector offers mechanical simplicity, durability, ease of operation with manipulators, a small size for respective pipe sizes, and the option for using various types of face seals.

The block connector consists of male and female pipe nozzles on the ends of metal blocks, a U-shaped box-like hooking clamp with nonmoving side arms, a clamping bolt, and a gasket. One or two dowels are normally used in the male nozzle for guide-in. The female nozzle is normally welded to the fixed equipment (e.g., at the end of a pipe that is welded to a major process vessel and terminates at the rack face), while the male nozzle and the clamp are on the pipe jumper. The female connectors on the process racks are mounted to permit $1 / 16$ to $1 / 8 \mathrm{in}$. of movement in any direction to allow for misfits in the piping jumpers.

Two versions of the block connector are used: the swing-type, and the backaway-type (Figure 4.32). In the swing-type connector, the male block is attached to the clamp by roll pins that act as pivot points for rotating the clamp about the male block. The two parallel-faced nozzles on each end of the removable jumpers are first oriented directly in front of their respective mating nozzles with the clamps swung out of position. The mating nozzles are pushed together after being lined up, using the alignment dowels. After the nozzles are together, the clamps are swung into position behind the female blocks, and the clamps are tightened by turning the bolts with a wrench. The swing connector is frequently used on rigid pipe jumpers. In the backaway type 


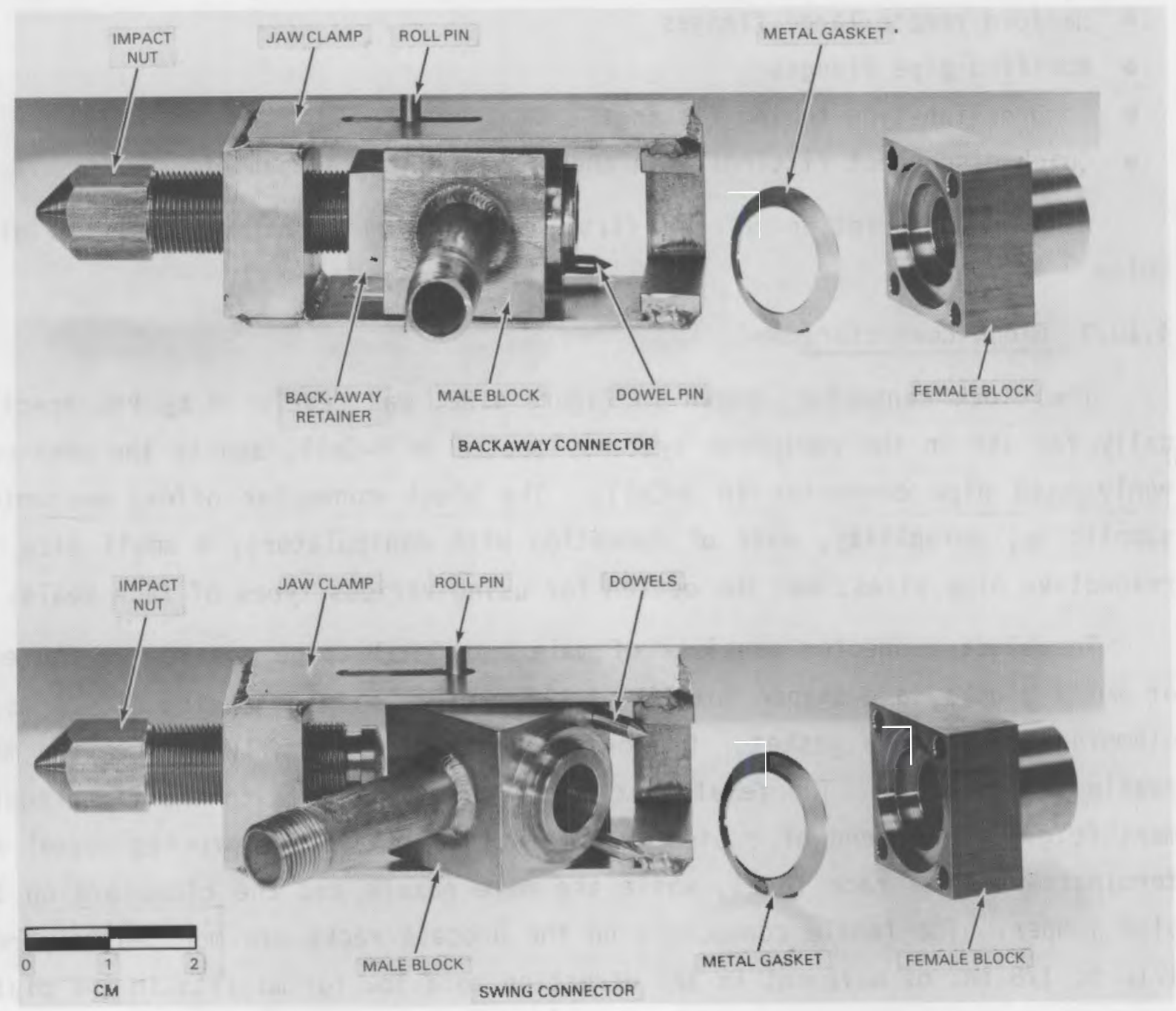

FIGURE 4.32. Block Connectors

connector, the male block is attached to the clamp by roll pins plus a loosefitting joint at the end of the bolt. For connections, the two mating nozzles are brought into approximate alignment by sliding the pipe jumper into position with the clamp behind the female block, then pushing the two nozzles together as guided by the dowels. The bolt is then tightened to seal the joint. For disconnection, the two blocks are pulled apart directly as the bolt is loosened. The backaway connector is frequently used on flexible pipe jumpers where the positive separating action is especially beneficial. 
Connector dimensions and space requirements for the three sizes of block connectors used in B-Cell are listed in Table 4.5. These space requirements may be compared with the 6-in.-dia clearance circle required for the 1-in. 150-1b standard pipe flange.

TABLE 4.5. Overall Dimensions of Block Connectors Used in the RLFCM System

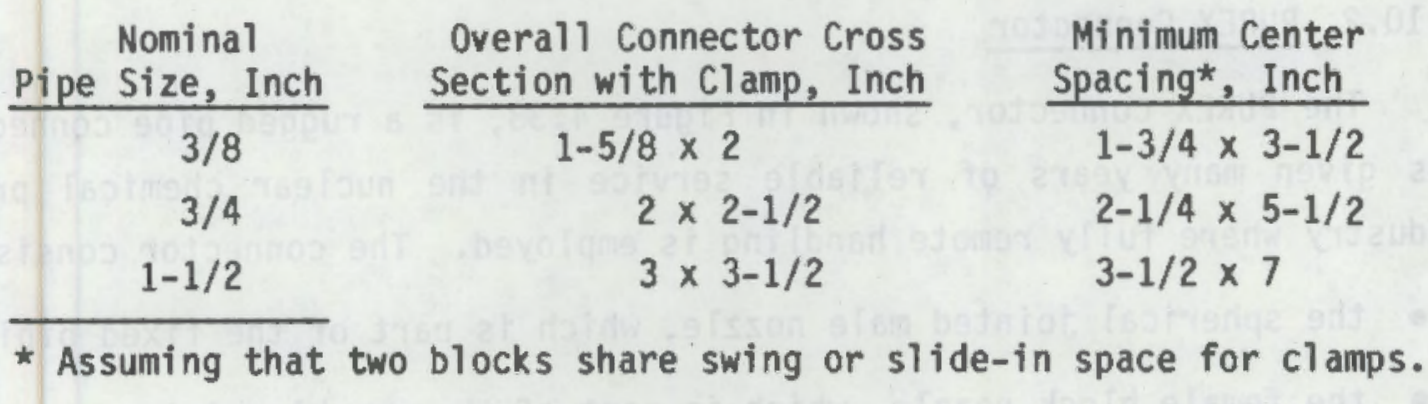

The face seal selected for the block connector is a patented configuration known as the conoseal. The Conoseal features conical nozzle surfaces between which the metal conical gasket (a Belleville washer) is slightly flattened to produce a toggle action on the gasket. This flattening generates high unit seal pressures with minimum clamping forces. This type seal was chosen as basic to the block connector for four major reasons:

- Nozzles can be fabricated from austenitic stainless steel, titanium, or other materials available as bar stock that are machinable and weldable. Hence, they are readily adaptable to most B-Cell piping systems and for use in transition joints le.g., stainless steel or Inconel to titanium).

- The seal is reliable and meets the leakage criteria in Table 4.4 under the adverse conditions of remote handling.

- The all-metal nozzle is resistant to corrosion, radiation, and high temperatures; hence, it has a wide range in B-Cell processes.

- Sealing surfaces are protected by internal geometry against damage in remote handling, resulting in a relatively durable seal that suffers very little from the rough handling associated with remote operations. 
The seal is also usable with soft gasketing materials, such as Teflon, Neoprene ${ }^{\circledR}$, or asbestos. Long-term effective sealing is accomplished with those materials that are normally damaged by radiation because they are held in place within the joint.

Some of the 1-1/2-in. connectors have three small pipes (one 1/2-in. and two 1/4-in.) arranged in a triangle. These are used for liquid samplers.

\subsubsection{PUREX Connector}

The PUREX connector, shown in Figure 4.33 , is a rugged pipe connector that has given many years of reliable service in the nuclear chernical processing industry where fully remote handling is employed. The connector consists of:

- the spherical jointed male nozzle, which is part of the fixed piping

- the female block nozzle, which is part of the movable piping

- the guide skirt and Teflon or Teflon-asbestos gasket subassembly

- the three-jar gear-puller type clamp mechanism with a 2-in. drive nut.

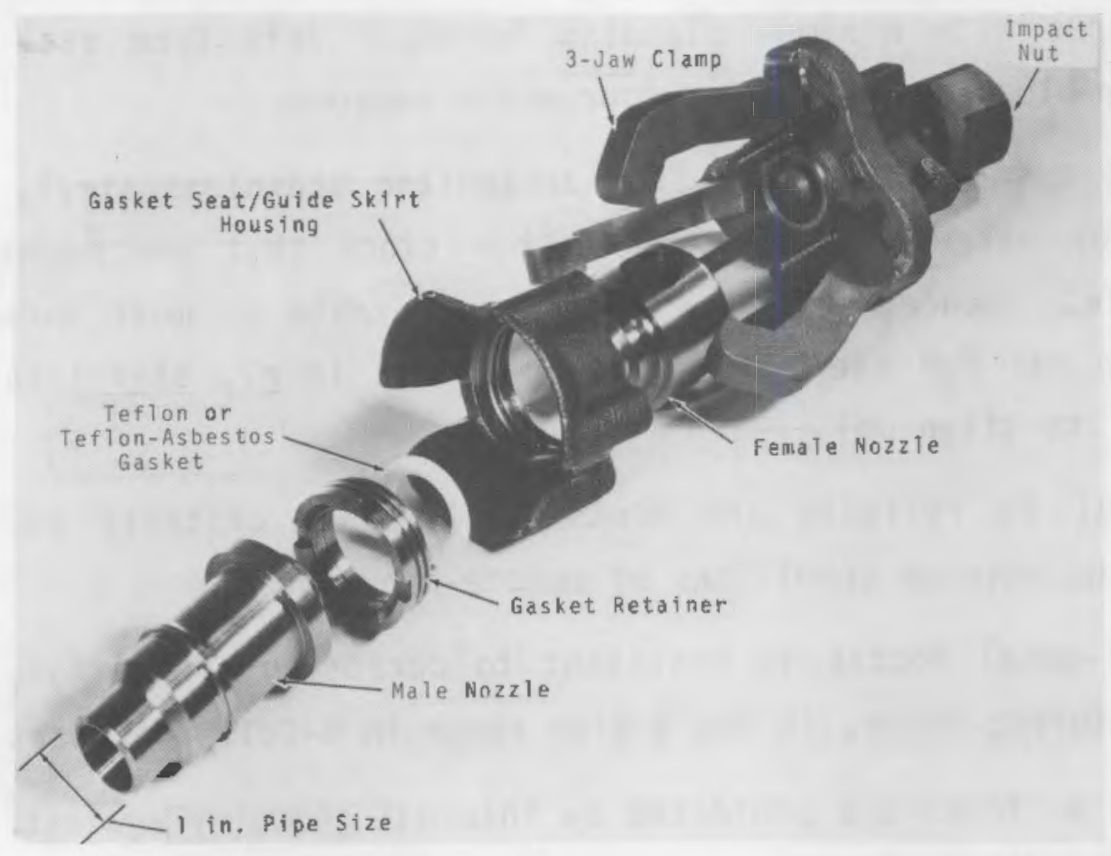

FIGURE 4.33. PUREX Connector 
The female block, guide skirt, and clamp are bolted together as a unit on a jumper before they are put into the shielded cell. The pipe jumper, which is hanging from its balance point on a crane hook, is placed on the fixed male connector with the clamp hooks open. The loose jumper is held in position by its own weight, by the guide skirt, and by the stabilizing action of the open clamp hooks. An impact wrench is then picked up with the crane, piaced on the clamp drive nut, and operated remotely to close the clamp and seal the connector nozzles. Positioning is normally accomplished remotely by viewing through a periscope, closed-circuit camera, or shielding windows. Connectors are designed to be operated by impact wrenches rated for $500 \mathrm{ft}-1 \mathrm{~b}$ of torque. The connector provides a good seal long after the gasket deteriorates due to radiation, because the gasket is wholly confined until the connector is loosened.

\subsubsection{Hanford Remote Flange}

The Hanford remote flange was developed for remote operation in applications where the PUREX three-jaw connector could not be used, primarily for joining pipes larger than 4-in. in diameter. These flanges are used for mounting pumps, agitators, and tube bundles on nozzles that are 25.4 to $40.6 \mathrm{~cm}$ (10 to 16 in.) in diameter. Flat face sealing is employed with stainless steel/blue asbestos spiral-wound gaskets.

Remote flanges are machined from plate that is $1.9-$ to $3.2-\mathrm{cm}-$ (3/4- to 1-1/4-in.) thick. The flanges are guided into place by two diametrically opposed dowels, and are fastened by four remote studs. The remote studs have Acme threads and tapered thread lead-in for ease of thread engagement with the nuts. Nuts are standardized at $5.08 \mathrm{~cm}$ (2 in.) across the flat portion of their hexagonal shape. The nuts have a tapered head for ease of engagement of the socket of the impact wrench and threadless lead-in at the bottom of the nuts. Retaining cups on the flanges hold the nuts in position during equipment transfer and removal. Remote dowels on the mating fixed flanges are tapered on the end and are of unequal length for improved ease of engagement. 


\subsubsection{Modified Pipe Flange}

Standard two-three-bolt pipe flanges are used in the cell only where the equipment is not readily adaptable to other types of connectors. These types of connectors are used on top of the melter main cavity and discharge 1 ids. Flanges are not commonly used in the cell because multibolt flanges are timeconsuming to make and break (particularly when engaging stainless steel bolts and nuts). Small parts are also troublesome to handle. Where flanges are required, they are modified for in-cell use by tapping or welding nuts to the flanges to eliminate loose nuts, and by splitting "permanent" flange and bolting it around the stub end of the pipe. If the threads on the flange gall, the flange may be removed and replaced.

\subsection{SAMPLING}

For process control and characterization, liquids, molten glass, solids, and gases will be sampled at various locations in the process.

\subsubsection{Liquid Sampling}

Liquid sampling capability is provided at all process equipment tankage and several process condensate streams. The liquid sampler shown in Figure 4.34 uses an air ejector to pull the full flow of the sample through the sample bottle before returning the sample flow to the tank.

The liquid sampler is a removable device that is connected to the manipulator rack face in the cell with a three-way block connector. The sampler contains all the equipment necessary to draw samples, except the connecting lines to the tank. The sampler consists of a toggle linkage mechanism for positioning the sample bottle, a sample transfer jet, manual valves for the jet motive gas, and the jet suction pipe, and interconnecting piping. Fifteen milliliter glass sample bottles are placed in the positioner cup, and the positioner is raised to seal the bottle against a gasket surrounding the two sampler tubes. The air supply to the jet is turned on and the sample suction valve is opened. Liquid is drawn out of the tank and through the bottle, returning to the tank. After sufficient circulation to ensure a representative sample ( $5 \mathrm{~min})$, the two sampler valves are closed and the filled sample bottle 


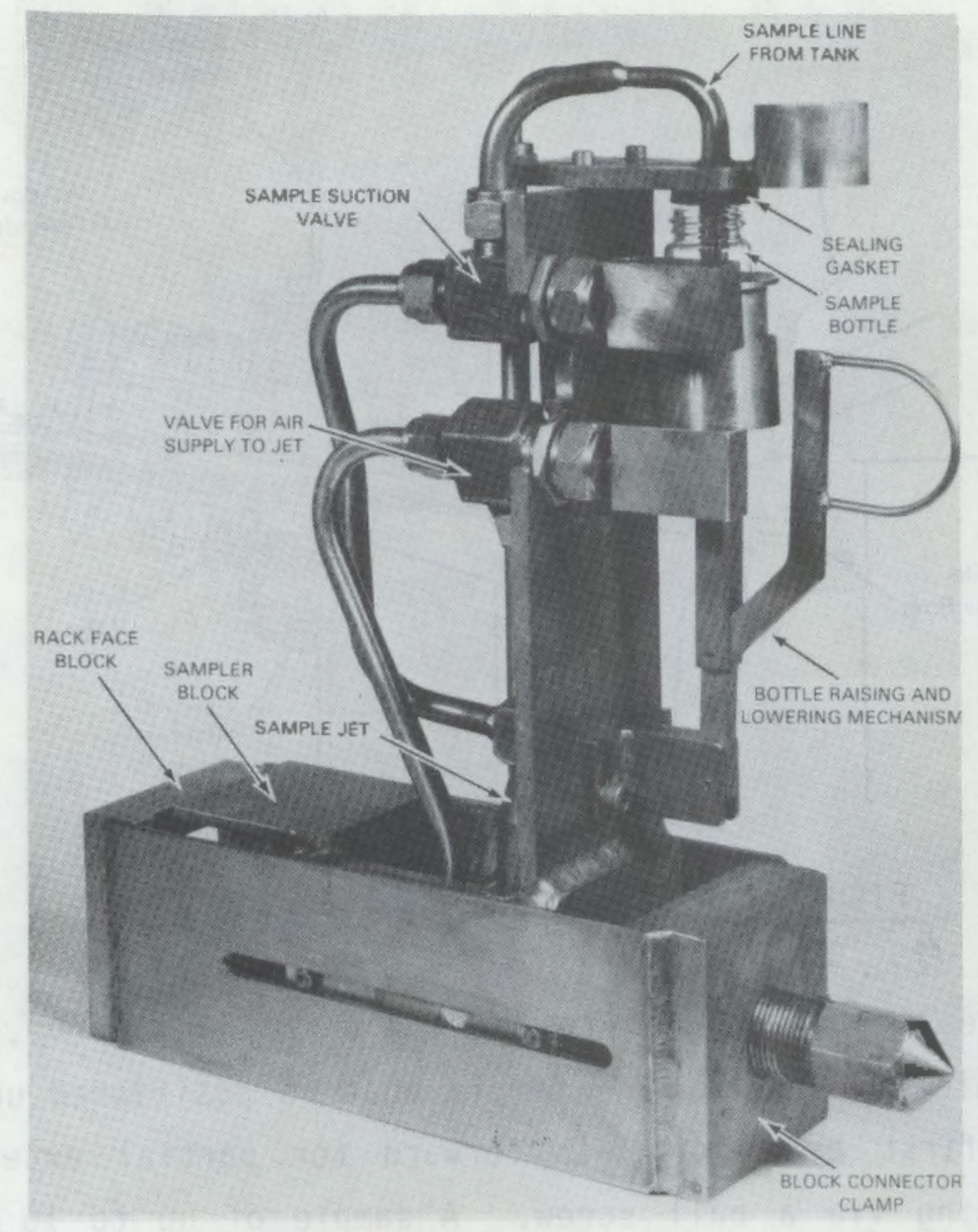

\section{FIGURE 4.34. Liquid Waste Sampler Assembly}

is removed and capped with a screw-top lid. The sample is placed in an appropriate shielded container, and removed from the cell for analysis.

The liquid waste sampler will circulate $0.4 \mathrm{~L} / \mathrm{min}$ of liquid using $15 \mathrm{~L} / \mathrm{min}$ of motive air at $90 \mathrm{psig}$ for a $3.96-\mathrm{m} \mathrm{lift.} \mathrm{If} \mathrm{steam} \mathrm{is} \mathrm{used,} \mathrm{the}$ liquid flow rate through the sampler will be $4 \mathrm{~L} / \mathrm{min}$. The liquid holdup in the suction piping will be $1 / 2$ to $1 \mathrm{~L}$.

\subsubsection{Molten Glass Sampling}

Molten glass is sampled as it falls from the melter pouring tip into the receiving canister. The liquid glass sampler (Figure 4.35) is mounted on the viewing port of the melter discharge section. The sampler consists of a 


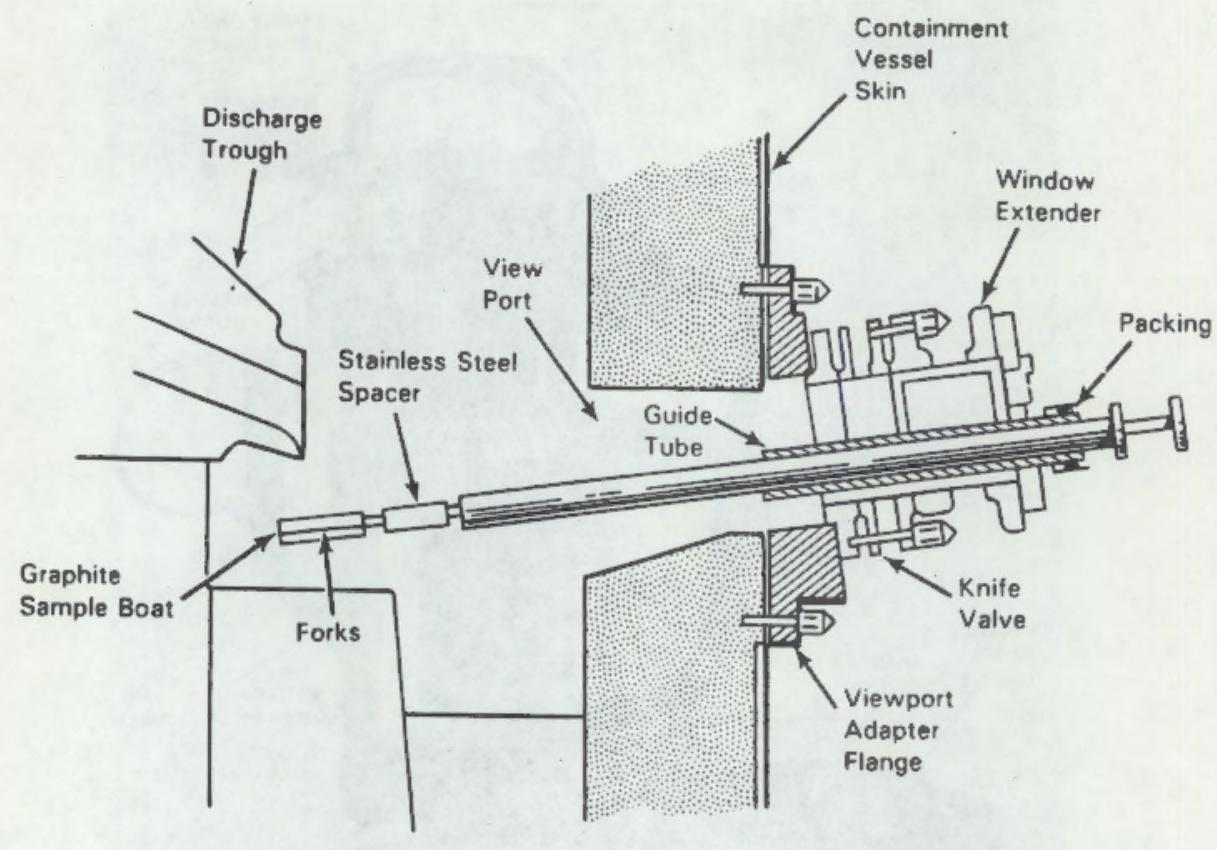

FIGURE 4.35. Molten Glass Sampler Assembly

graphite sample "boat" attached to the end of a sliding rod, which is fabricated from stainless steel. The sample boat is positioned under the pouring glass stream first by sliding it forward for partial extension, and then further extending via a ball screw. A sample of up to $10 \mathrm{~mL}$ in volume is taken from the pouring stream. Two wire fingers extending over the boat allow the sample to remain in place as the sample is withdrawn from its sampling positioning, first by retracting the ball screw, then by manual retraction by a master-slave manipulator. Once fully retracted, a slide valve will cover the discharge section viewport, the sample flange will open, swing aside, and the glass sample, now solidified, will be displaced from the sample cup into a sample container.

This means of sampling allows essentially continuous sampling of the glass discharged from the melter. The information received from these catch samples represents the glass quality inside the canister. This nondestructive means of glass sampling is preferred over core drilling of the canister, which degrades the quality of the waste glass canister by creating voids and cracks in the glass monolith. 


\subsubsection{Off-Gas System Sampling}

The RLFCM off-gas sampling network has been designed specifically to characterize the pathways and magnitudes of melter feed component losses, to establish the performance of RLFCM off-gas system processing equipment, to monitor potentially hazardous off-gas system conditions, and to provide real time information regarding processing status and stability. To accomplish this, an on-line gas mass spectrometer will be used for noncondensible process exhaust gas analysis and in-cell effluent samplers for off-gas emission and performance studies. Each of these sampling subsystems are described below.

\subsubsection{RLFCM Gas Analysis}

The composition of process noncondensable gas will be established using a gas mass spectrometer. The mass spectrometer and its associated control instrumentation is rack mountable as shown in Figure 4.36. This instrument will monitor process conditions by quantifying the emission rates of noncondensable gases $\left(20^{\circ} \mathrm{C}\right)$ generated by the RLFCM. The concentration of these gases will be used to assess processing rates, their temporal behavior will be used as a measure of process stability and the oxides of carbon and nitrogen, if present, will provide information on the REDOX conditions of the melter feed and product glass. Tracer gases, injected into the process, will quantify flow rate and assess process variables as diverse as off-gas flammability and melter freeboard. This instrument can provide diagnostic and processrelated information, and this potential will be developed for maximum use in the RLFCM system.

The sample gas presented to the mass spectrometer is in the form of a flowing, nonpressurized bypass stream, which must be both clean and dry. A gas processing system has been designed to achieve these conditions while minimizing undesirable affects upon gas composition. This system is composed of gross and polishing demisters, a filter, a permeation dryer, and two absolute filters in series. Of these components only the permeation dryer and the absolute filters will be located out of the hot cell. These out-of-cell 


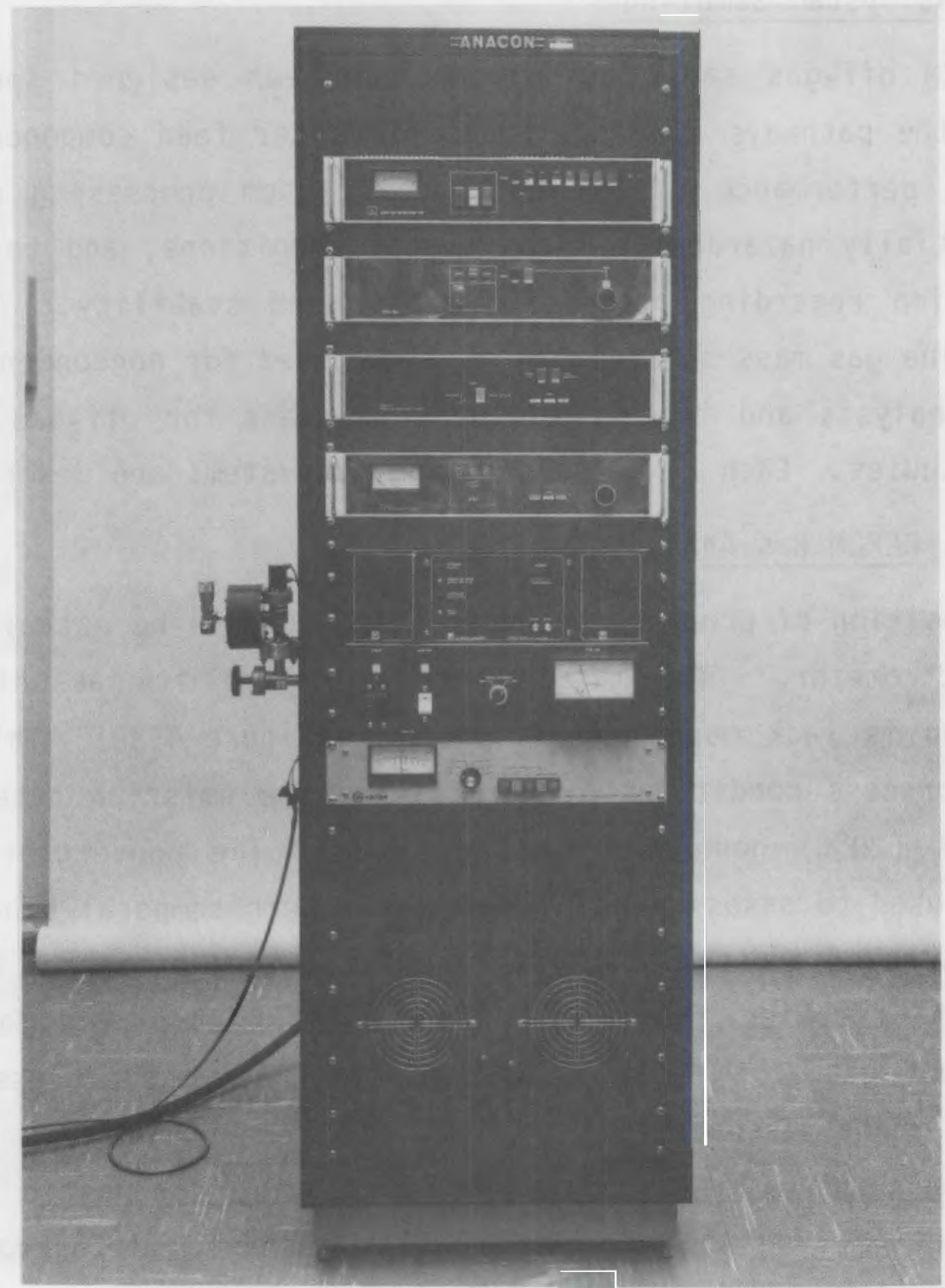

FIfIIRE 4.36. Mass Spectrometer and Associated Control Instrumentation

components will be housed in the B-Cell sample room hood, although no significant contamination of the components is anticipated. The entire gas processing system is completely passive and requires little more than compressed air service.

Specific engineering design details illustrating the location and interconnection of system components appear in Figure 4.37. The process off-gas (POG) sampling point is an experimental variable that can be chosen to suit RLFCM run objectives. However, only quenched process off-gases can be sampled 
$\stackrel{+}{\infty}$

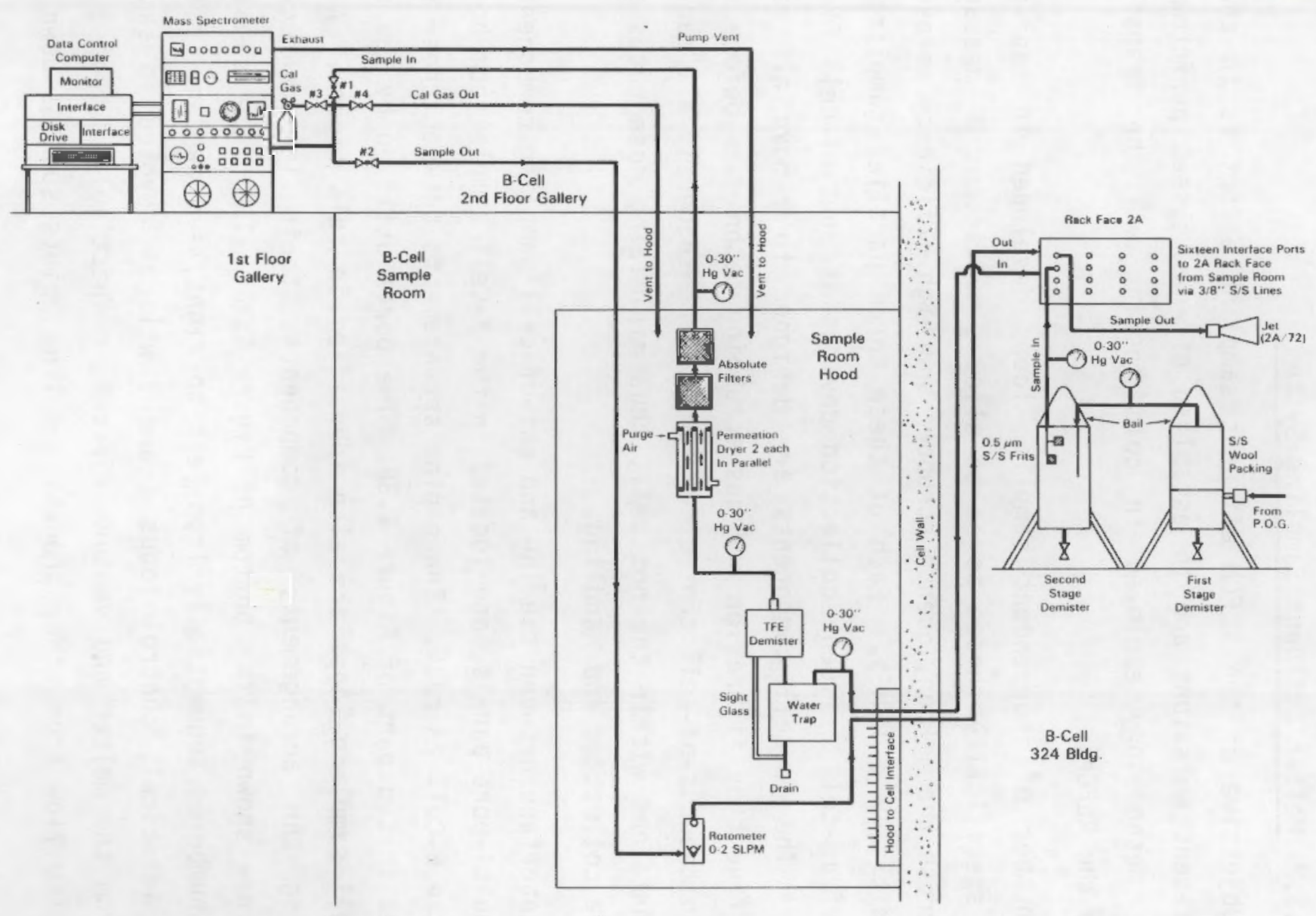

FIGURE 4.37. RLFCM Noncondensable Gas Analyses System Components 
without employing additional in-cell gas treatment equipment. The sampling point and sample processing/analysis system will be interconnected using flexible polyethylene $1 / 4^{\prime \prime}$ tubing. The routing of this 1 ine will be variable as will be the sampling site.

\subsubsection{Melter Effluent Sampling System}

The objective of the RLFCM effluent sampling effort is to characterize melter effluent emissions and to establish off-gas system performance. All analytical methodology employed in cold testing will be transferred and applied to the RLFCM.

The number of independent sampling loops developed in support of the RLFCM was specifically chosen so as to allow simultaneous DF measurements to be made across the melter, quench scrubber and high efficiency aerosol removal device (initially a HEME). Each of these three parallel sampling loops is composed of in-cell effluent collection devices and out-of-cell flow control equipment. The in-cell components are designed to remove all radioactive process effluent by filtration and gas scrubbing techniques before the gas is conveyed to the out-of-cell control equipment. Consequently all radioactivity will be contained within the hot cell, thus minimizing dose rates associated with sample collection and handling.

The interface between the in- and out-of-cell sampling components is provided by multi-port panels, one located in the B-Cell sample room hood and the other in the $\mathrm{B}-\mathrm{Cell} 2 \mathrm{~A}$ rack. The piping arrangements between these two panels is detailed in top part of Figure 4.38. The ports utilized by the three parallel B-Cell sampling loops are also identified in this figure. A schematic illustrating the arrangements of components, their interconnections and locations are shown in the bottom of Figure 4.38 . The three sample control loops are numbered sequentially from left to right as shown and, although all loops are identical, control loops 1 and 2 will be devoted to sampling the exhaust from the melter and venturi ejector, respectively. Loop 3 will control sampling flow from other process sampling points such as down stream of the HEME. 
Sample Hood Pane

\begin{tabular}{|cccc|}
\hline 16 & 12 & 8 & 4 \\
15 & 11 & 7 & 3 \\
14 & 10 & 6 & 2 \\
13 & 9 & 5 & 1 \\
\hline
\end{tabular}

B-Cell Panel

\begin{tabular}{rrrr|}
\hline 1 & 2 & 3 & 4 \\
5 & 6 & 7 & 8 \\
9 & 10 & 11 & 12 \\
13 & 14 & 15 & 16
\end{tabular}

Line Utilization for B-Cell Sampling

\begin{tabular}{c} 
Line $*$ \\
\hline 4 \\
2 \\
12 \\
11 \\
14 \\
3 \\
15 \\
16
\end{tabular}

Description"

POG Sample Stream Supply to Pump *1

POG Sample Stream Exhaust from Pump *1

POG Sample Stream Supply to Pump \#2

POG Sample Stream Exhoust from Pump $\# 2$

POG Sample Siream Supply to Pump 13

POG Sample Stream Exhaust from Pump \#3

POG Sample Stresm Supply to Mass Spectrometer

POG Sample Stream Exhaust from Mass Spectrometer

-Pumps are numbered from lelt to right and clearly Iabeled in sample room hood

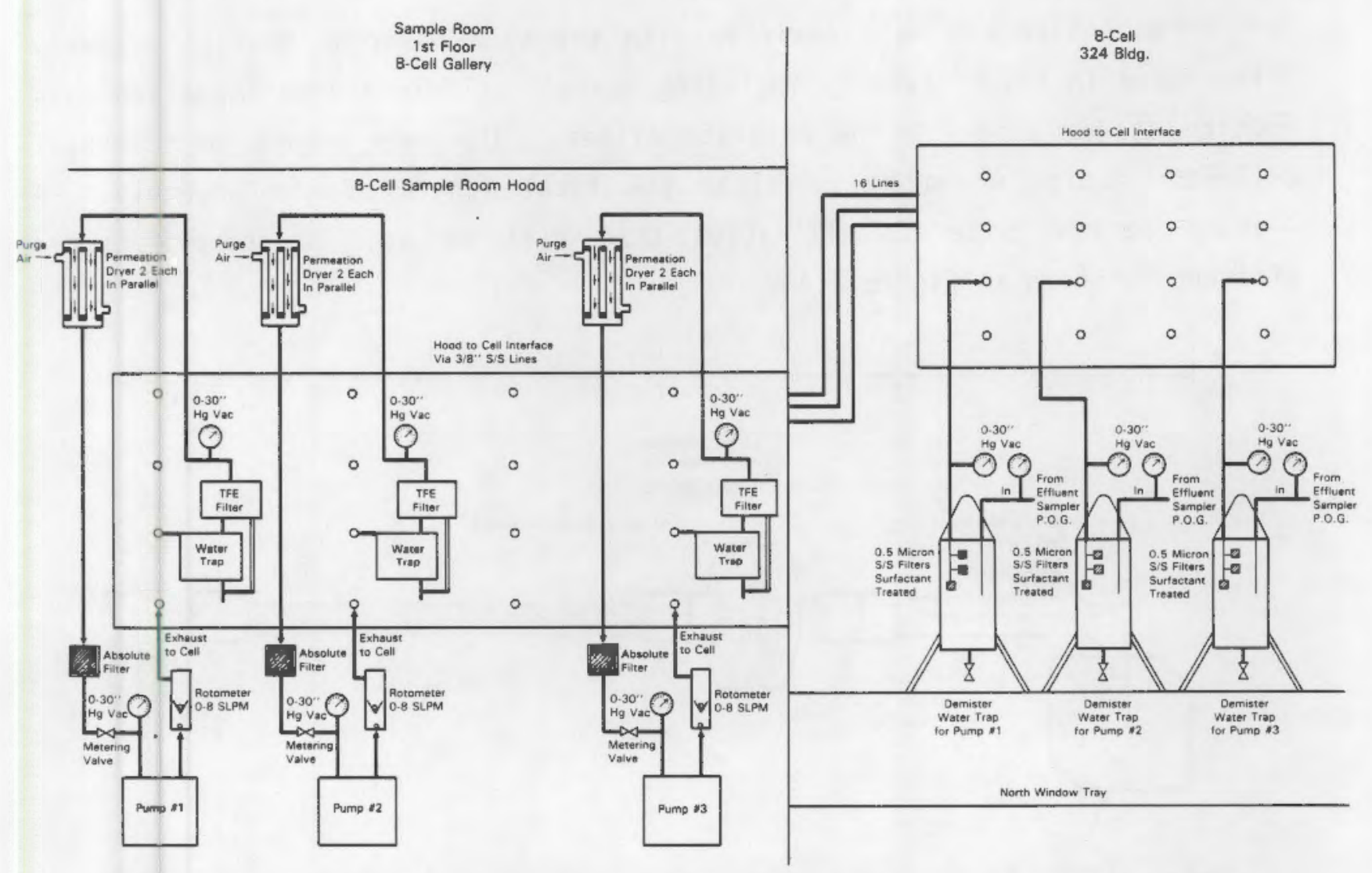

FIGURE 4.38. Components for the RLFCM off-Gas Sample Control system 
The function of the effluent collection equipment to be used with these three sample control loops is to collect aerosols and to condense and/or scrub out gaseous effluent. All sample systems will, therefore, be composed of an absolute filtration device followed by a condenser and/or gas scrubber. The condensation step is required only when the unquenched melter off-gas stream is sampled. Gas scrubbing will always be employed irrespective of the sampling site. Figure 4.39 is a schematic of a typical aerosol collection device that is a heated absolute filter equipped with an appropriate POG connector, a heated sample delivery tube and remotized quick disconnects for joining the filter assembly to the sample delivery system and to the downstream condenser and/or gas scrubber subassembly. The POG connector used with this filter assembly is determined by the sampling site to be used, the manipulative support available, and the desire to minimize sample biasing affects. The block connector allows samples to be extracted from standard rack face junctions.

Aerosol size can be classified with the same basic filtration assembly illustrated in Figure 4.39 by including heated cyclonic and/or impaction collection stages prior to the absolute filter. The only impact upon aerosol collector design would be to alter the total length of the assembly. A 4-stage aerosol size classification that will be used to sample melter effluent is shown in Figure 4.40 .

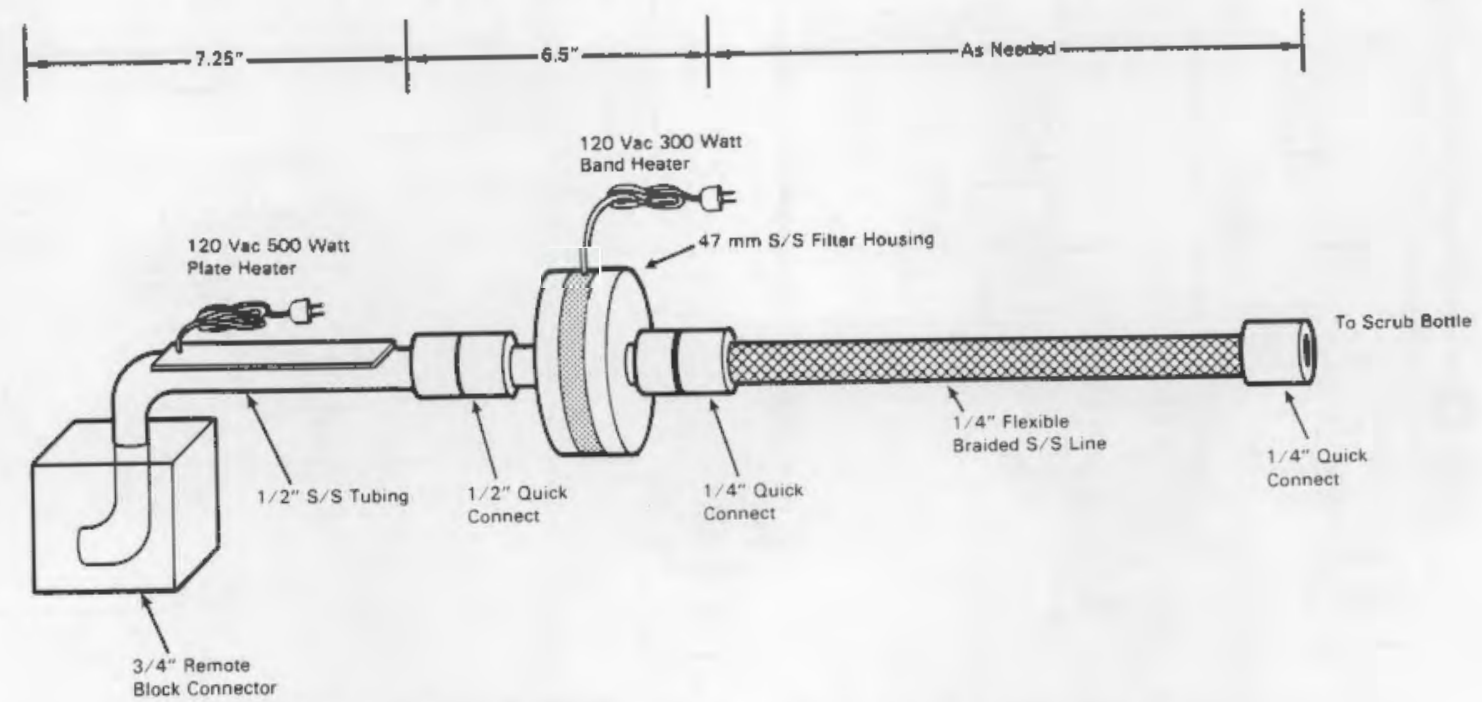

FIGURE 4.39. Typical Aerosol Collection Device 


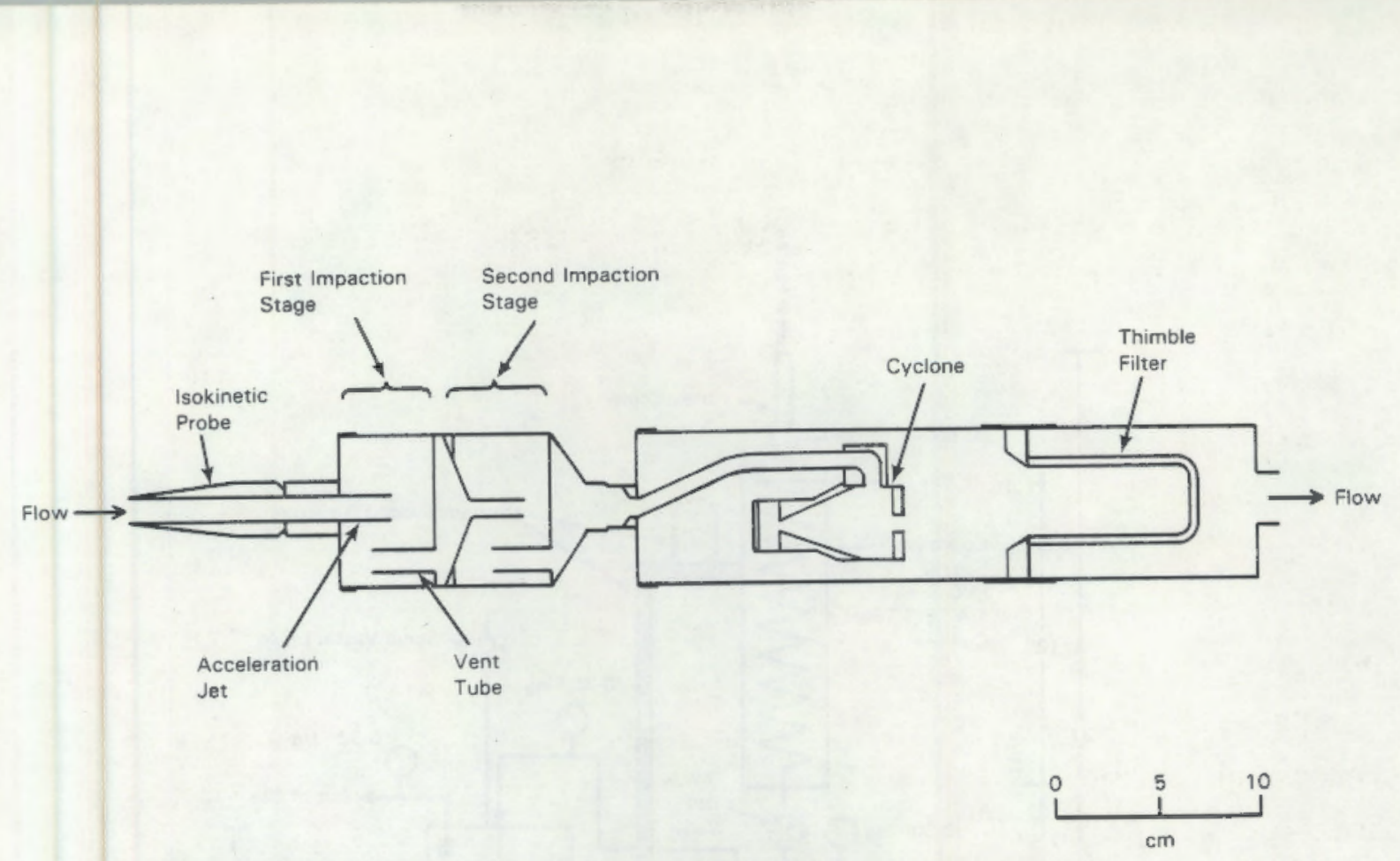

FIGURE 4.40. Four-Stage Aerosol Size Classification Device

Once aerosols have been removed from the sampling stream, the stream must be cooled, if not previously quenched, and scrubbed to remove gaseous effluents. The design of the sample stream quench-scrubber is illustrated in Figure 4.41. The system is composed of a refrigerated, air-cooled condenser, a condensated receiver and a gas scrubbing vessel. The use of surfactant treated stainless steel filters obviate the need for system valving while eliminating the potential for liquid sample loss or vessel liquor intermixing under all anticipated handling conditions. The use of forced vortex air refrigeration as the condenser heat exchange media also el iminates cooling water and the need to deal with it as a waste stream. The vortex coolers possess no moving parts, require only $80 \mathrm{psi}$ instrument air, and have sufficient capacity to handle unquenched process off-gas sampling streams. Gas scrubbing is provided by gas dispersion through appropriate scrubbing 1 iquid. Additional scrubbing action can be added to this quench scrubber system by cascading additional gas scrubber stages. The design of these scrubbers is illustrated in Figure 4.42. For sampling quenched off-gases, the gas scrubber as shown in Figure 4.42 will be used. 


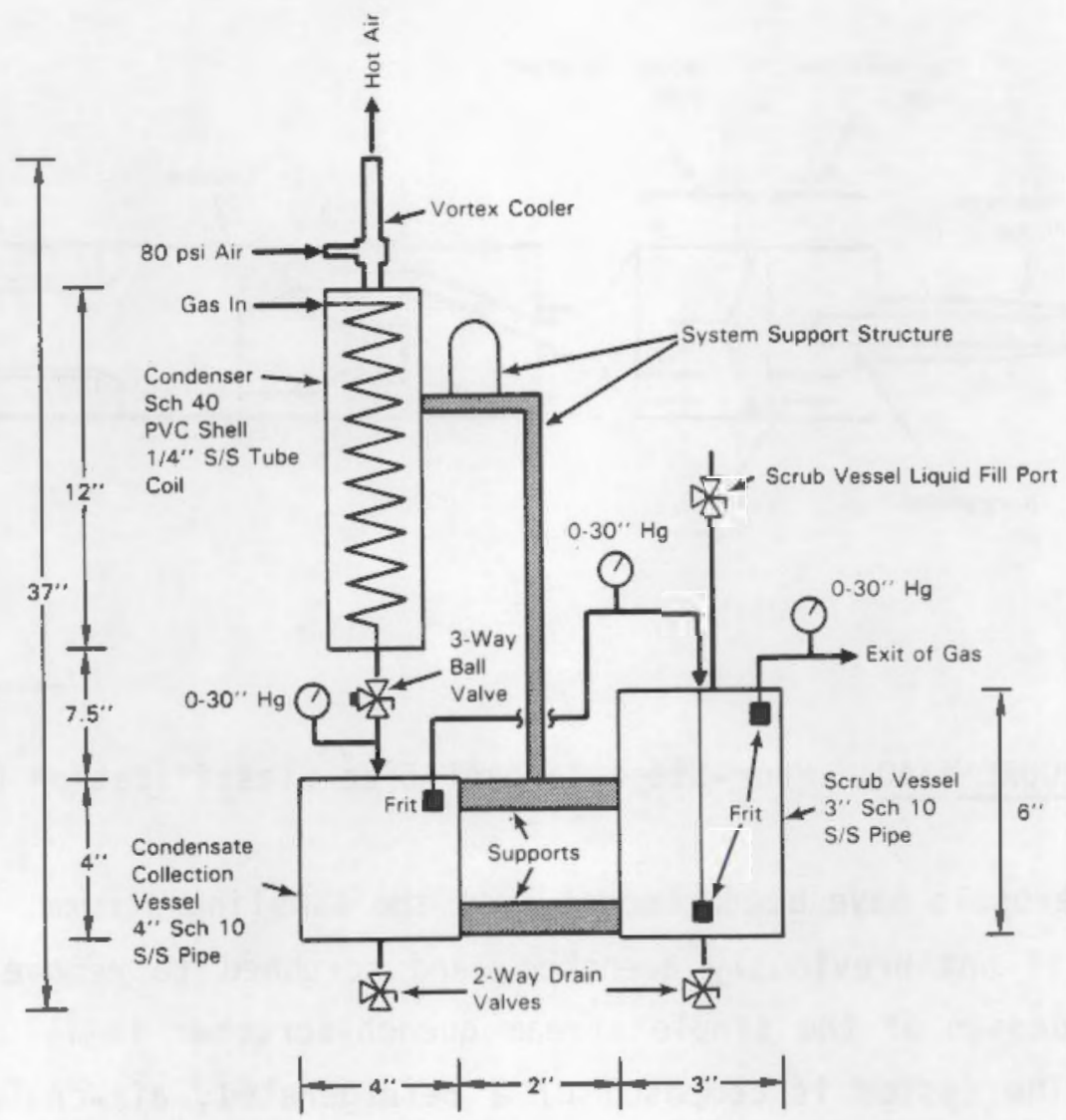

FIGURE 4.41. RLFCM Quench-Scrubber

The sample fractions generated by the various components of the total off-gas effluent sampler will be transferred from B-Cell to the 325 building hot cells where radiochemical separations and analysis will be performed. The results of these sample analyses will form the basis for characterizing RLFCM behavior and establish off-gas system performance. 


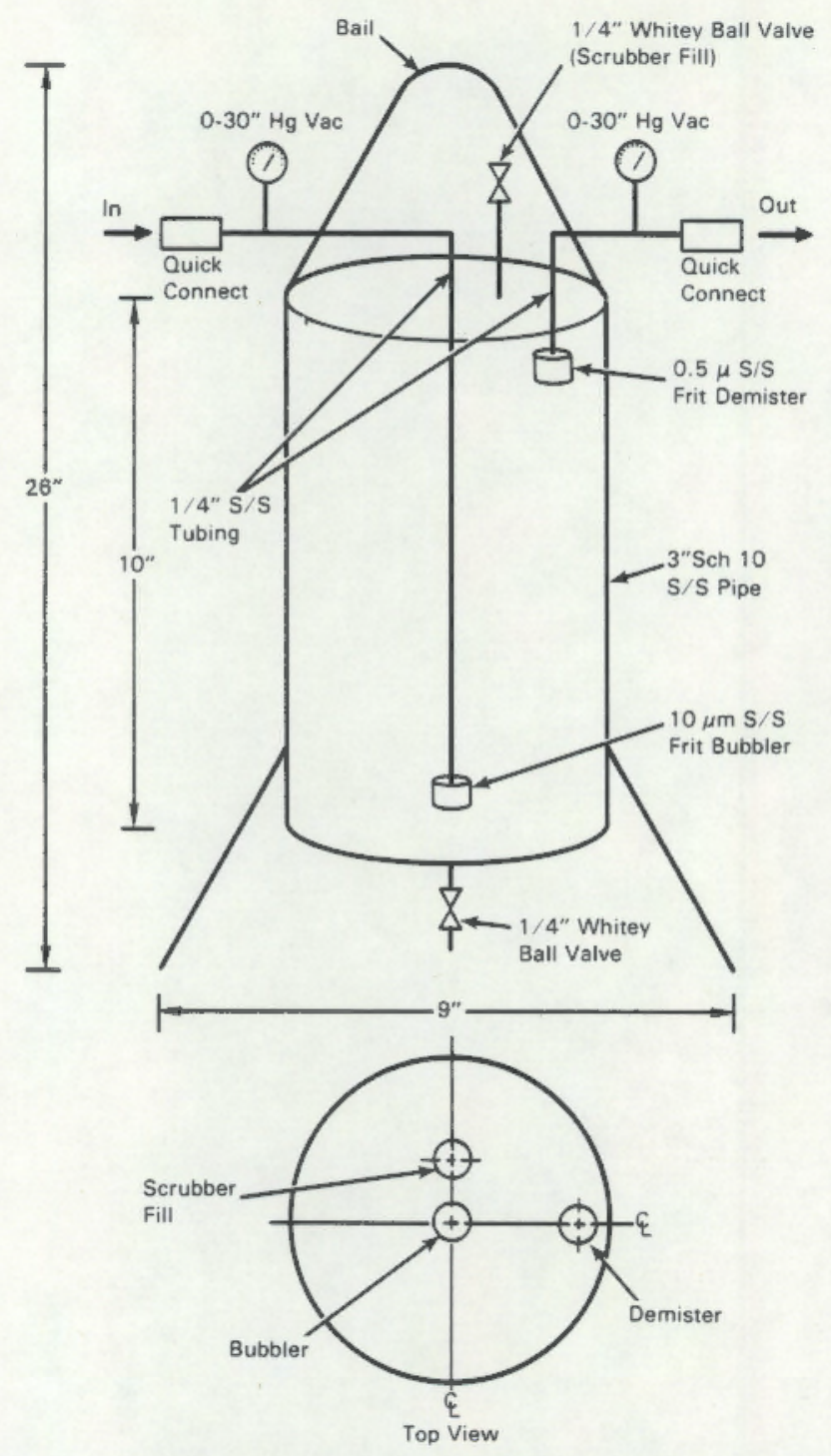

FIGURE 4.42. Effluent Scrubber for Cold Stream Sampling 



\subsection{REFERENCES}

Barnes, S. M., and D. E. Larson. 1981. Materials and Design Experience in a Slurry-Fed Electric Glass Melter. PNL-3959, Pacific Northwest Laboratory, Richland, WA.

Bird, R. B., H. E. Stewart, and E. N. Lightfoot. 1960. Transport Phenomena, p. 60, John Wiley and Sons, Inc., New York, NY.

Chapman, C. C., et al. 1979. Vitrification of Hanford hastes in a jouleHeated Ceramic Melter, and Evaluation of Resultant Canisterized Product. PNL-2904, Pacific Northwest Laboratory, Richland, WA.

Goles, R. H., and G. J. Sevigny. 1982. "Off-Gas Characteristics of Liquid-Fed Joule-Heated Ceramic Melters," In proceedings of the 17th DOE Air Cleaning Conference, Denver Co.

Hanson, M. S., and W. J. Bjorklund. 1980. Vitrification of Radioactive HighLevel Waste by Spray Calcination and In-Can Melting. PNL-3155, Pacific Northwest Laboratory, Richland, WA.

MCEl roy, J. L., et al. 1972. "Waste Solidification Program Summary Report." Vol. Il of Evaluation of WSEP High-Level Waste Solidification Processes. BNWL-1667, Pacific Northwest Laboratory, Richland, WA.

Schneider, K. J., and V. P. Kelley. 1969. Waste Solidification Program, Vol. $X I$, Design Features of the waste Solidification Engineering Prototype. BNWL-968, Pacific Northwest Laboratory, Richland, WA.

Wheelwright, E. J., et al. 1979. Technical Summary, Nuclear Waste Vitrification Project. PNL-3038, Pacific Northwest Laboratory, Richland, WA. 


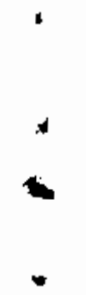




\subsection{GLOSSARY}

$\begin{array}{ll}\text { ASME } & \text { American Society of Mechanical Engineers } \\ \text { AZS } & \text { alumina-zirconia-silica } \\ \text { CSCl } & \text { cesium chloride } \\ \text { DOF } & \text { Department of Energy } \\ \text { DWPF } & \text { Defense Waste Processing Facility } \\ \text { EPA } & \text { Fnvironmental Protection Agency } \\ \text { HFPA } & \text { high efficiency particulate air (filter) } \\ \text { HLLW } & \text { high-level liquid waste } \\ \text { HLW } & \text { high-level waste } \\ \text { HWVP } & \text { Hanford baste Vitrification Project } \\ \text { IRC } & \text { inner refractory cooler } \\ \text { LWR } & \text { light water reactor } \\ \text { NRC } & \text { Nuclear Regulatory Commission } \\ \text { NWTP } & \text { Nuclear Waste Treatment Program } \\ \text { NWVP } & \text { Nuclear Waste Vitrification Project } \\ \text { OBE } & \text { operating basis earthquake } \\ \text { PNL } & \text { Pacific Northwest Laboratory } \\ \text { POG } & \text { process off gas } \\ \text { PSCM } & \text { pilot scale ceramic melter } \\ \text { PUREX } & \text { plutonium and uranium extraction } \\ \text { RAM } & \text { radiation area monitors } \\ \text { RLFCM } & \text { radioactive liquid-fed ceramic melter } \\ \text { SC/ICM } & \text { spray calciner/in-can melter } \\ \text { SCR } & \text { silicon controlled rectifier } \\ \text { SRC } & \text { subrefractory cooler } \\ \text { SS } & \text { stainless steel } \\ \text { TRU } & \text { transuranic } \\ \text { WSEP } & \text { waste solidification engineering prototypes } \\ \text { WVDP } & \text { West Valley Demonstration Project } \\ & \end{array}$




\section{OISTRIBUTION}

No. of

Copies

OFFSITE

30 DOE Technical Information Center

DOE West Valley Operations Office

P.0. Box 191

West Valley, NY 14171

ATTN: W. H. Hannum

2 DOE Idaho Operations Office

550 Second Street

Idaho Falls, ID 83401

ATTN: J. D. Hamric

J. B. Whitsett

3 DOE Office of Terminal Waste

Disposal \& Remedial Action

GTN

Washington, DC 20545

ATTN: 3. A. Coleman, NE-25

J. A. Turi, NE-25

J. B. Zorn, NE-25

DOE Savannah River Operations

Cffice

P.D. Box A

Aiken, SC 29801

ATTN: G. K. Derte1

2 Argonne National Laboratory

9700 South Cass Avenue

Argonne, IL 60439

ATTN: C. S. Abrams/J. H. Kittel

M. J. Steindler/

L. E. Trevorrow

Sandia Laboratories

P.0. Box 5800

Albuquerque, NM 87185

ATTN: $w$. Weart
No. of

Copies

Westinghouse Idaho Nuclear

Co., Inc.

P.0. Box 4000

Idaho Falls, I0 83401

ATTN: B. R. Wheeler

2 E. I. du Pont de Nemours Company

Savannah River Laboratory

Aiken, SC 29801

ATTN: R. G. Baxter

M. O. Boersma

Battelle Memorial Institute

505 King Avenue

Columbus, OH 43201

ATTN: B. Rawles

Electric Power Research Institute

3412 Hillview Avenue

P.0. Box 10412

Palo Alto, CA 94304

ATTN: R. Williams

5 West Valley Nuclear Services Company

P.0. Box 191

West Valley, NY 14171

ATTN: J. L. Knabenschuh

ONSITE

3 DOE Richland Operations Office

E. A. Bracken

M. J. Plahuta

M. W. Shupe 
No. of

Copies

5 Rockwell Hanford Operations

K. A. Gasper

R. N. Gurley

R. D. Prosser

K. R. Shah

R. J. Thompson

UNC United Nuclear Industries

T. E. Dabrowski/W. J. Kyriazis

1 Westinghouse Hanford Company

R. E. Lerch $/ J$. D. Watrous

50 Pacific Northwest Laboratory

D. N. Berger

W. J. Bjorklund (5)

H. T. Blair/J. M. Perez

W. F. Bonner/M. S. Hanson

R. A. Brouns

G. H. Bryan

H. C. Burkholder/J. H. Jarrett
No. of

Copies

T. D. Chikalla

R. D. Dierks

R. M. Gale

R. W. Goles (2)

P. J. Hof

L. K. Holton, Jr. (10)

R. M. Jones

D. E. Knowlton/J. R. Carrell

D. E. Larson

J. M. Latkovich

R. C. Liikala

R. P. Marshall/D. B. Cearlock

J. L. McElroy

J. E. Minor

D. R. Montgomery

A. M. Platt/R. E. Nightingale

N. L. Scharnhorst

G. J. Sevigny

N. M. Sherer

D. H. Siemens

N. M. Thomas

J. H. Westsik, Jr. Technical Information (5)

Publishing Coordination (2) 